\title{
External Peer Review Team Report Underground Testing Area Subproject for Frenchman Flat
}

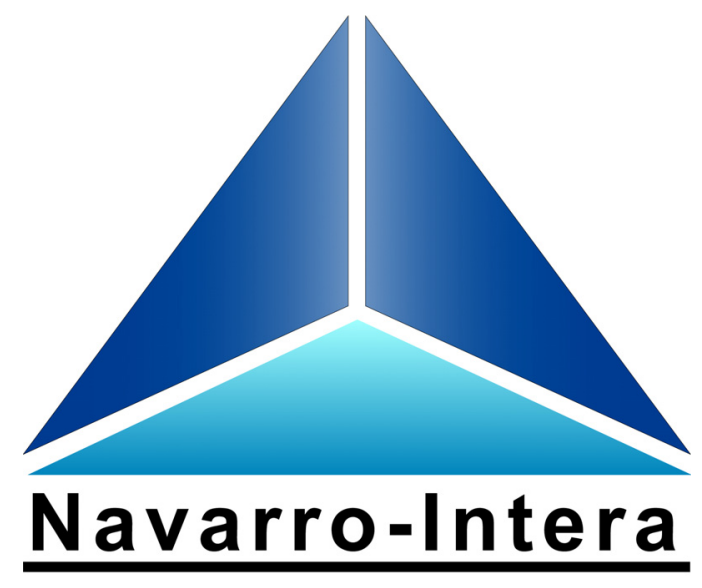

Revision No.: 1

September 2010

Prepared for U.S. Department of Energy under Contract No. DE-AC52-09NA28091. 
Available for sale to the public from:

U.S. Department of Commerce

National Technical Information Service

5301 Shawnee Road

Alexandria, VA 22312

Telephone: 800.553 .6847

Fax: 703.605.6900

E-mail: orders@ntis.gov

Online Ordering: http://www.ntis.gov/help/ordermethods.aspx

Available electronically at http://www.osti.gov/bridge

Available for a processing fee to U.S. Department of Energy and its contractors, in paper, from:

U.S. Department of Energy

Office of Scientific and Technical Information

P.O. Box 62

Oak Ridge, TN 37831-0062

Phone: 865.576.8401

Fax: 865.576.5728

Email: reports@adonis.osti.gov

Reference herein to any specific commercial product, process, or service by trade name, trademark, manufacturer, or otherwise, does not necessarily constitute or imply its endorsement, recommendation, or favoring by the United States Government or any agency thereof or its contractors or subcontractors. 


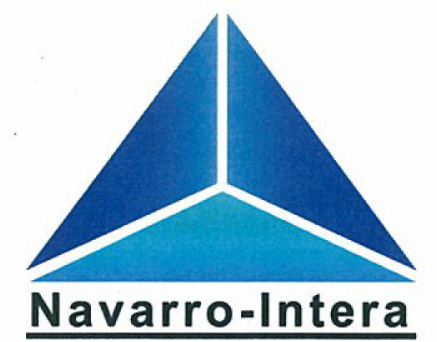

\section{EXTERNAL PEER REVIEW TEAM REPORT UNDERGROUND TESTING AREA SUBPROJECT FOR FRENCHMAN FLAT}

Revision No.: 1

September 2010

Navarro-Intera, LLC

c/o U.S. DOE

P.O. Box 98952

Las Vegas, NV 89193-8952

Reviewed and determined to be UNCLASSIFIED.
Derivative Classifier: $\frac{\text { Joseph P. Johnston/N-I CO }}{\text { (Name/personal identifier andwosition title) }}$
Signature: $\frac{\text { /s / Joseph P. Johnston }}{09 / 28 / 2010}$
Date:

Prepared for U.S. Department of Energy under Contract No. DE-AC52-09NA28091.

Approved for public release; further distribution is authorized. 


\section{EXTERNAL PEER REVIEW TEAM REPORT \\ UNDERGROUND TESTING AREA SUBPROJECT FOR FRENCHMAN FLAT}




\section{TABLE OF CONTENTS}

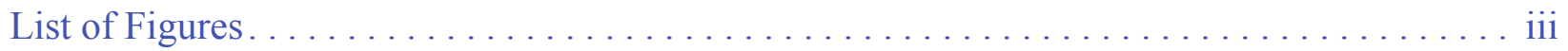

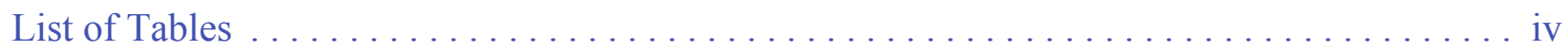

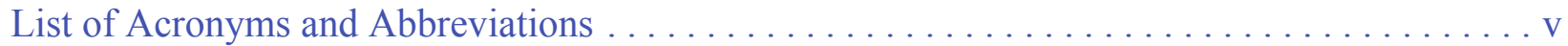

Executive Summary . . . . . . . . . . . . . . . . . . . . . . . . . . .

$1.0 \quad$ Introduction. . . . . . . . . . . . . . . . . .

$2.0 \quad$ Background. . . . . . . . . . . . . . . . . . .

$2.1 \quad$ Radionuclides ............................. 2-3

2.2 Contaminant Boundaries. . . . . . . . . . . . . . . . . . . .

$3.0 \quad$ Observational Data . . . . . . . . . . . . . . . . . . . . . . . . .

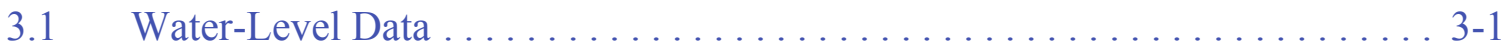

3.2 Water-Quality Data. . . . . . . . . . . . . . . . . . . 3-10

3.2.1 Groundwater Age . . . . . . . . . . . . . . . . . . . . . . . . 3-10

3.2.2 Groundwater Quality Characteristics . . . . . . . . . . . . . 3-12

3.2.3 Use of Groundwater Age in NHA Model. . . . . . . . . . . . . . . . . 3-14

3.3 Permeability Data . . . . . . . . . . . . . . . . . . . . 3-17

3.4 Geologic Data and Hydrostratigraphic Framework Model . . . . . . . . . . . 3-19

3.5 Groundwater Budget Synthesis . . . . . . . . . . . . . . . 3-23

4.0 Use of Models as Regulatory Decision Tools . . . . . . . . . . . . . . . . . . 4-1

4.1 Definition of Model Purpose $\ldots \ldots \ldots \ldots \ldots \ldots \ldots \ldots \ldots \ldots \ldots \ldots \ldots \ldots \ldots$

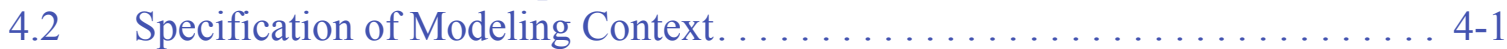

4.3 Conceptual Model Formulation . . . . . . . . . . . . . . . . 4-2

4.4 Computational Model Development. . . . . . . . . . . . . . . 4-2

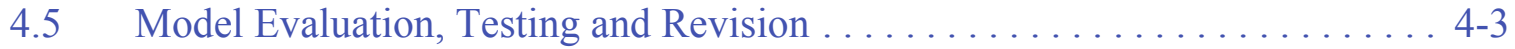

4.6 Model Use in Regulatory Context . . . . . . . . . . . . . . . . . . . . . 4-4

$5.0 \quad \begin{aligned} & \text { Are Modeling Approaches, Assumptions, } \\ & \text { and Results Consistent with Regulatory Use? } \ldots \ldots \ldots \ldots \ldots \ldots \ldots \ldots \ldots \ldots\end{aligned}$

$5.1 \quad$ Modeling Approaches. . . . . . . . . . . . . . . . . . . . . . . . . 5-1

$5.2 \quad$ Model Assumptions . . . . . . . . . . . . . . . . . . . . . . . 5-5

5.3 Model Results . . . . . . . . . . . . . . . . . . . . . .

6.0 Do Modeling Results Adequately Account for Uncertainty? . . . . . . . . . . . . . .

7.0 Are Modeling Results Adequate To Move

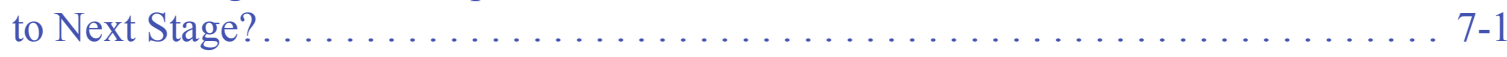

$8.0 \quad$ Static Analyses . . . . . . . . . . . . . . . . . . . . . . . 8-1

$8.1 \quad$ Climate Change. . . . . . . . . . . . . . . . . . . . . . . . . . 8-1

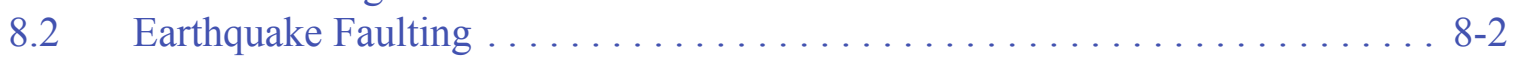




\section{TABLE OF CONTENTS (CONTINUED)}

9.0 Recommendations.................................. 9-1

9.1 Recommendations on Monitoring in Next Stage .................. 9-1

9.2 Recommendations on Water-Level Monitoring.................... 9-2

9.3 Recommendations on Model Development ...................... 9-2

9.4 Recommendations on Model Complexity .................... 9-3

10.0 Documents Reviewed and Other References . . . . . . . . . . . . . . . . . . . . . . . 10-1

Appendix A - Bibliographic Information on Peer Review Team Members

A.1.0 Bibliographic Information on Peer Review Team Members . . . . . . . . . . . . . . A-1

Appendix B - Agenda for April 6-9, 2010, Meeting in Las Vegas 


\section{LIST OF FIGURES}

NUMBER

TITLE

PAGE

2-1 Surficial Geologic Map of Frenchman Flat and Vicinity. . . . . . . . . . . . 2-2

2-2 Geologic Map at Water Table, Frenchman Flat and Vicinity . . . . . . . . . . . 2-4

2-3 Calculated Contaminant Boundaries, Northern Testing Area . . . . . . . . . . . . . 2-9

2-4 Calculated Contaminant Boundaries, Central Testing Area. . . . . . . . . . . . . 2-10

3-1 Water Levels in Water-Table Wells, Northern Testing Area. . . . . . . . . . . . . . 3-2

3-2 Model Calculated Rates and Direction of Groundwater Flow, UE-5 PW-2 to UE-5 PW-1 . . . . . . . . . . . . . . . . . . . . . . . . . 3-4

3-3 Water Levels in Pilot Wells . . . . . . . . . . . . . . . . . . . 3-5

3-4 Direction and Rate of Flow at Pilot Wells . . . . . . . . . . . . . . 3-6

3-5 Water Levels in Water-Table Wells, Frenchman Flat . . . . . . . . . . . . . . . 3-8

3-6 Measured Water Levels in Water Supply Wells WW-5B and WW-5C ... . . . . 3-9

3-7 Groundwater Age, Frenchman Flat and CP Basin . . . . . . . . . . . . . 3-11

3-8 Sodium and Calcium Concentrations in Groundwater, Frenchman Flat . . . . . . . 3 3-13

3-9 Chloride Concentrations in Groundwater, Frenchman Flat . . . . . . . . . . . . 3-15

3-10 Groundwater Directions and Velocities as Calculated from Groundwater Age . . . 3-16

3-11 Conceptual Model of Groundwater Flow in Frenchman Flat . . . . . . . . . . . . . . 3-24

5-1 Relationship between Various Flow and Transport Models

Developed for Frenchman Flat. . . . . . . . . . . . . . . . . . . 5-2

8-1 Late Quaternary Fault Map of the NNSS . . . . . . . . . . . . . $8-4$

8-2 Gutenberg-Richter Plot of the Observed Rate of Earthquake

Occurrence in the NNSS Region . . . . . . . . . . . . . . . . 


\section{LIST OF TABLES}

NUMBER

2-1 Radionuclide Inventory Uncertainty . . . . . . . . . . . . . . . . . 2-6

2-2 Calculated Contaminant Boundary Dimensions . . . . . . . . . . . . . . . . 2-7

2-3 Summary of Flow and Transport Realizations $\ldots \ldots \ldots \ldots \ldots \ldots \ldots \ldots . \ldots 211$

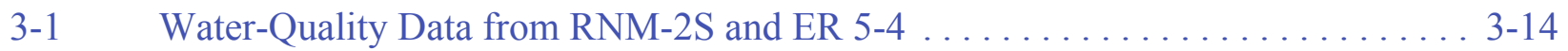




\section{LIST OF ACRONYMS AND ABBREVIATIONS}

\begin{tabular}{|c|c|}
\hline $3-\mathrm{D}$ & Three-dimensional \\
\hline $\mathrm{AA}, \mathrm{AA} 1, \mathrm{AA} 2$ & Alluvial aquifer \\
\hline Am & Americium \\
\hline amsl & Above mean sea level \\
\hline ASTM & American Society for Testing and Materials \\
\hline $\mathrm{BC}$ & Boundary condition \\
\hline BLFA & Basalt lava-flow aquifer alternative HFM \\
\hline $\mathrm{BN}$ & Bechtel Nevada \\
\hline $\mathrm{C}$ & Carbon \\
\hline $\mathrm{Ca}$ & Calcium \\
\hline CADD & Corrective action decision document \\
\hline CAI & Corrective action investigation \\
\hline CAIP & Corrective action investigation plan \\
\hline CAP & Corrective action plan \\
\hline CAU & Corrective action unit \\
\hline $\mathrm{Cl}$ & Chlorine \\
\hline $\mathrm{Cm}$ & Curium \\
\hline $\mathrm{cm} / \mathrm{yr}$ & Centimeters per year \\
\hline CPBA & $\mathrm{CP}$ thrust fault alternative HFM \\
\hline $\mathrm{CR}$ & Closure report \\
\hline Cs & Cesium \\
\hline DISP & Displacement fault (aquifer juxtaposition) alternative HFM \\
\hline DOE & U.S. Department of Energy \\
\hline EPA & U.S. Environmental Protection Agency \\
\hline FFACO & Federal Facility Agreement and Consent Order \\
\hline $\mathrm{ft}$ & Foot \\
\hline${ }^{3} \mathrm{H}$ & Tritium \\
\hline HFM & Hydrostratigraphic framework model \\
\hline HST & Hydrologic source term \\
\hline I & Iodine \\
\hline in./yr & Inches per year \\
\hline $\mathrm{K}_{\mathrm{d}}$ & Distribution coefficient \\
\hline $\mathrm{km}$ & Kilometer \\
\hline LCA & Lower carbonate aquifer \\
\hline
\end{tabular}




\section{LIST OF ACRONYMS AND ABbREVIATIONS (CONTINUED)}

LCA3 Lower carbonate aquifer-thrust plate

LCCU Lower clastic confining unit

LTCU, LTCU1 Lower tuff confining unit

LVTA Lower vitric-tuff aquifer

m Meter

$\mathrm{m} / \mathrm{d} \quad$ Meters per day

$\mathrm{m} / \mathrm{s} \quad$ Meters per second

$\mathrm{m} / \mathrm{yr} \quad$ Meters per year

$\mathrm{m} / 100 \mathrm{yr} \quad$ Meters per 100 years

$\mathrm{m} / 1,000 \mathrm{yr} \quad$ Meters per 1,000 years

$\mathrm{mg} / \mathrm{L} \quad$ Milligrams per liter

NAD North American Datum

NDEP Nevada Division of Environmental Protection

NHA Northern Hydrologic Alternative

NNES Navarro Nevada Environmental Services, LLC

NNSA/NSO U.S. Department of Energy, National Nuclear Security Administration Nevada Site Office

NNSS Nevada National Security Site

NRC National Research Council

NSMC Null Space Monte Carlo

NTS Nevada Test Site

OAA, OAA1 Older alluvial aquifer

PCU1L, PCU1U Older playa confining unit

PCU2T Playa confining unit

PSHA Probabilistic Seismic Hazard Analysis

$\mathrm{Pu} \quad$ Plutonium

RMC Reactive mineral category

RNM Radionuclide migration

RWMS Radioactive waste management site

SNJV Stoller-Navarro Joint Venture

$\mathrm{Sr} \quad$ Strontium

SSM Simplified source term model

Tc Technetium

$\mathrm{TcO}_{2} \quad$ Technetium oxide

$\mathrm{TcO}_{4}^{-} \quad$ Pertechnetate 


\section{LIST OF ACRONYMS AND ABBREVIATIONS (CONTINUED)}

TM-LVTA

TM-WTA

TSA

$\mathrm{UCCU}$

UGTA

USGS

USGSD

UTCU

UTM

VCU

WCU

WIPP

WW

$\mathrm{Xe}$

\author{
Timber Mountain lower vitric-tuff aquifer \\ Timber Mountain welded-tuff aquifer \\ Topopah Spring aquifer \\ Upper clastic confining unit \\ Underground Test Area \\ U.S. Geological Survey \\ U.S. Geological Survey Distributed Recharge Map \\ Upper tuff confining unit \\ Universal Transverse Mercator \\ Volcaniclastic confining unit \\ Wahmonie confining unit \\ Waste Isolation Pilot Plant \\ Water Well \\ Xenon
}




\section{EXECUTIVE SUMMARY}

An external peer review was conducted to review the groundwater models used in the corrective action investigation stage of the Underground Test Area (UGTA) subproject to forecast zones of potential contamination in 1,000 years for the Frenchman Flat area. The goal of the external peer review was to provide technical evaluation of the studies and to assist in assessing the readiness of the UGTA subproject to progress to monitoring activities for further model evaluation. The external peer review team consisted of six independent technical experts with expertise in geology, hydrogeology, groundwater modeling, and radiochemistry.

The peer review team was tasked with addressing the following questions:

1. Are the modeling approaches, assumptions, and model results for Frenchman Flat consistent with the use of modeling studies as a decision tool for resolution of environmental and regulatory requirements?

2. Do the modeling results adequately account for uncertainty in models of flow and transport in the Frenchman Flat hydrological setting?

a. Are the models of sufficient scale/resolution to adequately predict contaminant transport in the Frenchman Flat setting?

b. Have all key processes been included in the model?

c. Are the methods used to forecast contaminant boundaries from the transport modeling studies reasonable and appropriate?

d. Are the assessments of uncertainty technically sound and consistent with state-of-the-art approaches currently used in the hydrological sciences?

3. Are the datasets and modeling results adequate for a transition to Corrective Action Unit monitoring studies - the next stage in the UGTA strategy for Frenchman Flat?

The peer review team is of the opinion that, with some limitations, the modeling approaches, assumptions, and model results are consistent with the use of modeling studies for resolution of environmental and regulatory requirements. The peer review team further finds that the modeling studies have accounted for uncertainty in models of flow and transport in the Frenchman Flat except for a few deficiencies described in the report. Finally, the peer review team concludes that the UGTA 
subproject has explored a wide range of variations in assumptions, methods, and data, and should proceed to the next stage with an emphasis on monitoring studies.

The corrective action strategy, as described in the Federal Facility Agreement and Consent Order, states that the groundwater flow and transport models for each corrective action unit will consider, at a minimum, the following:

- Alternative hydrostratigraphic framework models of the modeling domain.

- Uncertainty in the radiological and hydrological source terms.

- Alternative models of recharge.

- Alternative boundary conditions and groundwater flows.

- Multiple permissive sets of calibrated flow models.

- Probabilistic simulations of transport using plausible sets of alternative framework and recharge models, and boundary and groundwater flows from calibrated flow models.

- Ensembles of forecasts of contaminant boundaries.

- Sensitivity and uncertainty analyses of model outputs.

The peer review team finds that these minimum requirements have been met. The team notes that the sophistication and complexity of the modeling evaluations that have been conducted are state-of-the-practice analyses that go far beyond those conducted at other contaminated sites in the United States. The peer review team is of the opinion that potential processes that could affect the migration of radionuclides in groundwater have been thoroughly evaluated.

To understand groundwater flow and transport, it is critical to develop an understanding of the geologic setting of the groundwater system. The geologic setting of Frenchman Flat is complex, involving multiple episodes of deformation culminating in the Basin and Range normal and normal-oblique faulting responsible for the modern physiography. The peer review team finds that the understanding of the geologic setting that has been developed is technically sound, and that appropriate methods have been used to constrain the subsurface geology and structure. The geologic investigations have been overseen by a team of project scientists that impressed the peer review team 
with their detailed knowledge of the regional and local geologic setting, and their utilization of a variety of information - including detailed cuttings analysis, down-hole logs, and multiple types of geophysical data — to guide their interpretation of the subsurface.

While the groundwater modeling and uncertainty analyses have been quite detailed, the peer review team has identified several modeling-related issues that should be addressed in the next phase of the corrective action activities:

- Evaluating and using water-level gradients from the pilot wells at the Area 5 Radioactive Waste Management Site in model calibration.

- Re-evaluating the use of geochemical age-dating data to constrain model calibrations.

- Developing water budgets for the alluvial and upper volcanic aquifer systems in Frenchman Flat.

- Considering modeling approaches in which calculated groundwater flow directions near the water table are not predetermined by model boundary conditions and areas of recharge, all of which are very uncertain.

- Evaluating local-scale variations in hydraulic conductivity on the calculated contaminant boundaries.

- Evaluating the effects of non-steady-state flow conditions on calculated contaminant boundaries, including the effects of long-term declines in water levels, climatic change, and disruption of groundwater system by potential earthquake faulting along either of the two major controlling fault zones in the flow system (the Cane Spring and Rock Valley faults).

- Considering the use of less-complex modeling approaches.

- Evaluating the large change in water levels in the vicinity of the Frenchman Flat playa and developing a conceptual model to explain these water-level changes.

- Developing a long-term groundwater level monitoring program for Frenchman Flat with regular monitoring of water levels at key monitoring wells.

The peer review team is of the opinion that the sophistication and complexity of the groundwater models used to calculate the contaminant boundaries are inconsistent with the sparseness of the available hydrogeologic data in Frenchman Flat and that the models likely understate the uncertainty in some aspects of the groundwater conditions. The peer review team is also of the opinion that 
calculated contaminant boundaries are presented in an aura of complexity and technical sophistication that provides a false sense of confidence in the model predictions. For example, some of the calculated contaminant boundaries are not even consistent with the flow directions estimated from the observed data in nearby wells at present time. How good could they be as a predictor of future conditions 1,000 years from now?

Despite these reservations, the peer review team strongly believes that the UGTA subproject should proceed to the next stage. It is the opinion of the peer review team that the sophistication and complexity of numerical modeling at Frenchman Flat has far exceeded the availability and quality of observational data. Despite the sophistication and precision of the numerical modeling, a great deal of uncertainty is inherent for modeling and predicting radionuclide migration in 1,000 years at Frenchman Flat. The peer review team, therefore, recommends that greater emphasis be placed on monitoring and data collection, that careful scoping analyses of the monitoring data be conducted to assess future numerical modeling, and that the proposed adaptive management strategy be adopted to ensure protection of the public against exposure to radioactive contaminants from the nuclide test sites at Frenchman Flat. 


\subsection{INTRODUCTION}

The Nevada National Security Site (NNSS) (formerly the Nevada Test Site [NTS]), located in southern Nevada, was the primary site used in the United States for underground testing of nuclear weapons. Underground testing in deep vertical shafts and tunnels was conducted at the NTS from 1951 to 1992. Between 1965 and 1971, 10 underground nuclear tests were conducted at Frenchman Flat, the subject of this report. Seven tests were detonated in the Northern Testing Area, and three were detonated in the Central Testing Area. All 10 tests were exploded at the bottom of drilled vertical holes and mined shafts.

The U.S. Department of Energy (DOE) initiated the Underground Test Area (UGTA) subproject to assess and evaluate radiologic groundwater contamination resulting from underground nuclear test at the NTS and vicinity. For Frenchman Flat, the UGTA subproject addresses media contaminated by the underground nuclear tests, which is limited to geologic formations within the saturated zone or to 100 meters (m) or less above the water table, and media contaminated by the well used for a radionuclide migration experiment (RNM-2S). Groundwater transport has been judged to be the primary mechanism of migration for the subsurface contamination away from the Frenchman Flat underground nuclear tests.

The goal of the UGTA subproject is to assess the public risk from groundwater contaminated as the result of nuclear testing. The primary method to assess this risk is the development of models of groundwater flow and radionuclide transport and using these models to forecast the potential extent of contaminated groundwater for the next 1,000 years. Contaminated groundwater is defined for this project as groundwater that exceeds the radiological standards of the Safe Drinking Water Act (CFR, 2009).

Model forecasts will provide the basis for negotiating a compliance boundary for the Frenchman Flat Corrective Action Unit (CAU). This compliance boundary represents a regulatory-based distinction between groundwater contaminated or not contaminated by underground testing. The compliance 
boundary for Frenchman Flat will be negotiated between the Nevada Division of Environmental Protection (NDEP) and the DOE National Nuclear Security Administration Nevada Site Office (NNSA/NSO). The starting point for the negotiations will be a modeling forecast that provides an estimate of the three-dimensional (3-D) volume of groundwater that is likely to be contaminated as a result of the nuclear testing at Frenchman Flat within the next 1,000 years. The perimeter of this volume of groundwater is referred to as the "contaminant boundary."

The corrective action strategy for the Frenchman Flat CAU follows a four-step process described in the Federal Facility Agreement and Consent Order (FFACO) (1996, as amended March 2010):

1. The Corrective Action Investigation Plan (CAIP) stage

2. The Corrective Action Investigation (CAI) stage

3. The Corrective Action Decision Document (CADD)/Corrective Action Plan (CAP) stage

4. The Closure Report (CR) stage

The final step in the CAI stage is a decision point as to whether or not the modeling evaluations are adequate for moving on to the next stage. As diagramed in the FFACO (1996, as amended March 2010), the corrective action strategy requires an external peer review before making this decision. A previous external peer review concluded that there was insufficient confidence in model predictions as a result of data limitations, ineffective model strategies, and uncertainty analyses that failed to address alternative geologic and hydrologic conceptual models (IT, 1999). The previous peer review panel recommended an integrated program of modeling and field data collection, and recommended exploring alternative conceptual models that might create localized vertical flows between the alluvium and the lower carbonate aquifer (LCA) down through "gaps in" and/or "faults through" the volcanic confining units and into the LCA.

Based on the results of the previous peer review panel, a decision was made at that time to continue in the CAI stage. Since 1999, extensive data collection and modeling evaluations have been conducted as part of the second phase of the CAI stage, including the following:

- Performing data collection, including drilling, hydrologic testing, and field and laboratory testing.

- Performing geophysical investigations, including a detailed 3-D seismic survey spanning the two test areas. 
- Modeling the groundwater environment and the radiological source term, and forecasting future extent of radiological contamination for 1,000 years.

- Conducting iterative model evaluations, and monitoring groundwater near and downgradient of test areas.

- Identifying and documenting land-use policies designed to restrict future public access to groundwater contaminated by underground testing.

Integrated interpretation of the existing geologic and geophysical information together with new deep boreholes significantly increased the inferred thickness of the alluvial fill in the basin and the thickness and spatial extent of the volcanic hydrostratigraphic unit. The new data, particularly the 3-D seismic and accompanying gravity data, greatly refined the subsurface faulting pattern in the Frenchman Flat basin. These data resulted in a number of changes in the base hydrostratigraphic model and enabled the development of a series of viable alternative hydrostratigraphic models.

In addition, based on the recommendations of the 1999 peer review panel (IT, 1999), the computational methods used for groundwater flow and transport modeling were revised, and the models of Frenchman Flat were updated. The groundwater flow models for the Frenchman Flat were redeveloped for the base and alternative hydrostratigraphic models, taking boundary conditions and recharge distributions from regional flow models. Calibration and Monte Carlo analysis addressed a range of flow rates through the test cavities and transport parameters, leading to estimated contaminant boundaries for each test site.

Sufficient confidence has now been developed in the site characterization and modeling to seek a second external peer review. This report documents that external peer review, which was conducted between April and September 2010. The peer review team was tasked with addressing the following questions:

1. Are the modeling approaches, assumptions, and model results for Frenchman Flat consistent with the use of modeling studies as a decision tool for resolution of environmental and regulatory requirements?

2. Do the modeling results adequately account for uncertainty in models offlow and transport in the Frenchman Flat hydrological setting?

a. Are the models of sufficient scale/resolution to adequately predict contaminant transport in the Frenchman Flat setting? 
b. Have all key processes been included in the model?

c. Are the methods used to forecast contaminant boundaries from the transport modeling studies reasonable and appropriate?

d. Are the assessments of uncertainty technically sound and consistent with state-of-the-art approaches currently used in the hydrological sciences?

3. Are the datasets and modeling results adequate for a transition to CAU monitoring studies - the next stage in the UGTA strategy for Frenchman Flat?

The external peer review team comprised the following members:

- Mary Lou Zoback, Risk Management Solutions, Newark, California

- Chunmiao Zheng, Department of Geological Sciences, University of Alabama

- Douglas Walker, Illinois State Water Survey, Champaign, Illinois

- James Rumbaugh, Environmental Simulations Inc., Reinholds, Pennsylvania

- Ken Czerwinski, Department of Chemistry, University of Nevada, Las Vegas

- Charles Andrews, S.S. Papadopulos \& Associates, Inc., Bethesda, Maryland

Appendix A presents brief resumes of the peer review team members.

The peer review process started with a four-day meeting in Las Vegas, Nevada, from April 6 to 9, 2010. This meeting (see Appendix B) consisted of technical presentations and a site visit conducted by project staff to review the site conditions, field experiments, data collection, and modeling activities of the CAI of Frenchman Flat. Following the initial meeting, periodic conference calls among the team members were held to discuss the tasks of the team, and a team meeting was held on June 7 and 8, 2010, at the University of Nevada, Las Vegas. The team prepared a draft report of its findings in June 2010 and presented its findings to project staff at a meeting in Las Vegas on August 19, 2010.

This report is organized into 10 sections, including this introduction section. Section 2.0 provides background information on Frenchman Flat, the radiological source terms, and the contaminant boundaries that have been calculated. Section 3.0 describes and provides comments on some of the basic data on geology and hydrogeology in Frenchman Flat reviewed by the peer review team to provide foundation for answering the questions for which it was tasked. Section 4.0 is a general discussion on the use of mathematical models as regulatory decision tools to frame the peer review team's opinions on the three review questions. Sections 5.0 through 7.0 discuss the peer review 
team's response to the three questions. Section 8.0 discusses the limitations of analyses that assume that geologic and groundwater conditions are static for the next 1,000 years and are at steady state. Section 9.0 summarizes recommendations of the peer review team, and Section 10.0 lists the documents reviewed by the peer review team and references cited in this report. 


\subsection{BACKGROUND}

The NNSS lies approximately 65 miles northwest of Las Vegas, Nevada, in the southwestern portion of the United States. Frenchman Flat is a closed-drainage intermontane basin in the southeastern portion of the NNSS, bounded on the north by Massachusetts Mountain and the Halfpint Range, on the east by Ranger Mountains and Buried Hills, on the south by the Spotted Range, and on the west by the Wahmonie Hills. The valley floor of the basin slopes gently from the surrounding highlands to a low-lying playa area. Ground surface elevations range from more than 1,460 $\mathrm{m}$ above mean sea level (amsl) in the surrounding mountains to about $938 \mathrm{~m}$ amsl at Frenchman Lake playa. A surficial geologic map of Frenchman Flat and vicinity is shown on Figure 2-1.

The Frenchman Flat basin is an east-tilted half graben bounded on the southeast by the Rock Valley fault zone. The principal basin-bounding faults are interpreted as a series of fan-shaped normal faults emerging northerly from the oblique-slip Rock Valley fault zone. Alluvial debris shed from the surrounding highlands during basin development bury the older Tertiary and Paleozoic rocks in much of the area. The alluvium is over 1,220 m (4,000 feet [ft]) thick beneath the central portion of Frenchman Flat, where it overlies the Tertiary volcanic rocks. Basalt flows 8.5 million years old occur within the alluvium in the northern part of the basin. Underlying the Tertiary volcanic rocks is a thick sequence of Paleozoic-aged carbonates that are more than 3,000 $\mathrm{m}(9,840 \mathrm{ft})$ thick. These Paleozoic-aged carbonates form the LCA, a regional-scale aquifer flowing towards the south-southwest.

The water table in the alluvial fill in the central portion of the Frenchman Flat basin is more than $220 \mathrm{~m}(720 \mathrm{ft})$ below land surface, and is higher than water levels in the LCA. Downward flow has been hypothesized to occur from the alluvial fill to the LCA along the eastern and southern perimeters of the basin along the Rock Valley fault zone and where the Tertiary-aged volcanic units are thinner. To the northwest of the Frenchman Flat basin is the CP basin, a smaller basin whose floor lies about $150 \mathrm{~m}$ higher than Frenchman Flat. The Cane Spring fault zone separates the two basins. The water table in the central portion of the CP basin is about $110 \mathrm{~m}(360 \mathrm{ft})$ higher than the water table in the 


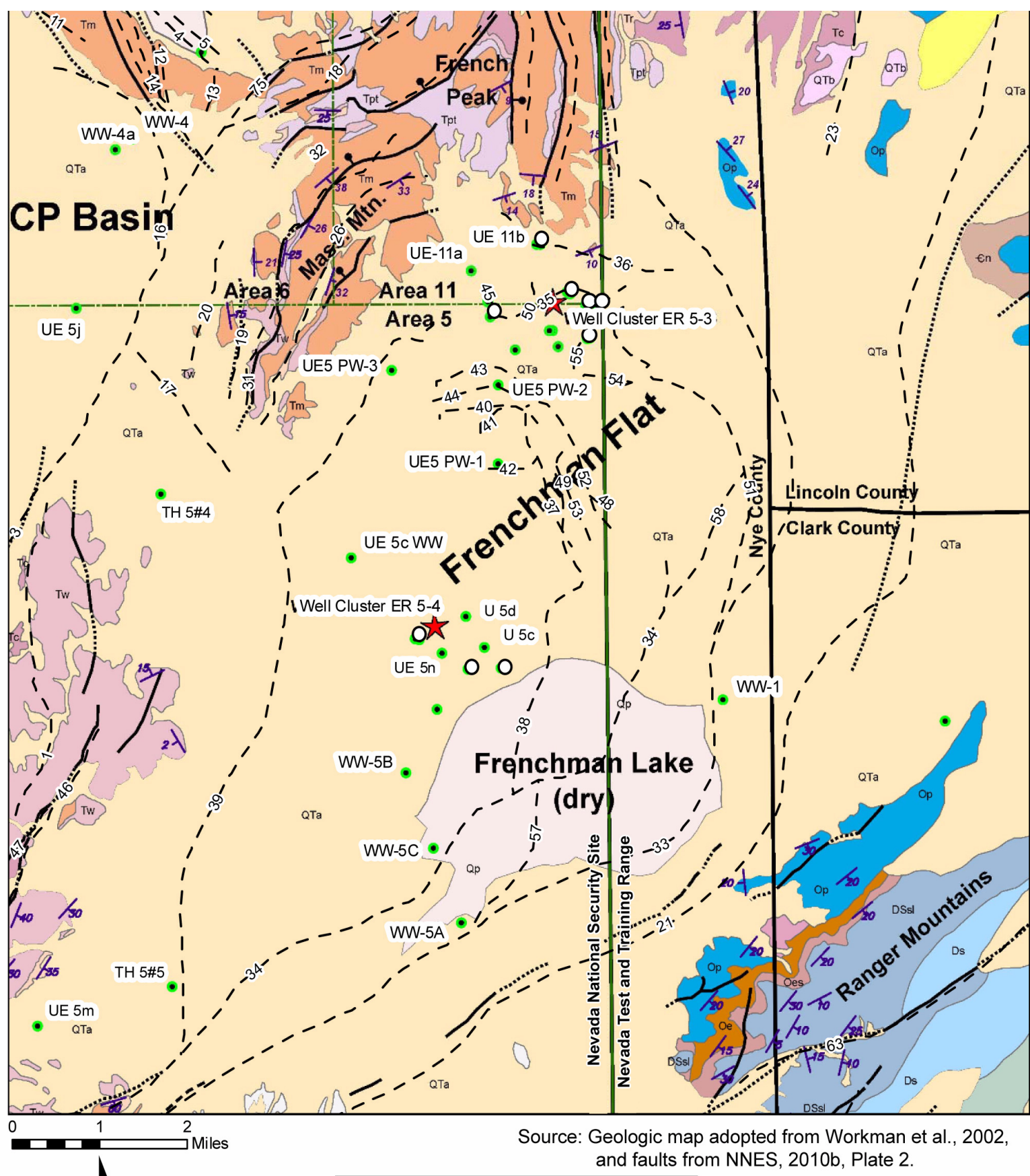

Explanation

- Monitoring Well or Borehole

- Nuclear Detonation

Figure 2-1

Surficial Geologic Map of Frenchman Flat and Vicinity 
alluvial fill in Frenchman Flat. Average annual precipitation on the floor of the Frenchman Flat basin is about 10 centimeters per year (cm/yr) (4 inches per year [in./yr]), but a negligible amount of this recharges the alluvial aquifer in Frenchman Flat, with recent studies indicating a net upward water flux near the surface on the basin floor (BN and Neptune, 2006). Some recharge may occur in higher elevation mountains surrounding Frenchman Flat, where average annual precipitation is about $25 \mathrm{~cm} / \mathrm{yr}(10 \mathrm{in.} / \mathrm{yr})$.

Nine of the 10 underground nuclear detonations in Frenchman Flat occurred above the water table, and one (CAMBRIC test) occurred about $74 \mathrm{~m}(243 \mathrm{ft})$ below the water table. At nine of the test locations, the water table is located in the alluvial fill. At the PIN STRIPE test location, the water table is located within the welded-tuff Topopah Spring aquifer. At the MILK SHAKE test location, where the water table is located in the alluvial fill, a basalt unit approximately $15 \mathrm{~m}(50 \mathrm{ft})$ thick occurs just a few meters below the water table.

Groundwater transport has been judged to be the primary pathway for subsurface contamination to migrate from the Frenchman Flat underground nuclear tests. Because the nuclear tests occurred above or near the water table, understanding groundwater flow at and near the water table is essential for making meaningful forecasts of radionuclide migration. This groundwater flow is primarily horizontal. Vertical groundwater flow in the alluvium at the test areas is very small based on data from nested monitoring wells at ER 5-3 in the Northern Testing Area and ER 5-4 in the Central Testing Area, indicating negligible vertical hydraulic gradients in the alluvium.

Because of the complexity of the geologic setting of Frenchman Flat, the peer review team found it useful to develop maps depicting the surface geology and the geology at the water table in Frenchman Flat with the test locations, monitoring wells, and mapped faults shown. These maps are included in this report as Figures 2-1 and 2-2, respectively.

\section{$2.1 \quad$ Radionuclides}

The nuclear weapons testing at Frenchman Flat resulted in the environmental distribution of radioactive activation products, fission products, actinide elements, and tritium $\left({ }^{3} \mathrm{H}\right)$. During subsurface testing, radionuclides are distributed based on their chemical behavior and the physical processes from the energy release of the weapon (Bowen et al., 2001). The isotopes of refractory 


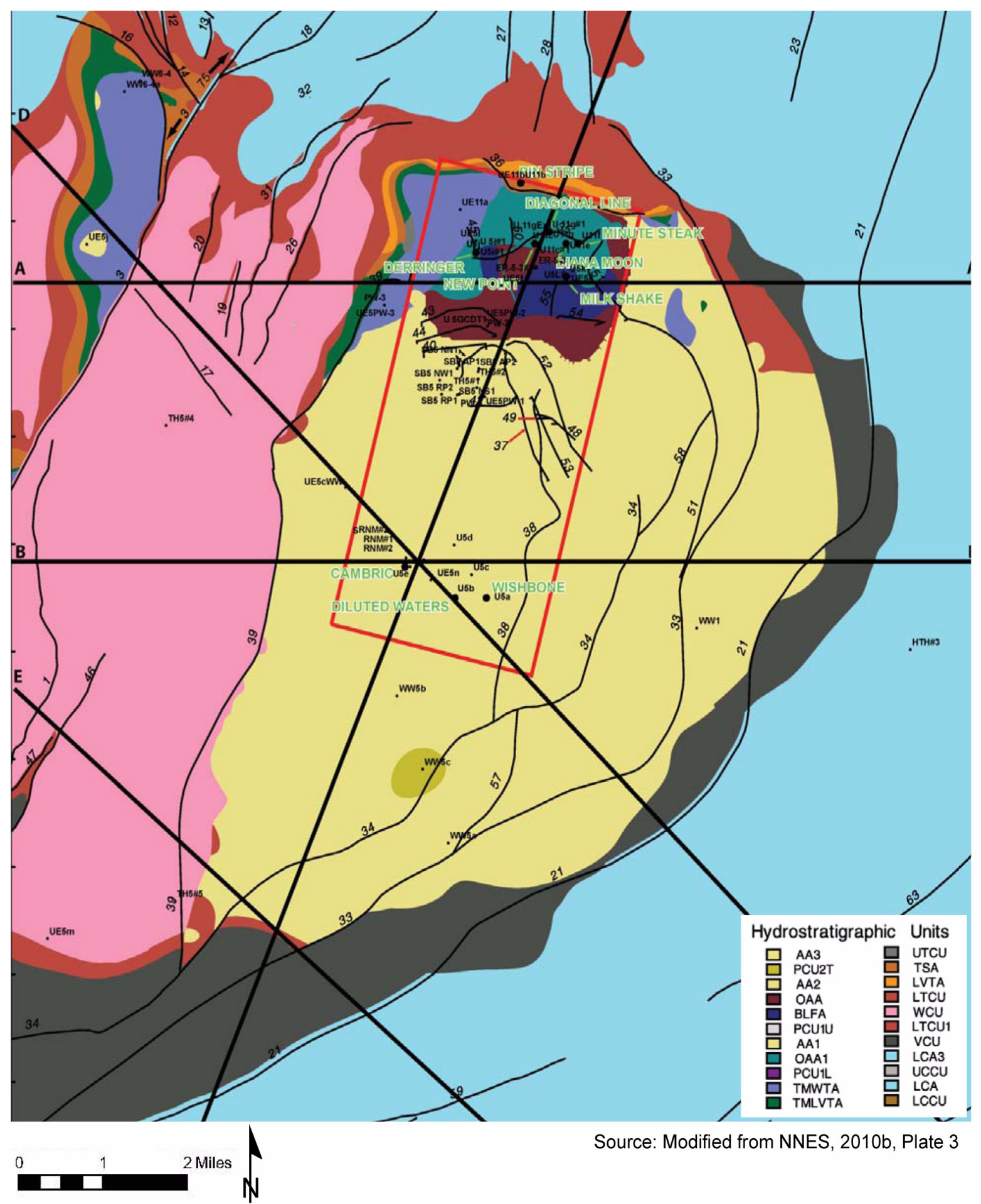

Figure 2-2

Geologic Map at Water Table, Frenchman Flat and Vicinity 
elements are concentrated in the bottom of the resulting cavity. These isotopes are largely entrained in the melt glass. Typical refractory elements include lanthanides, Group 2 elements (i.e., strontium, barium), zirconium, neptunium, and plutonium. Elements with higher volatility migrated up the chimney resulting from the nuclear test, with a distribution based on the chemical behavior of the radionuclides. Volatile species include the noble gases (xenon, krypton), ruthenium, chloride, and iodine. The decay of short-lived volatile isotopes can yield wider than expected distribution of the daughters (e.g., xenon-137 [ $\left.{ }^{137} \mathrm{Xe}\right]$ decaying with a 3.8 minute half-life to cesium-137 [ $\left.{ }^{137} \mathrm{Cs}\right]$ is a prime example of this behavior). Prompt injection may also provide a mechanism for enhanced migration of refractory elements.

Isotopes for inclusion in the source term can be divided into functional groups broadly based on formation and chemical behavior. Tritium is a singular case and can be separated into its own group. Neutron activation of geomedia formed isotopes outside of the fission product range. These include the isotopes carbon-14 $\left({ }^{14} \mathrm{C}\right)$, chlorine-36 $\left({ }^{36} \mathrm{Cl}\right)$, and calcium-41 $\left({ }^{41} \mathrm{Ca}\right)$. Typical fission products (i.e., ${ }^{137} \mathrm{Cs}$ and strontium-90 [ $\left.{ }^{90} \mathrm{Sr}\right]$ ) form another group. A fourth group consists of the actinides, primarily isotopes of uranium, plutonium, americium, and curium-244 $\left({ }^{244} \mathrm{Cm}\right)$ (Smith et al., 2003).

Bowen et al. (2001) estimated the inventory of radionuclides in the subsurface for each CAU at the NNSS. This inventory is reported radioactivity for 43 radionuclides associated with the nuclear tests as of September 23, 1992. Not all radionuclides that were produced from the testing were included in the inventory, as criteria were developed to exclude radionuclides with short half-lives and those produced in such low abundance that they never exceed regulatory criteria in groundwater. These criteria effectively excluded almost all radionuclides with half-lives less than 10 years. This inventory also does not include the contamination from 14 atmospheric tests conducted from 1951 to 1962 at Frenchman Flat. Such surface contamination is outside the scope of the present report. The uncertainties in the estimated inventory of radionuclides by group at each of the CAUs were estimated by Bowen et al. (2001) and are listed in Table 2-1.

The radionuclide inventory for each of the 10 tests conducted in Frenchman Flat was specified in the modeling analyses conducted to calculate the contaminant boundaries as equal to the total inventory estimated by Bowen et al. (2001) for the Frenchman Flat CAU divided by 10 to account for each subsurface nuclear test and decay corrected. This average method of calculating the inventory was 
Table 2-1

Radionuclide Inventory Uncertainty

\begin{tabular}{|c|c|}
\hline Radionuclide Group & Uncertainty \\
\hline \hline Fission products & $10-30 \%$ \\
\hline Unspent fuel & $20 \%$ or better \\
\hline Fuel activation products & $50 \%$ or better \\
\hline Residual $^{3} \mathrm{H}$ & $300 \%$ or better \\
\hline Activation products & Factor of 10 \\
\hline
\end{tabular}

used because the estimated inventory at each of the test location is classified. Because the specific radionuclide production and distribution are highly coupled with the device yield, the use of this averaging method to specify the inventory for the tests may induce significant uncertainty in the calculations of the contaminant boundaries. This uncertainty is not evaluated in the Phase II documents.

Evaluation of potential radionuclide migration based on all of the transport analyses conducted for Frenchman Flat indicated that five radionuclides control the calculated contaminant boundaries. These five radionuclides - ${ }^{3} \mathrm{H},{ }^{14} \mathrm{C},{ }^{36} \mathrm{Cl}$, technetium-99 $\left({ }^{99} \mathrm{Tc}\right)$, and iodine-129 $\left({ }^{129} \mathrm{I}\right)$ — all decay through beta decay and constitute 92 percent of the source-term inventory based on activity (Bowen et al., 2001). These radionuclides have chemical forms that are mobile in the environment.

Most ${ }^{3} \mathrm{H}$ is in the form of water and is therefore a conservative tracer. Anionic species, $\mathrm{Cl}^{-}, \mathrm{I}^{-}$, and pertechnetate $\left(\mathrm{TcO}_{4}^{-}\right)$, are also expected to be conservative tracers, but not to the same degree as ${ }^{3} \mathrm{H}$. Technetium, if reduced to the tetravalent oxidation state, would be immobilized as technetium oxide $\left(\mathrm{TcO}_{2}\right)$ or entrained with colloids. The other isotope of concern, ${ }^{14} \mathrm{C}$, would have chemical forms of carbonates and carbon dioxide. The selection of ${ }^{3} \mathrm{H},{ }^{14} \mathrm{C},{ }^{36} \mathrm{Cl},{ }^{99} \mathrm{Tc}$, and ${ }^{129} \mathrm{I}$ as isotopes of concern is logical based on the expected environmental chemistry. The noble gases argon and krypton also have high mobility but are not controlled by a maximum permissible limit in drinking water.

Radionuclides that sorb strongly to mineral and organic phases can potentially be transported in groundwater as colloidal phases. The influence of colloids on the transport of plutonium $\left({ }^{238} \mathrm{Pu},{ }^{239} \mathrm{Pu}\right.$, $\left.{ }^{240} \mathrm{Pu},{ }^{241} \mathrm{Pu},{ }^{242} \mathrm{Pu}\right)$ and americium $\left({ }^{241} \mathrm{Am},{ }^{243} \mathrm{Am}\right)$ was considered in detailed analyses conducted for the PIN STRIPE test, where groundwater migration is in fractured volcanic rocks; and for the DIANA 
MOON test, where groundwater migration occurs in zeolitized older alluvium (NNES, 2010b, Appendix C). It was concluded that colloid-facilitated transport enhances the migration of plutonium and americium in the fractured rock from the PIN STRIPE test and, by extension, from the MILK SHAKE test. The calculated concentrations of plutonium and americium, though, are far below regulatory limits, and the contaminant boundaries (Table 2-2) are defined by the concentrations of the five radionuclides described above. Based on the evaluations of colloid-facilitated transport from the DIANA MOON test, it was concluded that colloid-facilitated transport was negligible in the older alluvium. The influence of colloidal transport on other radionuclides, particularly lanthanides, was not considered. From the list of radionuclides resulting from testing (Smith et al., 2003), a number can interact with colloids. The transport of these radionuclides is expected to be limited based on their release from the glass source. However, as they were not considered for colloidal transport, it is unclear whether the exclusion of this transport route is reasonable.

Table 2-2

Calculated Contaminant Boundary Dimensions

\begin{tabular}{|c|c|c|c|c|}
\hline \multicolumn{2}{|c|}{ Test Name } & \multirow{2}{*}{$\begin{array}{c}\begin{array}{c}\text { Maximum } \\
\text { Contaminant } \\
\text { Boundary Length } \\
(\mathrm{m})\end{array} \\
500\end{array}$} & \multirow{2}{*}{$\begin{array}{c}\text { Maximum } \\
\text { Contaminant } \\
\text { Boundary Width } \\
(\mathrm{m})\end{array}$} & \multirow{2}{*}{$\begin{array}{c}\text { Maximum } \\
\text { Contaminant } \\
\text { Boundary Depth } \\
\text { below Water } \\
\text { Table } \\
(\mathrm{m})\end{array}$} \\
\hline \multirow{7}{*}{$\begin{array}{l}\text { Northern } \\
\text { Testing Area }\end{array}$} & DERRINGER & & & \\
\hline & DIAGONAL LINE & 220 & 200 & 35 \\
\hline & DIANA MOON & 150 & 190 & 30 \\
\hline & MILK SHAKE & 1,650 & 625 & 60 \\
\hline & MINUTE STEAK & 140 & 190 & 35 \\
\hline & PIN STRIPE & 1,610 & 350 & 15 \\
\hline & NEW POINT & 180 & 175 & 20 \\
\hline \multirow{3}{*}{$\begin{array}{c}\text { Central Testing } \\
\text { Area }\end{array}$} & CAMBRIC & 25 & 25 & 30 \\
\hline & DILUTED WATERS & 160 & 120 & 45 \\
\hline & WISHBONE & 180 & 130 & 30 \\
\hline
\end{tabular}

Source: NNES, 2010b, Section 10.0 


\subsection{Contaminant Boundaries}

The calculated contaminant boundary at each test site in the Northern and Central Testing Areas are shown on Figures 2-3 and 2-41, respectively, and the dimensions of the contaminant boundaries are listed on Table 2-2. The contaminant boundary is formally defined as the model-forecast perimeter that delineates the extent of radionuclide-contaminated groundwater from an underground test location over 1,000 years (also referred to as 1,000 year time-cumulative boundary). The boundary is defined to include the volume in which the calculated groundwater radionuclide concentrations exceeded the standards of the Safe Drinking Water Act (CFR, 2009) with a 95 percent degree of confidence at any time within 1,000 years. This volume is projected upward to the ground surface to define the contaminant boundary perimeter. The contaminant boundaries were delineated on the basis of many model realizations; the model realizations used to delineate the boundaries are listed on Table 2-3. The figures also show the calculated boundaries of the surface projection of the volume of groundwater contaminated at 50 years, 100 years, and 1,000 years after the testing with a 95 percent degree of confidence.

An interesting feature of the calculated contaminant boundaries is that the areal extent of the 3-D volume of contaminated groundwater does not significantly expand from 50 years after testing to 1,000 years after testing. Expansion is minimal after 50 years because of the relatively short half-life (12.32 years) of ${ }^{3} \mathrm{H}$, the dominant mobile radionuclide initially at the source locations. At later times, ${ }^{12} \mathrm{C}$ and ${ }^{36} \mathrm{Cl}$ are the main radionuclides that result in exceedances of standards. These radionuclides have half-lives of 5,730 and 301,000 years, respectively.

The maximum length of any of the contaminant boundaries is 1,650 $\mathrm{m}$ at the MILK SHAKE test, where migration occurs within a thin layer of basalt that is represented in modeling analyses as a permeable fractured aquifer. At seven of the test locations, migration occurs only within the alluvium; the maximum length of the contaminant boundaries for these tests is $220 \mathrm{~m}$ at the DIAGONAL LINE test. The maximum depth of any of the contaminant boundaries below the water table is $60 \mathrm{~m}$ at the MILK SHAKE test. Overall, it is notable that the maximum lengths and widths of the contaminant boundaries are relatively small.

1. The calculated contaminant boundaries shown on Figures 2-3 and 2-4 and described on Table 2-2 were determined during the time that this report was in preparation to overestimate the actual contaminant boundaries due to a computational error in the computer program PlumeCalc, which was used to calculate the boundaries. This error does not appear to significantly affect the calculated dimension of the contaminant boundaries. 


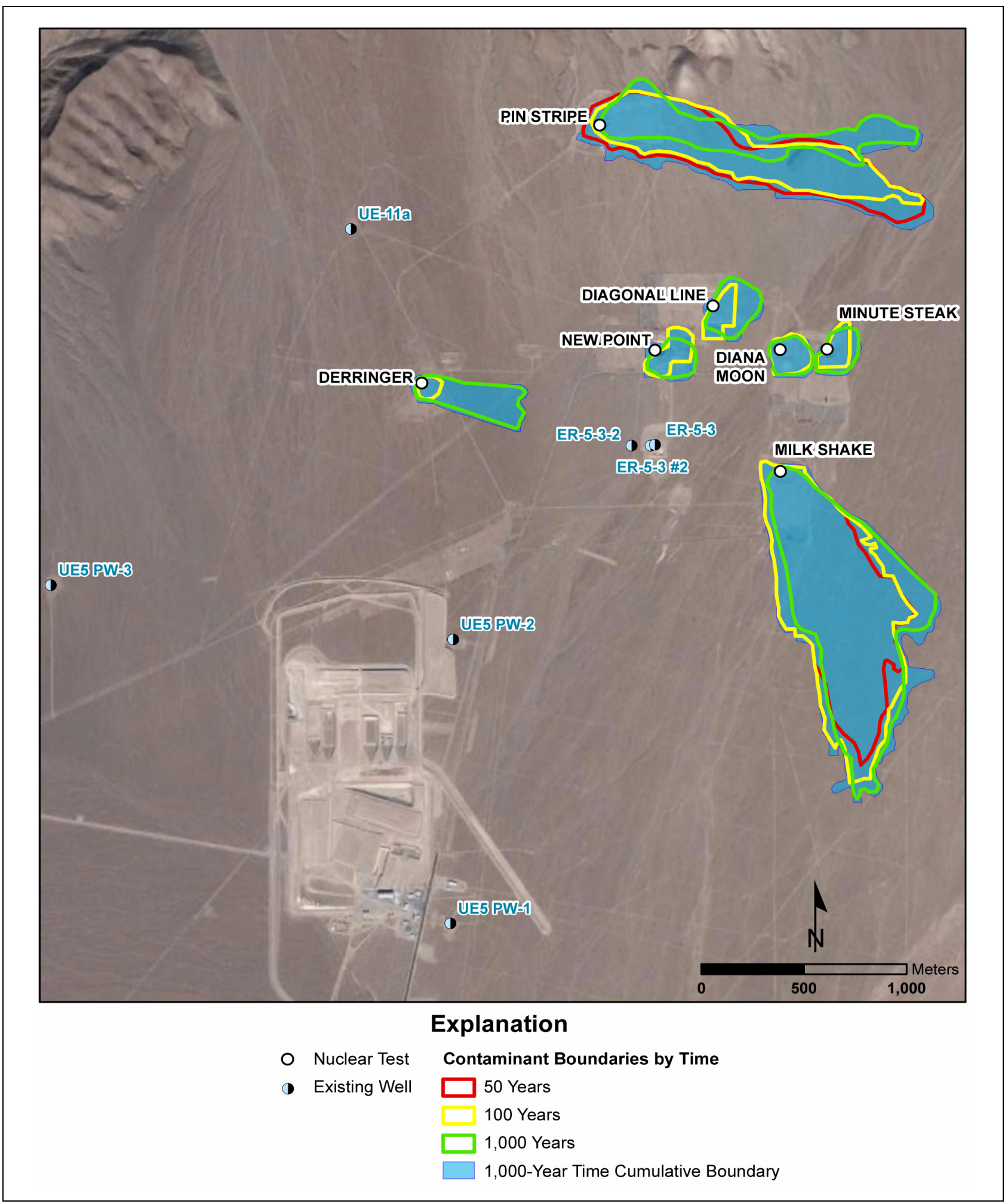

Figure 2-3

Calculated Contaminant Boundaries, Northern Testing Area 


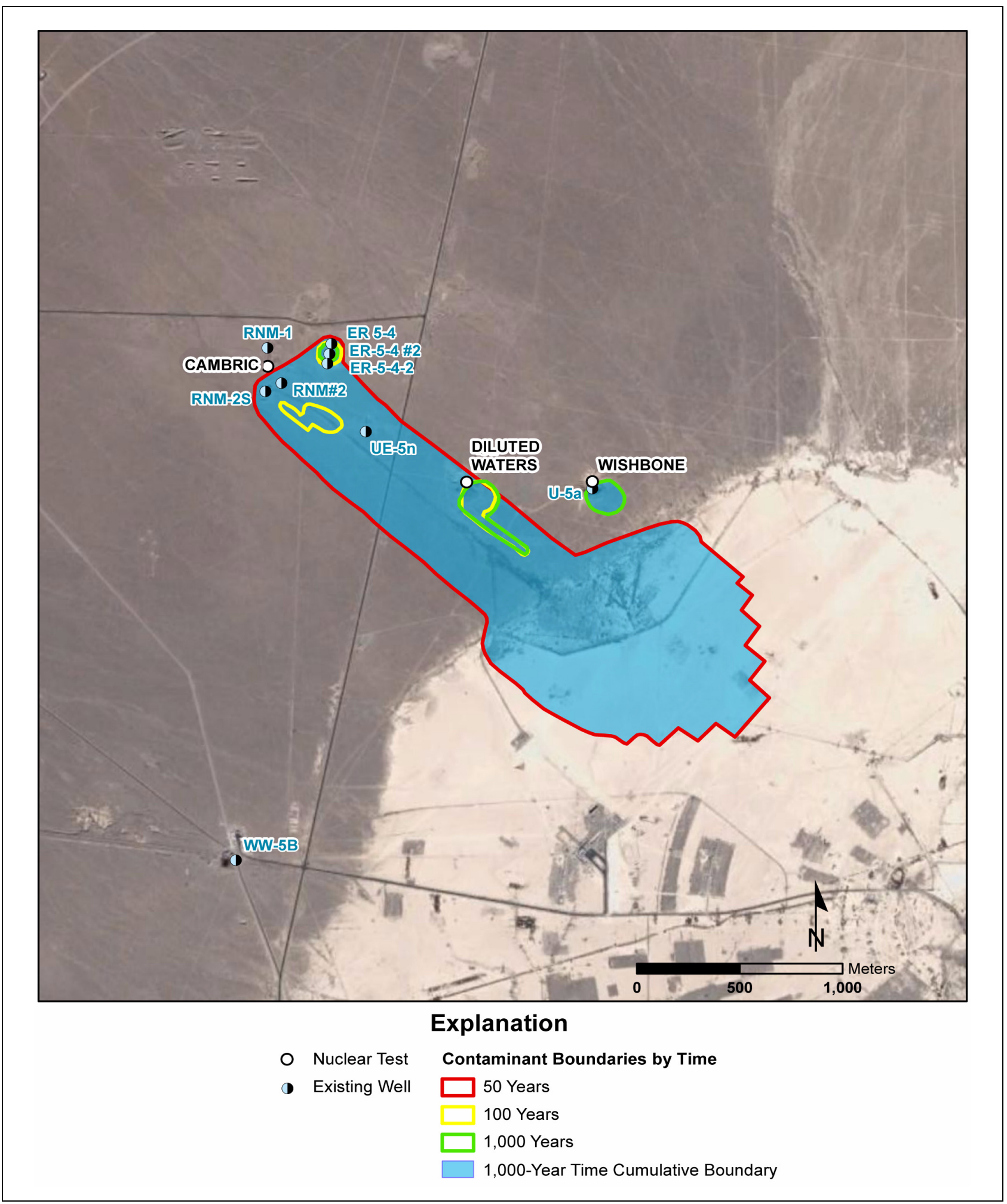

Figure 2-4

Calculated Contaminant Boundaries, Central Testing Area 
Table 2-3

Summary of Flow and Transport Realizations

\begin{tabular}{|c|c|c|c|c|}
\hline & Model & $\begin{array}{c}\text { Flow } \\
\text { Realizations }\end{array}$ & $\begin{array}{c}\text { Transport } \\
\text { Realizations }\end{array}$ & Select Comments \\
\hline & NHA-USGSD & 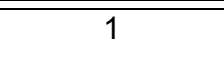 & 1,000 & \\
\hline & $\begin{array}{c}\text { Null-space Monte Carlo } \\
\text { NHA-USGSD }\end{array}$ & 100 & 1,000 & $\begin{array}{l}\text { For the PIN STRIPE and } \\
\text { MILK SHAKE simulations } \\
\text { only, both flow and } \\
\text { transport parameter } \\
\text { uncertainty was sampled } \\
\text { using simplified } \\
\text { process models. }\end{array}$ \\
\hline & $\begin{array}{c}\text { NHA-USGSD with extended } \\
\text { BLFA }\end{array}$ & 1 & 1,000 & $\begin{array}{l}\text { Evaluates the effect of the } \\
\text { larger BLFA HFM. }\end{array}$ \\
\hline & BASE-USGSD alternative & 1 & 1,000 & \\
\hline $\begin{array}{l}\text { Northern } \\
\text { Testing Area }\end{array}$ & $\begin{array}{l}\text { Null-space Monte Carlo } \\
\text { BASE-USGSD with } \\
\text { alternative BC }\end{array}$ & 100 & 100 & $\begin{array}{l}\text { For the PIN STRIPE and } \\
\text { MILK SHAKE simulations } \\
\text { only, both flow and } \\
\text { transport parameter } \\
\text { uncertainty was sampled } \\
\text { using simplified } \\
\text { process models. }\end{array}$ \\
\hline & $\begin{array}{l}\text { BASE-USGSD alternative } \\
\text { with extended BLFA }\end{array}$ & 1 & 1,000 & $\begin{array}{l}\text { Evaluates the effect of the } \\
\text { larger BLFA HFM. }\end{array}$ \\
\hline & $\begin{array}{l}\text { BASE-USGSD alternative } \\
\text { low dispersivity }\end{array}$ & 1 & 1,000 & \\
\hline & $\begin{array}{l}\text { BASE-USGSD alternative } \\
\text { high dispersivity }\end{array}$ & 1 & 1,000 & \\
\hline & DISP-USGSD & 100 & 100 & \\
\hline $\begin{array}{c}\text { Central } \\
\text { Testing Area }\end{array}$ & $\begin{array}{l}\text { BASE-USGSD with no } \\
\text { Depth Decay AA/OAA }\end{array}$ & 100 & 100 & \\
\hline & BASE-USGSD alternative & 100 & 100 & \\
\hline
\end{tabular}

Source: NNES, 2010b

$\mathrm{AA}=$ Alluvial aquifer

$B C=$ Boundary condition

BLFA = Basalt lava-flow aquifer alternative HFM

CPBA $=\mathrm{CP}$ thrust fault alternative HFM

DISP = Displacement fault (aquifer juxtaposition) alternative HFM

HFM $=$ Hydrostratigraphic framework model

$\mathrm{NHA}=$ Northern Hydrologic Alternative

OAA = Older alluvial aquifer

USGSD = U.S. Geological Survey Distributed Recharge Map 


\subsection{Observational Data}

The peer review team reviewed in detail water-level data, water-quality data, hydraulic properties data, and geologic data from Frenchman Flat to develop a basic understanding of the hydrogeologic system in the Frenchman Flat basin. This basic understanding was essential for purposes of evaluating the groundwater models used for calculating the contaminant boundaries and providing a foundation for answering the questions posed to the peer review team. This section describes observations of the peer review team in reviewing these data and describes a conceptual model of groundwater flow in the alluvial fill used by the peer review team.

\subsection{Water-Level Data}

Groundwater monitoring wells are sparse in Frenchman Flat. The available water-level data are described in Stoller-Navarro Joint Venture (SNJV) (2004c, Section 8.0; and 2006, Appendix A). In the Northern Testing Area, only five monitoring wells are completed at or near the water table that have several water-level measurements during the period 1990 through 2010. Three of these wells-Pilot Wells UE-5 PW-1, UE-5 PW-2, and UE-5 PW-3 - were constructed specifically to determine the hydraulic gradient and direction of groundwater flow in the vicinity of the Area 5 Radioactive Waste Management Site (RWMS). Figure 3-1 shows the best estimates of the water levels at these monitoring wells, as described in SNJV (2006). Figure 3-1 also shows the locations of the seven underground nuclear tests in this area and the screened intervals of the five monitoring wells with water-level data. The water levels, which represent the approximate location of the water table, span the range of $773.74 \mathrm{~m}$ amsl to $773.90 \mathrm{~m}$ amsl, a total range of $0.16 \mathrm{~m}$ within an area of about 9 square kilometers ${ }^{1}$. Based on these data, there is significant uncertainty in the magnitude and direction of the hydraulic gradient, and some probability exists that groundwater flow could be in any direction.

1. Of the five wells, three (UE-5 PW-1, UE-5 PW-2, and ER-5-3 shallow) are screened in alluvial fill; Wells UE-11a and UE-5 PW-3 are screened in the volcanic rocks of the Timber Mountain welded-tuff aquifer. 


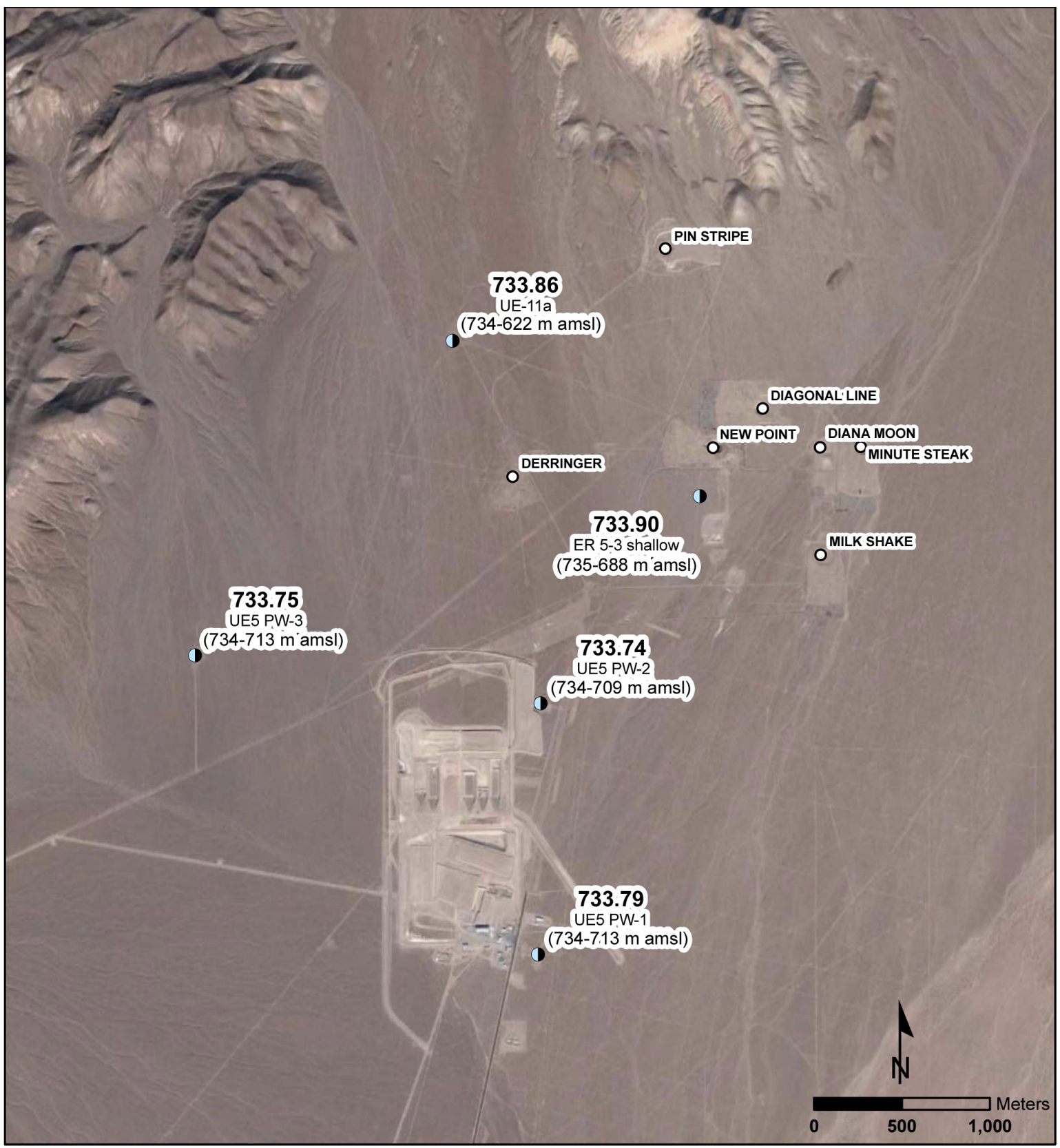

Source: SNJV, 2006, Appendix A. Posted water levels represent steady-state water levels as defined in this report.

\section{Explanation}

733.79 Water Level, $\mathrm{m}$ amsl

734-713 Screened Interval of Wells, $m$ amsl

Figure 3-1

Water Levels in Water-Table Wells, Northern Testing Area 
The direction and magnitude of groundwater flow between Wells UE-5 PW-2 and UE-5 PW-1 calculated with the groundwater models used to calculate the contaminant boundaries in the Northern Testing Area are shown on Figure 3-2 (based on Navarro Nevada Environmental Services, LLC [NNES], 2010a, Figure 7-18). The calculated flow directions are predominately towards the southeast with flow directions ranging from east to south. Unlike the observed data, the calculated directions of groundwater flow have a strong preferred orientation. The calculated rates of groundwater flow range from 3 meters per 1,000 years $(\mathrm{m} / 1,000 \mathrm{yr})\left(1 \times 10^{-10}\right.$ meters per second $\left.[\mathrm{m} / \mathrm{s}]\right)$ to $3,150 \mathrm{~m} / 1,000 \mathrm{yr}\left(1 \times 10^{-7} \mathrm{~m} / \mathrm{s}\right)$.

The peer review team was able to review additional water-level data for all three pilot wells collected quarterly between 2004 and March 2010 that were not available at the time the groundwater models were calibrated. Figure 3-3 shows a plot of available water-level data for these wells (UE-5 PW-1, UE-5 PW-2, and UE-5 PW-3) from 1990 through April 2010. There is significant scatter in the water-level data from these wells through about 1999, but since that time, there has been a relatively consistent downward trend in water levels at each of these wells, as shown on Figure 3-32. Water levels in the three wells have been declining at a rate of between 0.7 and 1.8 meters per 100 years $(\mathrm{m} / 100 \mathrm{yr})$.

The direction and magnitude of groundwater flow calculated with the water-level data from these wells through time are shown on Figure 3-4. During the past 10 years, the average direction of groundwater flow has been approximately to the south-southwest (about 190 degrees from north, or about 10 degrees west of south) with calculated directions from individual water-level measurements ranging from about 150 degrees from north to 210 degrees from north. The average direction of observed groundwater flow is outside the range of all of the directions calculated with the groundwater models, but the range of directions overlaps with the directions calculated with the groundwater flow models. The calculated magnitude of groundwater flow ${ }^{3}$ has been variable over the past 10 years but has averaged about $70 \mathrm{~m} / 1,000 \mathrm{yr}$. This magnitude of groundwater velocity is within the range calculated with the groundwater flow models. In fact, the range in velocities shown

2. The scatter in the pre-1999 water-level data may be the result of imprecise measurement methods; measurement methods are reported to have been consistent since about 1999 to the present.

3. This groundwater velocity was calculated based upon a hydraulic conductivity of the alluvial deposits at the water table of 1 meters per day $(\mathrm{m} / \mathrm{d}$ ) and a porosity of 0.38 (based on data on aquifer properties contained in spreadsheet PilotWell_Water_Levels20100426.xls). There is significant uncertainty associated with this estimate of the hydraulic conductivity. 


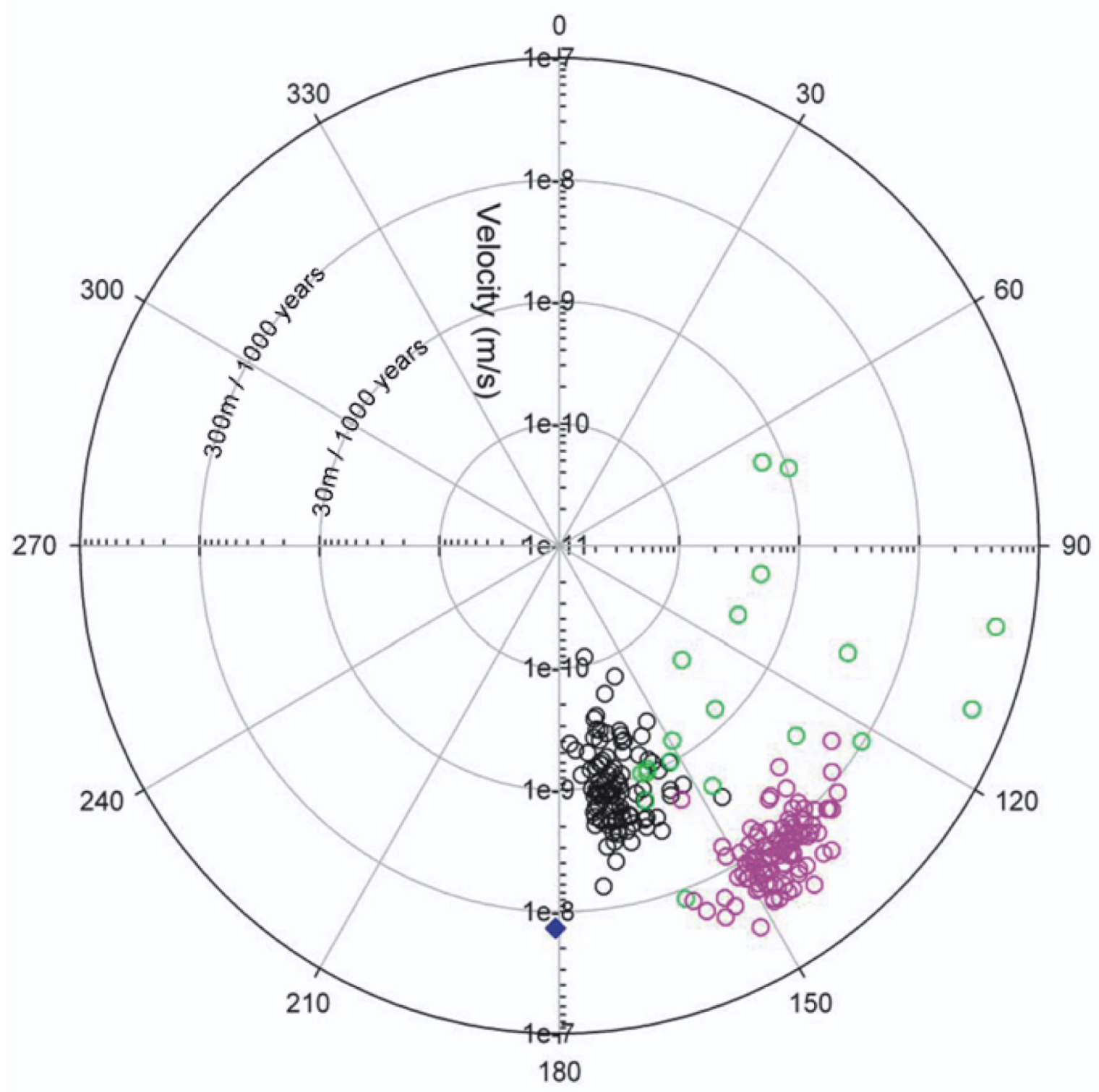

- NHA NSMC Calibrated Models

- Geochemistry Data

- Discrete Calibrated Models

- BASE-USGSD with Alternative Boundary Conditions NSMC Calibrated Models

Source: NNES, 2010b, Figure 7-18

Figure 3-2

Model Calculated Rates and Direction of Groundwater Flow, UE-5 PW-2 to UE-5 PW-1 
a) Water Levels in Pilot Wells 1990-2010

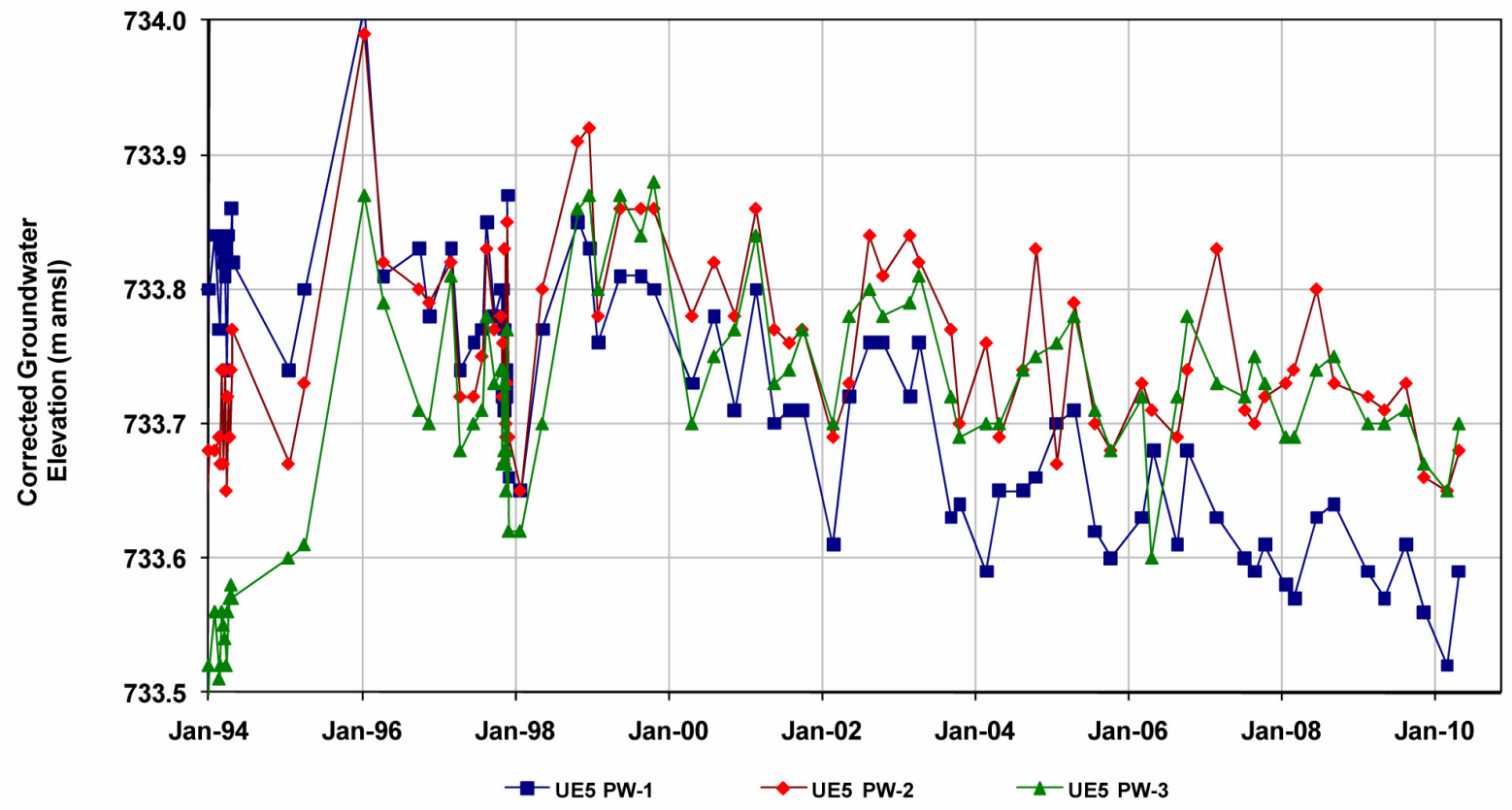

b) Water Levels in Pilot Wells 2000-2010 with Trends

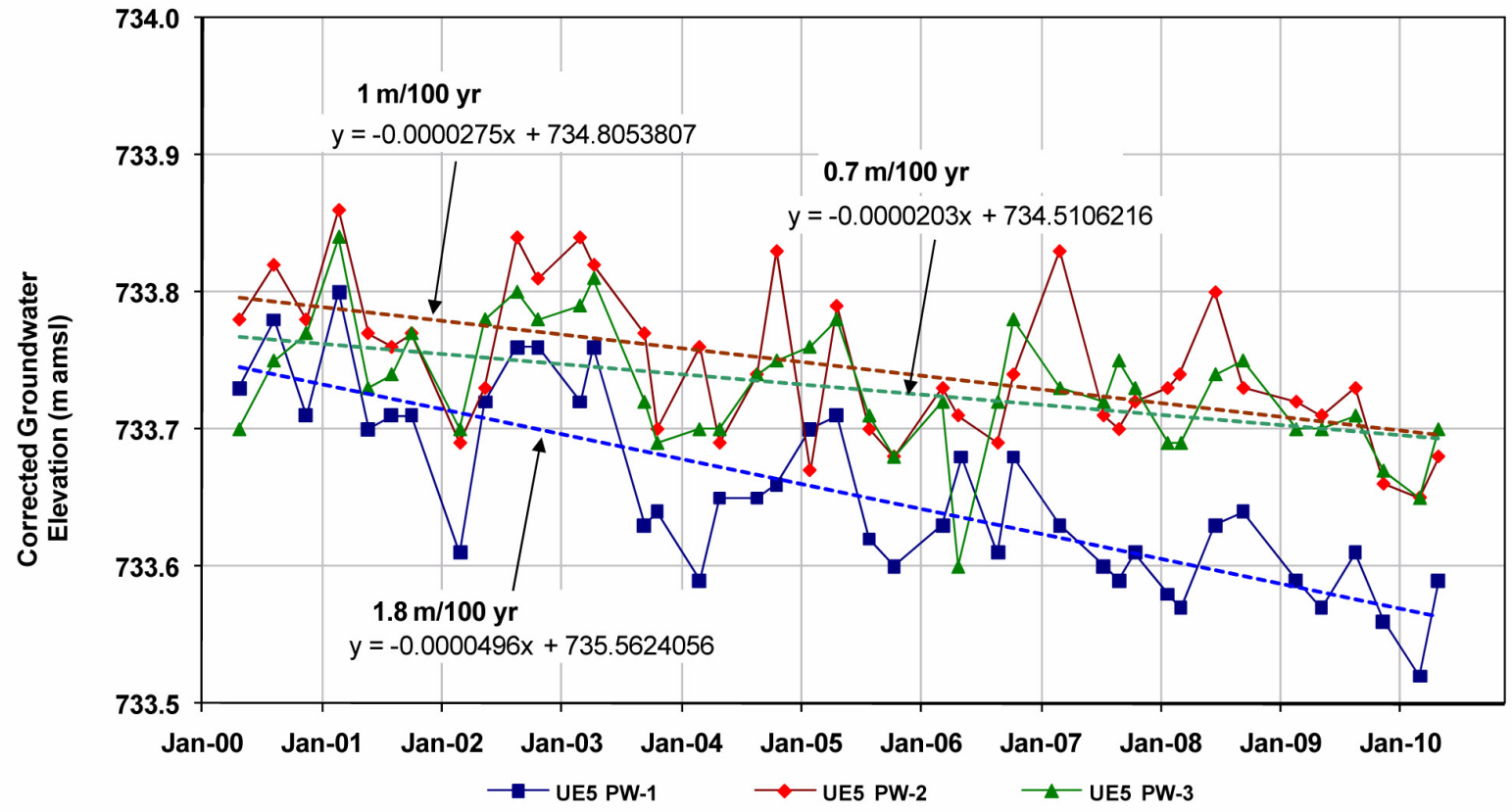

Figure 3-3

Water Levels in Pilot Wells 
a) Direction of Groundwater Flow at Pilot Wells 1993-2010

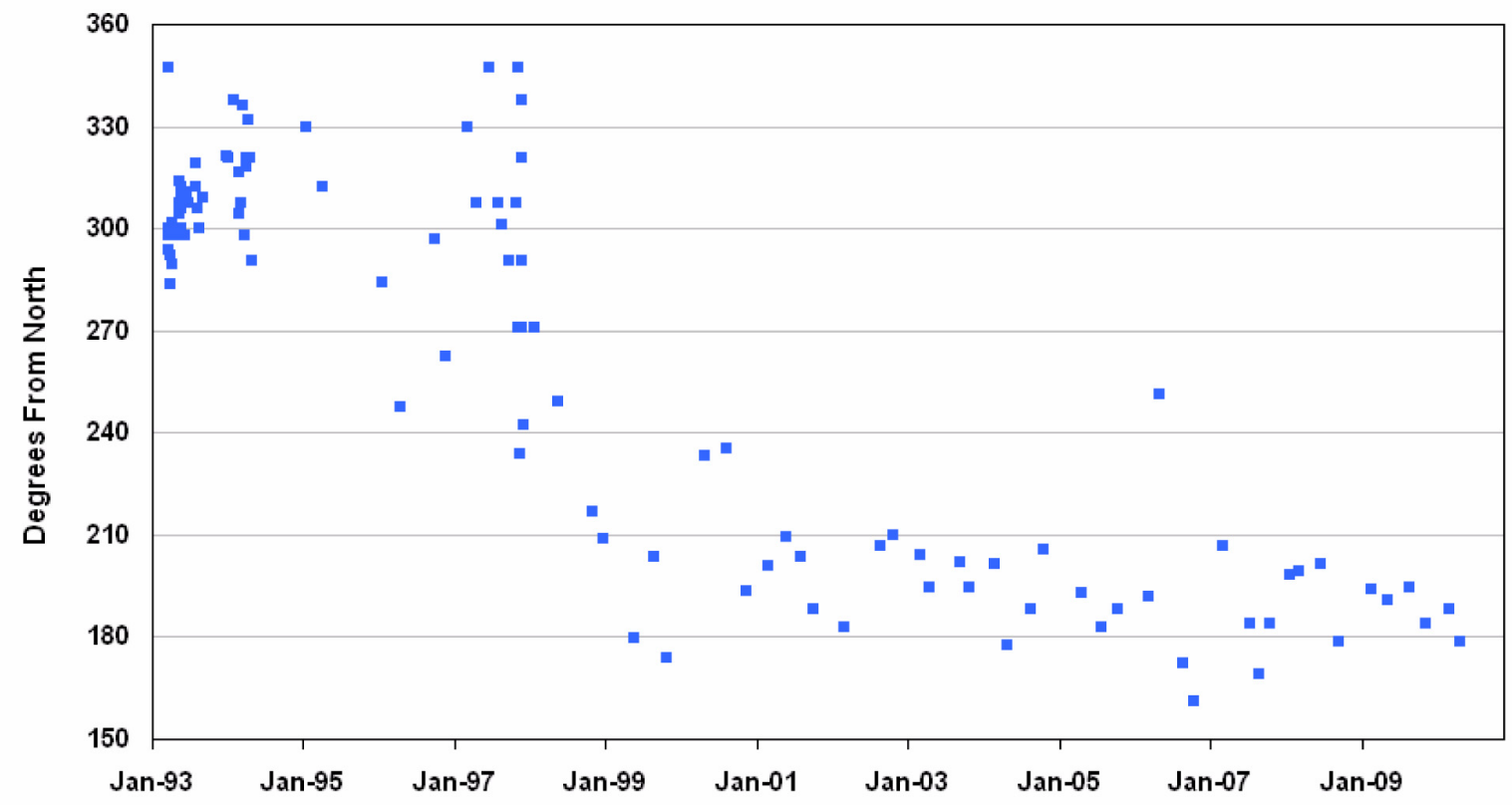

b) Rate of Groundwater Flow at Pilot Wells 1993-2010

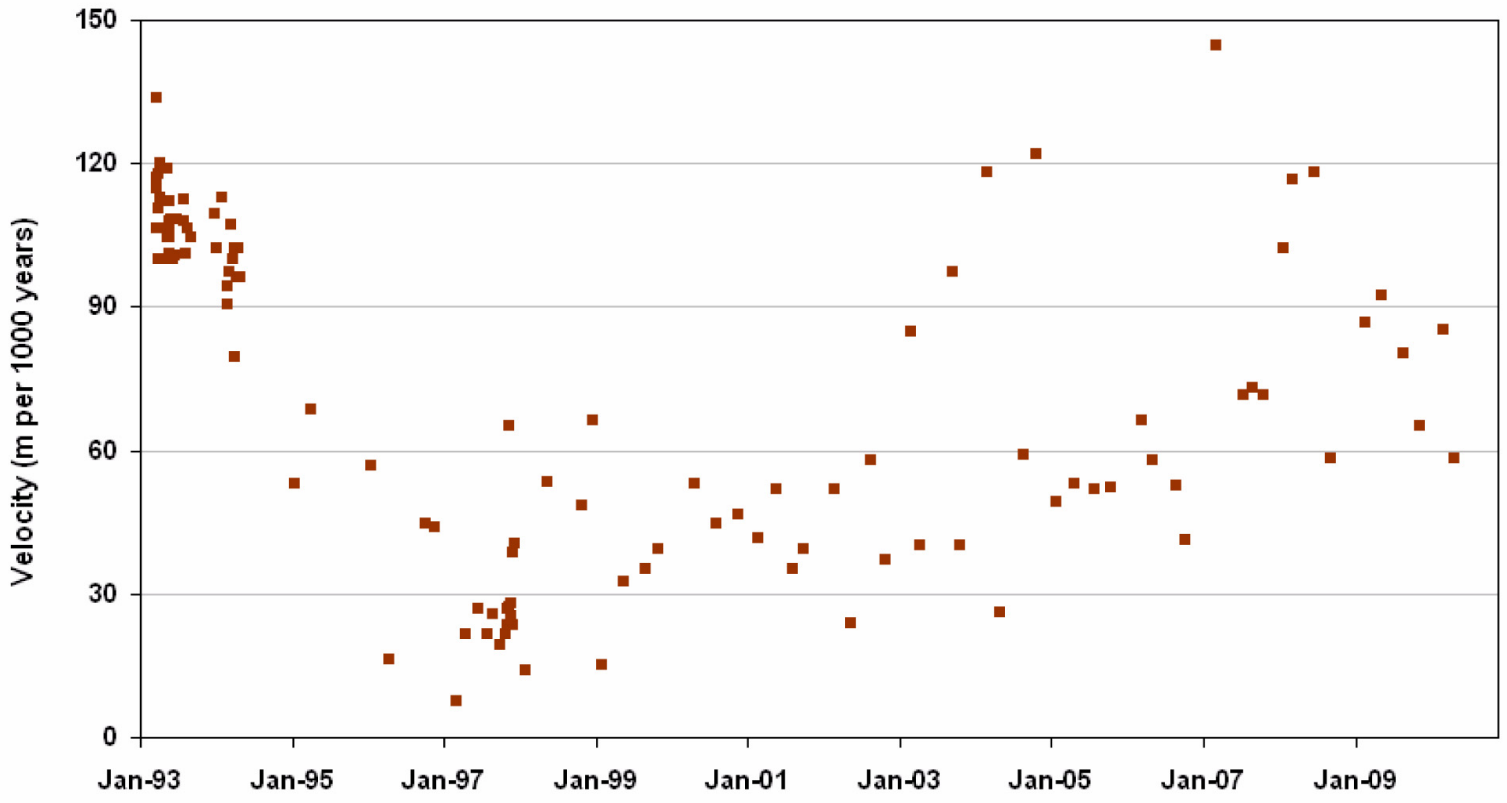

Figure 3-4

Direction and Rate of Flow at Pilot Wells 
in Figure 3-4 is similar to the range in velocities for the NHA null-space Monte Carlo calibrated models (see Figure 3-2).

The historical water levels in all monitoring wells screened at or near the water table in the vicinity of the Northern and Central Testing Areas are shown on Figure 3-54. All wells with data are shown on this figure, even the three wells for which only one water-level measurement is available. Of note on this figure is the fact that water levels in all monitoring wells located north and northwest of the playa have similar water levels and wells located south and east of the playa have significantly lower water levels. A dotted yellow line on Figure 3-5 is used to separate the two regions of distinct water levels.

A rather large water-level change occurs between Well WW-5B and WW-5C, an approximately 5.5-m (18-ft) change over a distance of about $1,435 \mathrm{~m}(4,700 \mathrm{ft})$. This is a very large change in water levels over a short distance, and none of the groundwater models that have been developed explain this large water-level drop or the relatively flat water-level surface in the northwestern half of Figure 3-55.

Figure 3-6 shows the measured water-level data from Wells WW-5B and WW-5C.

After reviewing the observed water-level data, the peer review team concluded the following:

- Observed water levels fall into two dichotomous classes: water levels northwest of the line shown on Figure 3-5 and water levels southeast of the line.

- None of the groundwater models that have been evaluated have accurately represented the large change in water levels that occurs about the line shown on Figure 3-3 between Wells WW-5B and WW-5C.

- Recent water-level data from the pilot wells suggest that the direction of groundwater flow in the vicinity of these wells is towards the south at a velocity on the order of $100 \mathrm{~m} / 1,000 \mathrm{yr}$, a very slow rate of movement.

- The assumption of steady-state water levels in all the groundwater models that have been developed may be incorrect. An evaluation of water-level data from the pilot wells suggests that water levels are falling on the order of $1 \mathrm{~m} / 100 \mathrm{yr}$. This decline may represent the slow movement of water from the alluvial system to the LCA following the last pluvial, which was more than 10,000 years ago.

4. Sources of data are SNJV (2004c, Section 8.0; and 2006, Appendix A).

5. The model calculated water-level difference between Wells WW-5B and WW-5C for the NHA model is $0.7 \mathrm{~m}$, for the BASE-USGSD with alternative boundary conditions is $1.2 \mathrm{~m}$, and for the DISP-USGSD is $2.6 \mathrm{~m}$. Source of data is the spreadsheet Frenchman_Flat_WLtargets_CalibWL.xls. 


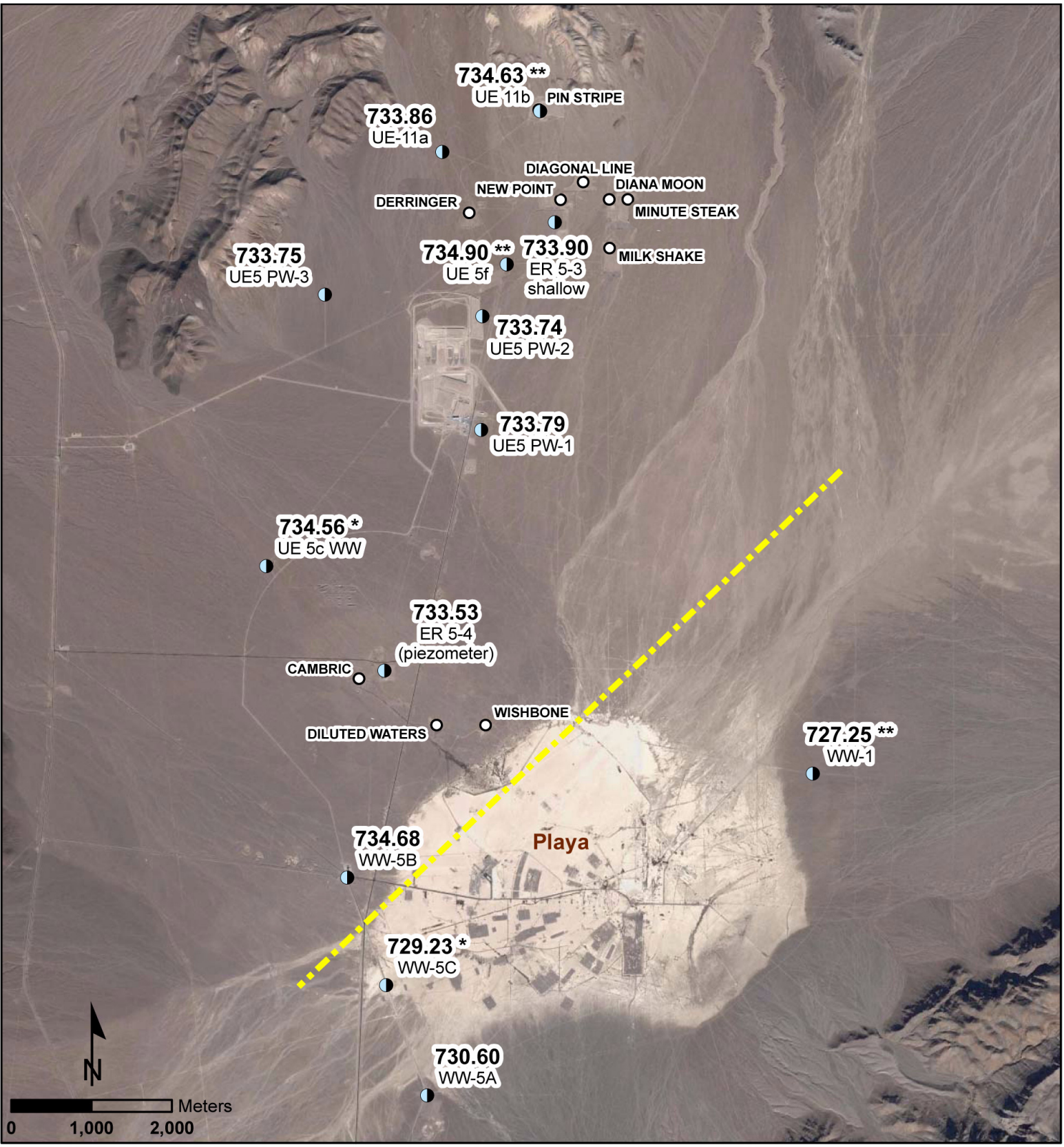

Notes: ${ }^{*}$ Indicates well is not screened at water table. ${ }^{* *}$ Indicates only one water-level measurement available.

Source: SNJV, 2004c, Section 8.0; and 2006, Appendix A

\begin{tabular}{|ll|}
\hline & Explanation \\
727.25 & Water Level (m amsl) \\
\hline
\end{tabular}

Figure 3-5

Water Levels in Water-Table Wells, Frenchman Flat 

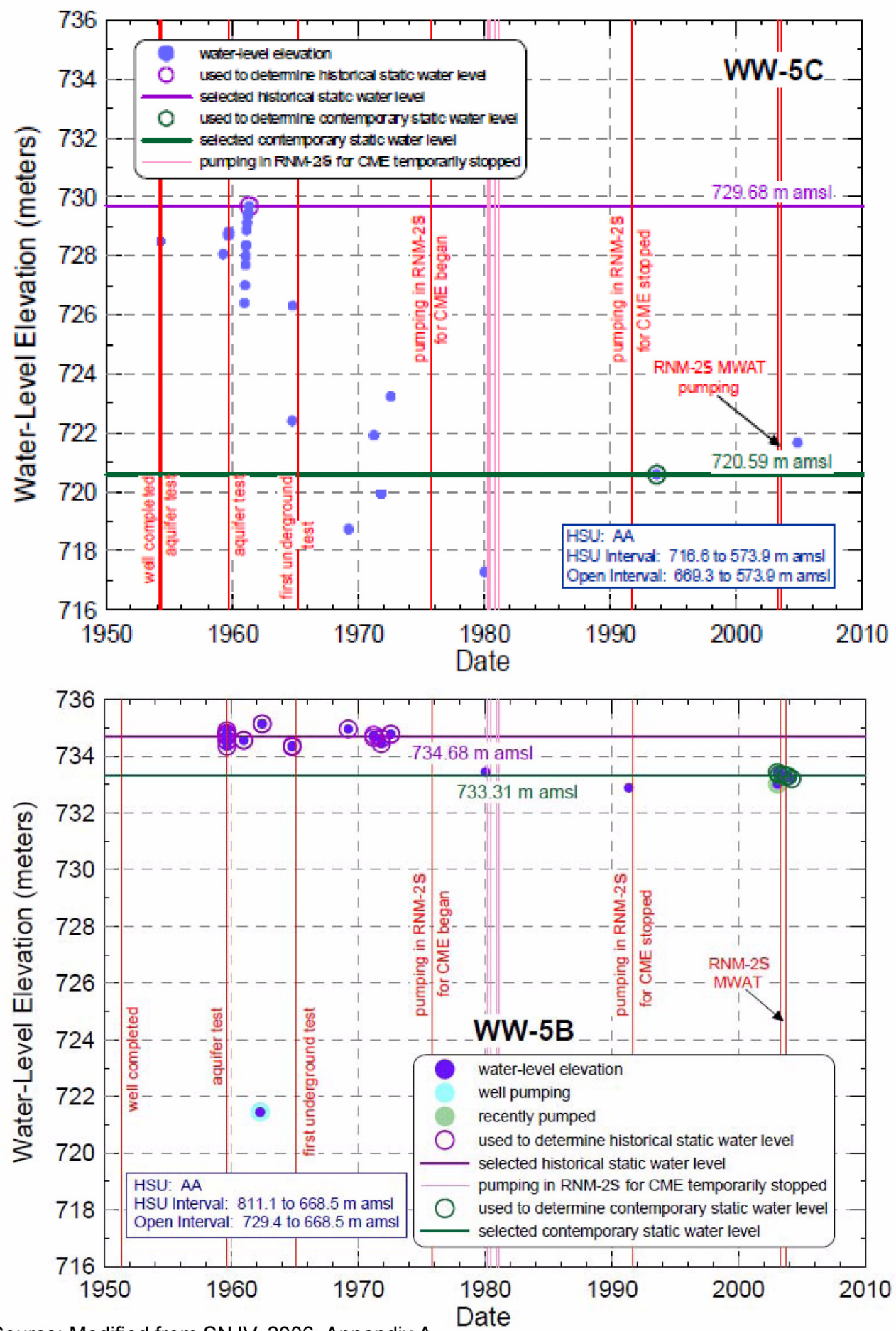

Source: Modified from SNJV, 2006, Appendix A

Figure 3-6

Measured Water Levels in Water Supply Wells WW-5B and WW-5C 


\subsection{Water-Quality Data}

Water-quality data were used as a source of information on the rate and direction of groundwater flow in the alluvium in the calibration of the NHA model. The peer review team reviewed available water-quality data for purposes of evaluating the reliability of water-quality data for estimating rates and direction of groundwater flow and determining whether the water-quality data provided additional information on the dichotomy in water levels within Frenchman Flat. Some observations of the peer review team on groundwater age and quality characteristics are discussed in the following sections.

\subsubsection{Groundwater Age}

A number of different approaches were used to date the groundwater in Frenchman Flat. These methods rely upon combinations of radioactive decay, stable isotope exchange, and cation exchange. Figure 3-7 shows the groundwater ages that were determined. The screen depth below the water table of the wells with ages is variable. Many of the wells are screened across the water table, but wells such as ER 5-3 (composite) and ER 5-4 (main) are screened hundreds of meters below the water table. It is very likely that groundwater age is not constant with depth in the alluvium, and thus some of the variability in groundwater ages shown on Figure 3-7 is the results of variable sampling depths (e.g., Engesgaard and Molson, 1998; Castro and Goblet, 2005).

The peer review team made a number of observations regarding the groundwater ages:

- The alluvial groundwater in Frenchman Flat and CP basin is older than 9,000 years.

- There is no obvious spatial pattern in groundwater ages, though the youngest groundwater is found near the Northern Testing Area and the oldest groundwater is found near the Central Testing Area.

- There is a very large difference in groundwater age between WW-5B and WW-5C, which are located at the dichotomy in water levels discussed above - approximately a 10,000-year difference. On the other hand, the estimated groundwater age at WW-1, which is located to the southeast of the line shown on Figure 3-5, is similar to the age of groundwater from wells located northwest of the line.

- The groundwater age at Well UE-11a is not consistent with recharge on the flanks of Massachusetts Mountain, as modeled in the NHA. 


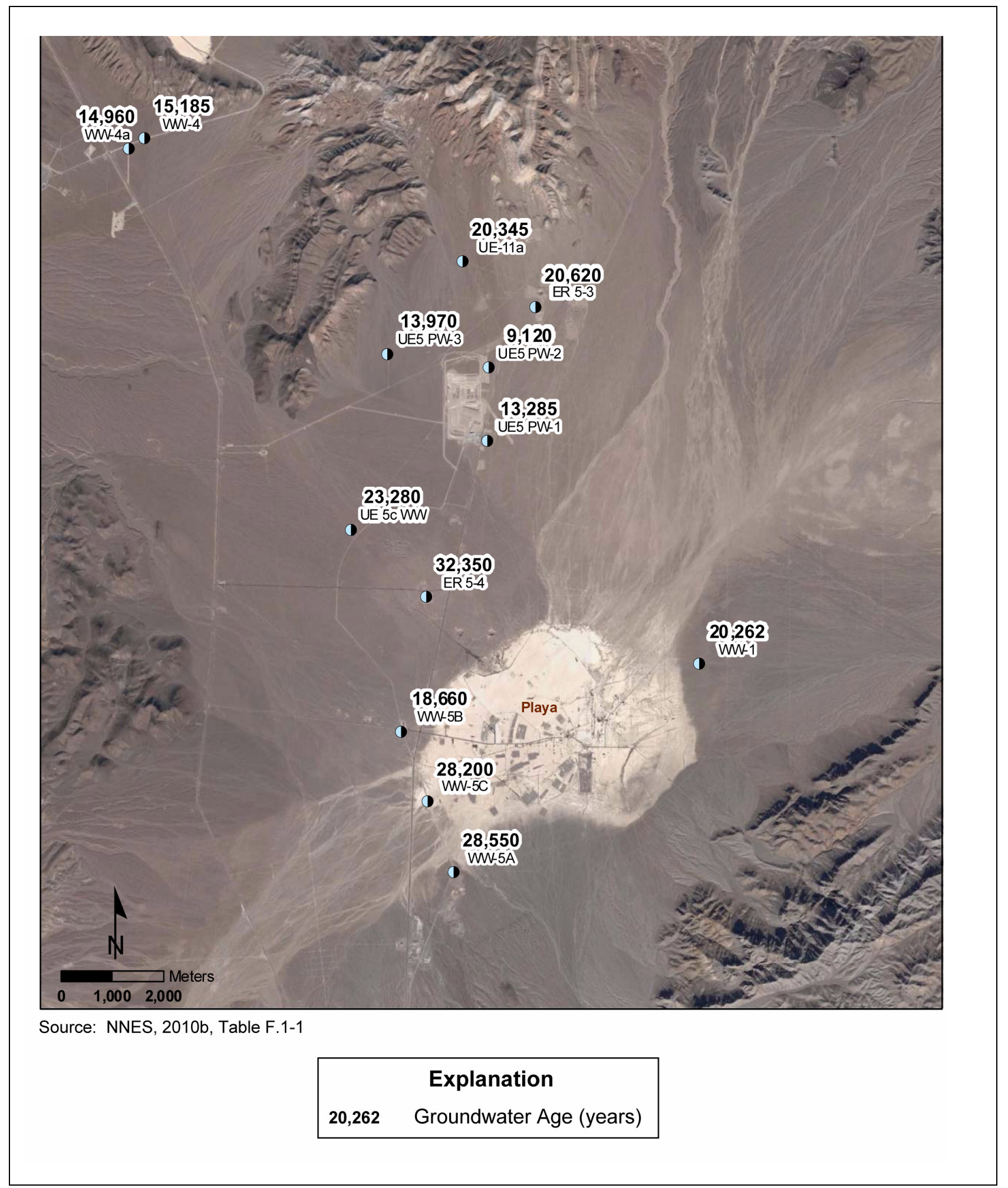

Figure 3-7

Groundwater Age, Frenchman Flat and CP Basin 
- The interpretation of geochemical ages did not consider the screened interval of the monitoring wells. The evaluations implicitly assume that the age of the groundwater is constant with depth below the water table. The peer review team is of the opinion that this is highly unlikely. For example, a well pair used to evaluate groundwater velocities was Well UE-5 PW-1 and Well ER 5-4 (main/composite). The former well is screened across the water table with a screen interval of 713 to $734 \mathrm{~m}$ amsl, whereas the latter well is screened over the interval -183 to $432 \mathrm{~m}$ amsl (interval 36 to $286 \mathrm{~m}$ amsl is not screened).

\subsubsection{Groundwater Quality Characteristics}

As groundwater moves away from recharge areas, it is expected that the ratio of sodium to calcium will increase. This occurs because of two main processes: (1) the removal of $\mathrm{Ca}^{2+}$ from the water by exchange with sodium containing clays and zeolites, and (2) the dissolution of sodium chloride in the alluvial sediments. Figure 3-8 shows the spatial distribution of sodium and calcium in groundwater. There is, however, a large change in the sodium to calcium ratio between Wells WW-5B and WW-5C, suggesting some type of dichotomy in the groundwater flow system in this area. In general, sodium concentrations and the ratio of sodium to calcium are lowest in the northwestern portion of Frenchman Flat and largest in the southeast. The higher sodium concentrations in the southeast may be related to the playa deposits.

The spatial pattern is difficult to interpret because the sampled wells are screened at various depths below the water table, and the ratio of sodium to calcium varies with depth. For example, in the Central Testing Area in the vicinity of Well ER 5-4, there is significant variability in sodium and calcium concentrations with depth as shown in Table 3-1.

Chloride concentrations in groundwater generally increase in the direction of groundwater flow as chloride is derived from mineral dissolution along a groundwater flow path. Chloride concentrations in groundwater in Frenchman Flat are posted on a map of Frenchman Flat (Figure 3-9) to illustrate the spatial distribution of chloride concentrations in groundwater. The data display no strong spatial pattern. The peer review team notes the following:

- The chloride concentrations in the three pilot wells near the Northern Testing Area are similar to chloride concentrations from the three wells (WW-1, WW-5A, WW-5C) that have significantly lower water levels located in the southeastern part of Frenchman Flat. 


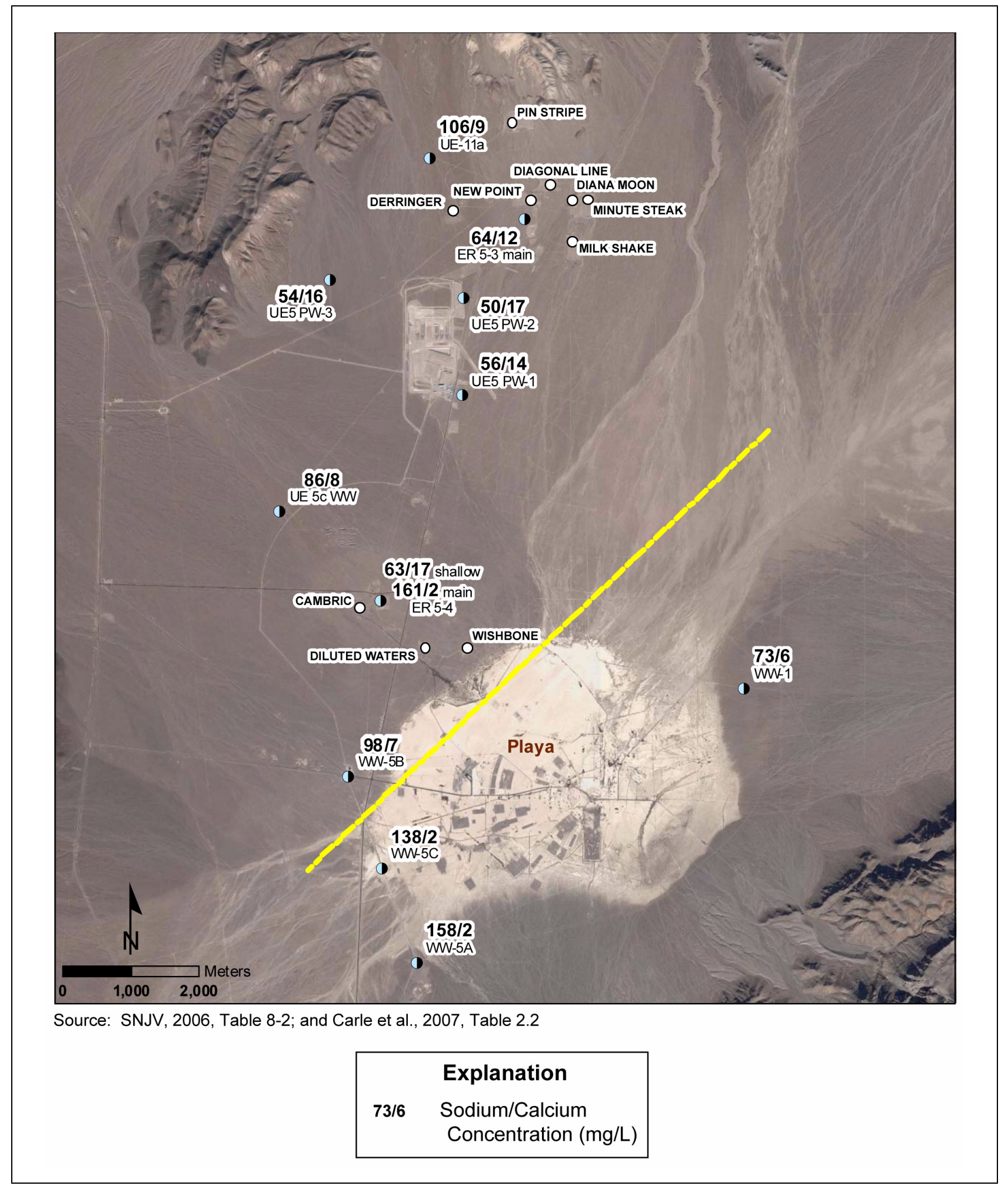

Figure 3-8

Sodium and Calcium Concentrations in Groundwater, Frenchman Flat 
Table 3-1

Water-Quality Data from RNM-2S and ER 5-4

\begin{tabular}{|c|c|c|c|c|c|}
\hline Well & $\begin{array}{c}\text { Screened Depth } \\
\text { below Water Table } \\
(\mathbf{m})\end{array}$ & $\begin{array}{c}\text { Alkalinity } \\
\text { (mg/L) }\end{array}$ & $\begin{array}{c}\text { Chloride } \\
\text { (mg/L) }\end{array}$ & $\begin{array}{c}\text { Sodium } \\
\text { (mg/L) }\end{array}$ & $\begin{array}{c}\text { Calcium } \\
\text { (mg/L) }\end{array}$ \\
\hline \hline RNM-2S & $0-65$ & 168 & 14 & 63 & 17 \\
\hline ER 5-4 & $\begin{array}{c}302-447 \\
\text { and 698 - } 917\end{array}$ & 319 & 27 & 161 & 2 \\
\hline
\end{tabular}

$\mathrm{mg} / \mathrm{L}=$ Milligrams per liter

- The chloride concentration at the downgradient Well WW-5C is significantly less than the chloride concentration at the upgradient Well WW-5B, which is apparently inconsistent with groundwater flow from WW-5B to WW-5C driven by the head difference.

Alkalinity concentrations in groundwater in Frenchman Flat fall into two classes: groundwater with alkalinity concentrations between 150 and $200 \mathrm{mg} / \mathrm{L}$ and wells with alkalinity concentrations greater than $300 \mathrm{mg} / \mathrm{L}$. In the latter group is Well ER 5-4, a well screened more than $300 \mathrm{~m}$ below the water table, and Wells WW-5A and WW-5B, which are both located in the southeastern portion of Frenchman Flat. The other well in the southeastern portion of Frenchman Flat, WW-1, does not have a reported alkalinity concentration. Thus, the alkalinity data also suggest a dichotomy in groundwater quality between the northwestern and southeastern portions of Frenchman Flat.

\subsubsection{Use of Groundwater Age in NHA Model}

The estimated groundwater ages interpreted from geochemical data were used to calculate the rates and directions of groundwater flow in the alluvium and these rates and directions were subsequently used as targets in the calibration of the NHA model. The rates and directions of groundwater flow used as calibration targets were determined from groundwater ages at the five well pairs shown on Figure 3-10. The groundwater velocities that were determined from the groundwater ages vary from 0.19 meters per year $(\mathrm{m} / \mathrm{yr})(190 \mathrm{~m} / 1,000 \mathrm{yr})$ to $1.1 \mathrm{~m} / \mathrm{yr}(1,100 \mathrm{~m} / 1,000 \mathrm{yr})$. These groundwater velocities are larger than the velocities estimated from the water-level data at the pilot wells (30 to $150 \mathrm{~m} / 1,000 \mathrm{yr}$ ).

The five well pairs used to calculate the rates and direction of groundwater flow were chosen because they were considered to likely lie along groundwater flow paths and because differences in 


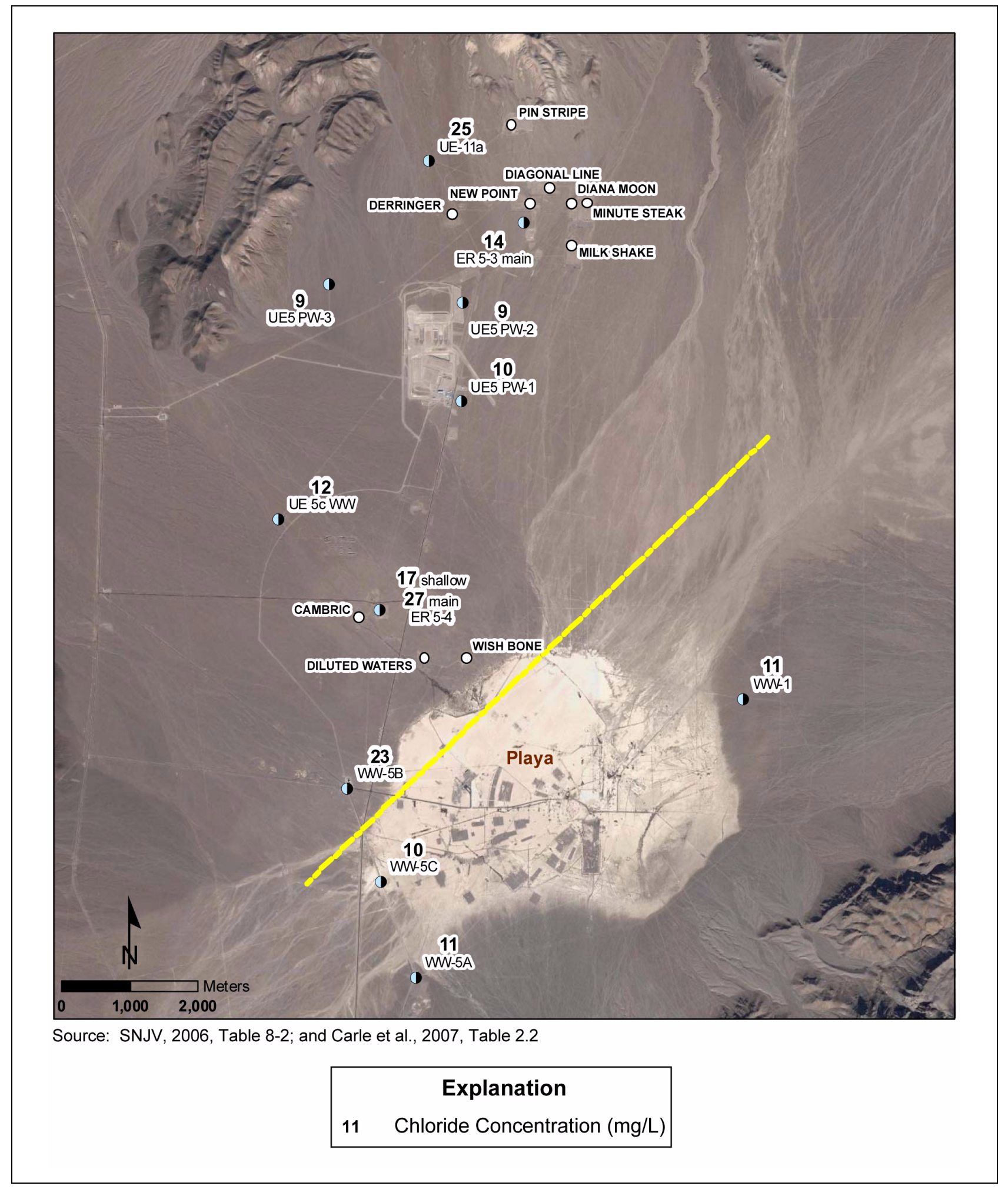

Figure 3-9

Chloride Concentrations in Groundwater, Frenchman Flat 


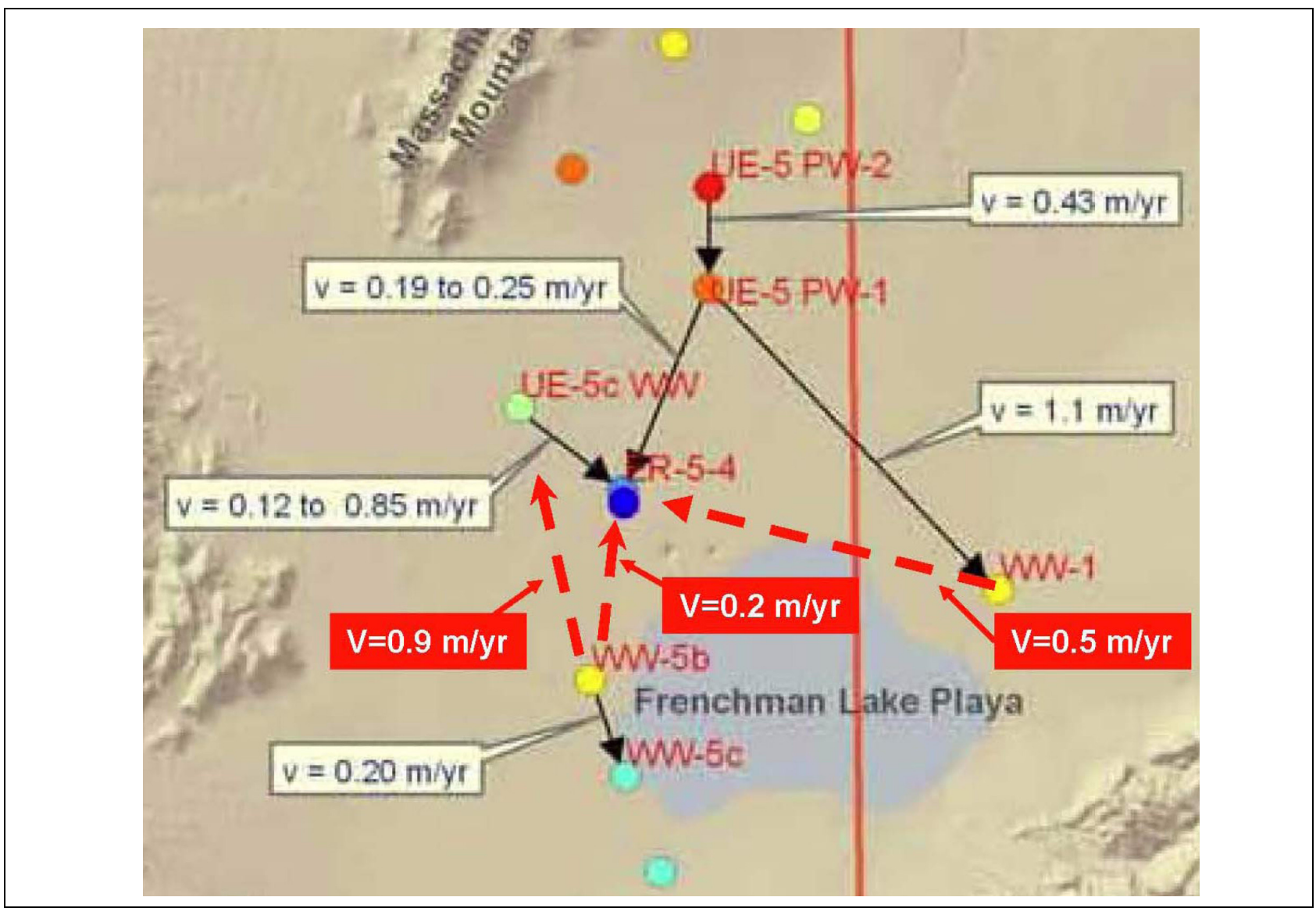

Figure 3-10

Groundwater Directions and Velocities as Calculated from Groundwater Age Note: Velocities with white backgrounds calculated between well pairs joined by solid black lines are from SNJV (2006, Figure 8-19). Velocities with red backgrounds calculated between well pairs connected with dashed red lines were calculated by peer review.

groundwater chemistry between wells were consistent with models of groundwater quality evolution. As noted in SNJV (2006):

"... it is likely that groundwater in the tuffs and alluvium flows south or southeastward from the recharge areas in the hills along the northern and northwestern perimeter of the basin toward the basin center. Using this general constraint on groundwater flow paths, groundwater velocities were calculated between pairs of wells."

Because the well pairs used to calculate groundwater flow directions and rates were selected with a general constraint on flow directions, it cannot be concluded that the flow directions calculated with the geochemical age data provide an independent estimate of the direction of groundwater flow.

Without this general constraint, many other pairs of wells could have been selected for calculating the 
rate and direction of groundwater flow because groundwater ages do not gradually increase in age from the northwest to the southeast in Frenchman Flat.

Figure 3-10 shows directions and rates of groundwater flow calculated by the peer review team from an additional three well pairs. The directions of flow calculated from these well pairs are to the west and north, which differ significantly from the flow directions used as targets in calibration of the NHA model. The peer review team did not check, using a geochemical modeling code, whether the geochemical differences between the wells in these additional three pairs were consistent with evolutionary trends, but an examination of the water-quality data suggests that they likely are. As a result, the peer review team is of the opinion that the rates and direction of groundwater flow calculated from the groundwater age data were inappropriate information to use in the calibration of the NHA groundwater model, as they do not provide independent information on direction of groundwater flow.

As a consequence, the peer review team is of the opinion that statements made in the Phase II documents regarding the use of the geochemical data are inappropriate. These statements include the following:

"The geochemical data, generally more so than the head and flux data, influence predictions of groundwater fluxes through the cavity." (NNES, 2010a, page 7-21)

"... the geochemistry data provide considerable information to constrain the simulated cavity flows.” (NNES, 2010a, page 7-21)

\subsection{Permeability Data}

The peer review team reviewed selected hydraulic tests in boreholes that have been used to estimate the permeabilities of the alluvial sediments and volcanic rocks in Frenchman Flat, and found that the methods used are consistent and appropriate with practice and with the geologic setting. The interpreted values of permeabilities from the hydraulic tests conducted in Frenchman Flat are summarized in SNJV (2004, Tables 5-1, 5-2, and 5-3) and in Carle et al. (2007, Figure 4.3). Some general observations on the permeabilities in the alluvium and the older altered (zeolitized) alluvium in the calibrated groundwater models are discussed in the following text. 
In the model calibration process, an initial reference permeability and a permeability depth-decay coefficient were assigned based on a review of the available estimates of permeability (SNJV, 2006, page 5-17). The effective hydraulic conductivity at the water table in the alluvium in the Central Testing Area based on these initial values is about $76 \mathrm{~m} / \mathrm{d}$ and in the older alluvium at the Northern Testing Area is about $34 \mathrm{~m} / \mathrm{d}$. How these initial values were derived from the testing data are not explained in the Phase II documents.

The effective hydraulic conductivity values obtained in the model calibrations were much lower than the initial values. The hydraulic conductivities at the water table in the alluvial aquifer in the calibrated models used to calculate the contaminant boundaries in the vicinity of the Central Testing Area were approximately as follows ${ }^{6}$ :
BASE-USGSD alternative model
$3.1 \mathrm{~m} / \mathrm{d}$
DISP-USGSD model
$8.6 \mathrm{~m} / \mathrm{d}$
BASE-USGSD with no depth decay model
$2.6 \mathrm{~m} / \mathrm{d}$

The total range in calibrated hydraulic conductivities for the alluvium at the Central Testing Area in the three models was only about a factor of three, from 2.6 to $8.3 \mathrm{~m} / \mathrm{d}$.

The hydraulic conductivities at the water table in the OAA in the calibrated models used to calculate the contaminant boundaries in the Northern Testing Area were as follows?
NHA Model
$0.2 \mathrm{~m} / \mathrm{d}$
BASE-USGSD alternative model
$0.3 \mathrm{~m} / \mathrm{d}$

These hydraulic conductivities for the older alluvium in the Northern Testing Area are about a factor of three to five lower than that used in the analysis of groundwater flow in the vicinity of the Area 5 RWMS (BN and Neptune, 2006). The low hydraulic conductivities in the older alluvium in the Northern Testing Area have been attributed to pervasive zeolitization of the older alluvium (BN, 2005a).

6. The hydraulic conductivities in the Central Testing Area are based on a water table depth of $220 \mathrm{~m}$ below ground surface. These hydraulic conductivities were based on the models calibrated to the RNM-2S multiple well aquifer test (NNES, 2010a, Section 5.0). In the original model calibrations described in SNJV (2006), the hydraulic conductivities at the water table in the three model were significantly lower: $1 \mathrm{~m} / \mathrm{d}, 2 \mathrm{~m} / \mathrm{d}$, and $5 \mathrm{~m} / \mathrm{d}$, respectively.

7. The hydraulic conductivities for the older alluvium in the Northern Testing Area are based on a water table depth of $283 \mathrm{~m}$ below ground surface. 
The peer review team has struggled with the appropriateness of a single-value representation of the hydraulic conductivity in the alluvium at and near the water table in the groundwater models used to calculate the contaminant boundaries. The opinion of the peer review team is that use of a single value of permeability in the alluvial layers may have resulted in an underestimation of rate of groundwater movement on a local scale because of potential omission of preferential flow pathways.

In addition, the peer review team has struggled with the appropriateness of using the boundary conditions derived from the Frenchman Flat CAU models in the sub-Central Testing Area models used for calculating the contaminant boundaries. The permeabilities (and hydraulic conductivities) used in the submodel are significantly larger than the permeabilities calibrated in the CAU models. As noted in NNES (2010b, page 5-21) the boundary conditions assigned in the submodels result in groundwater fluxes through the model area that are much larger than those in the CAU models. These higher fluxes create a water balance inconsistency between the CAU model and the submodel. Thus, the boundary conditions are not appropriate for the permeabilities that are specified.

\subsection{Geologic Data and Hydrostratigraphic Framework Model}

The previous peer review panel suggested collecting additional data to better define the hydrostratigraphic framework and recommended exploring alternative conceptual models that might create the potential for localized vertical flows from the alluvium through the volcanic confining units into the LCA driven by the head difference between it and the alluvium (IT, 1999). As noted previously, in response to this review, there was a concerted data collection effort during Phase II, involving well drilling; hydraulic testing; geochemical investigations; and various geophysical surveys, including a detailed 3-D seismic profiling spanning the two test areas. Integration and interpretation of the new data greatly refined and constrained the interpretation of the subsurface beneath Frenchman Flat, including a much greater depth of alluvium, a greater thickness of volcanic units, and a detailed 3-D faulting pattern than in the previous interpretation.

In evaluating the HFM and its hydrologic flow implications, the peer review team concluded that the interpreted geologic framework of Frenchman Flat and, in particular, the subsurface geology and structure is rigorous and well-constrained. With one exception noted below under recommendations (related to delineating the lateral extent of the basalt layer in the alluvium), probably not much more could be done to better understand and constrain the subsurface geologic structure. 
The peer review team also noted that conservatism was built into the HFM in a number of ways. For example, every fault identified by the geologists that seemed to control topography and structural grain, both at the surface and in the subsurface, was included in the HFM. This allowed the hydrologic modelers the opportunity to calculate the sensitivity of the flow model to a range of parameters for every possible fault.

In addition to the base HFM, four viable alternative HFMs were developed (after evaluation of 28 alternative interpretations; BN, 2005a, Table 5-1). The four alternatives created potential fast pathways for fluid migration. Only one of them, HFM Alternative \#1 (BN, 2005a, Section 5.2), involving a continuous basalt layer in the alluvium beneath the MILK SHAKE test, was found to play a potentially significant role in controlling contaminant transport. In this alternative, the basalt layer in the alluvium directly beneath the MILK SHAKE test is extended eastward nearly 2 kilometers $(\mathrm{km})$ as a single, continuous lava flow to the main basin-bounding fault (fault 33). While this eastward extension represents the most conservative interpretation of this unit in the subsurface, the peer review team feels it is a reasonable interpretation. As noted in Bechtel Nevada (BN) (2005a), many of the basalt lava flows in the NNSS region are closely associated with basin-bounding faults, so fault 33 conceivably could have been the source for this lava flow in the alluvium.

The Phase II project team explored the role of faulting in the HFM through a range of alternate models of fault structure and variation of fault properties in different rock and alluvial units. In the end, only two fault zones (Cane Spring and Rock Valley) were found to play any significant role in the groundwater system. These two fault systems play distinct roles in the flow model as summarized below:

1. The northeast-striking, normal-oblique Cane Spring fault (fault 3) forms the boundary between Frenchman Flat and CP Basin and effectively acts as a groundwater barrier to maintain the approximately 100-m difference in water-table elevations between the two basins. It was modeled as having a permeability at least seven orders of magnitude lower than the hydrostratigraphic units it cuts (NNES, 2010b, Table 6-3).

2. The oblique-normal slip Rock Valley fault system (consisting of multiple strands, faults 38 , 34,33 , and 21) is the major basin-bounding fault zone, forming the southeast margin of Frenchman Flat. This fault could potentially provide a pathway to connect the alluvial aquifer with the LCA by enhanced permeability along the fault plane and/or by a dramatic thinning of the volcanic confining units across the various strands of the faults. The Rock Valley fault systems is interpreted to have been active during deposition of the volcanic units, resulting in 
the thickness of the confining units thinning from $800 \mathrm{~m}$ in the deepest part of the basin to only about $50 \mathrm{~m}$ on the upthrown (southeast) side of fault 21 (NNES, 2010b, Plate 1, Section D-D').

3. A range of permeabilities and subsurface structures were explored for the principal strands of the Rock Valley fault zone. For a wide range of scenarios, the major fault strands (those with the greatest displacement, faults 33 and 34) were found to be essentially neutral, or have only minor permeability enhancement relative to surrounding hydrostratigraphic units at discrete depth intervals. The HFM Alternative \#3 (BN, 2005a, Section 5.2) maximized displacement on fault 34 and placed volcanic aquifer units in direct contact with the LCA along the fault). In this alternative model, the permeability was enhanced within the volcanic hydrostratigraphic units; however, at all other depths, the fault was specified as a slight barrier $\left(f_{\text {perm }}\right.$ factor $\left.<1\right)$. Thus, while a wide range of fault permeabilities was explored, it appears that thinning of the volcanic confining units by faulting during deposition plays a more important role than the permeability of the Rock Valley fault zone in the flow of groundwater from the alluvium to the LCA.

The review team did have several concerns regarding the HFM:

1. While the interpreted east-west continuity (despite potential fault disruptions) of a band of dipping volcanic aquifer units at the water table beneath the Northern Testing Area represents a conservative interpretation in terms of potential fast pathways, the review team felt that other aspects of this interpretation are not conservative. In particular, the interpreted eastward termination of this east-west band of volcanic aquifer units occurs less than $500 \mathrm{~m}$ short (west) of fault 33. This truncation or pinchout is significant because fault 33 provides a potential direct contact for these volcanic aquifer units with the LCA rocks. The area of the interpreted pinchout or truncation is in an area of complex 3-D geology and outside of the coverage of both the drill hole and seismic data.

As noted in the NNES (2010b) report, some contaminant boundary calculations for PIN STRIPE (which was detonated in these volcanic aquifer units at the water table) "show the possibility for rapid migration eastward to the edge of the alluvial/volcanic basin into the $L C A$." As a result, 10 alternate geometries for this eastern truncation of the volcanic aquifer units were explored using total system modeling described in NNES (2010b, Appendix D). Surprisingly, none of the alternatives explored a potential direct connection of the volcanic aquifer units with the LCA at fault 33; all alternatives evaluated had intervening tuff confining units. The peer review team notes that regardless of the true eastward extent of the volcanic aquifer units, the modeled maximum eastward extent of the PIN STRIPE contaminant boundary is only about $1,600 \mathrm{~m}$, far short of the approximately $3,100 \mathrm{~m}$ to fault 33 and the nearest contact with the LCA. This lack of conservatism in the geologic interpretation therefore probably does not impact the contaminant boundary, provided the permeability/conductivity estimates truly represent the full range of uncertainties. 
2. The review team also questions whether treating the alluvium as uniform, continuous layers in Frenchman Flat adequately captures the uncertainty in hydraulic properties in the alluvium. In BN (2005a), the geologists describe the alluvial deposition in the form of fans that coalesce in a complex 3-D pattern to form discontinuous, gradational, and poorly sorted deposits. Eolian sand, basalt flows, and older playa deposits (all with very different hydraulic conductivities) are found within the alluvial section (BN, 2005a). The Phase II documents cite drill-hole information from Area 5 RWMS and hydrologic data to assert that the alluvium is isotropic in a horizontal plane with respect to hydrologic properties.

The Northern Testing Area is located at the northern margin of Frenchman Flat, very close to the mountain masses of French Peak and Massachusetts Mountain. Alluvial and colluvial deposition in this basin margin setting could have much more variability than the lower energy depositional environment further into the basin interior. Specifically, with the east-west normal faulting and southward down-warping in this northern region, the possibility of approximately north-south trending stream gravel pathways of increased permeability would seem to be likely within the alluvium. Despite all its complexity, the hydrologic modeling did not explore small scale variations in permeability within the alluvium, the most important hydrostratigraphic unit controlling the contaminant migration. Interestingly, the project team did consider variability within the alluvium for their total systems modeling reported in NNES (2010b, Appendix D). Their scenario 8 specifically involved "increasing the conductivity/transmissivity values for the AA. The AA may be more gravelly in this area, and thus more permeable." To address this possibility, "the average AA velocity was doubled, to reflect the conceptualization of a more transmissive AA."

3. Despite all the detail and complexity in the faults in the HFM, no fault identified and modeled in the subsurface could be confidently linked to the rather abrupt water-level change that occurs in the southeastern portion of the playa. As discussed above in the observational data section, both the head change as well as geochemistry data define an approximately northeast-trending major groundwater barrier separating two distinct groundwater populations. Surface fault scarps along the Rock Valley fault system occur nearly $3 \mathrm{~km}$ southeast of this inferred boundary. Acknowledging that there is some uncertainty in the actual location of the faults in the subsurface, it seems surprising that there is nothing in the model that would account for the two dichotomous groundwater populations. This omission raises some concern about the completeness and fidelity of the HFM to the rather meager observational dataset, despite all the model complexity included. 


\subsection{Groundwater Budget Synthesis}

The peer review team developed a conceptual model of the Frenchman Flat alluvial system (Figure 3-11) to aid in its understanding of the groundwater models used to calculate the contaminant boundaries. This conceptual model, which is based on the groundwater model and the hydrostratigraphic models developed by the project team, represents a simple water budget for Frenchman Flat. In the conceptual model, groundwater potentially flows into the Frenchman Flat alluvium, and the volcanic units overlying the Wahmonie confining unit, from recharge on Massachusetts Mountain to the north, from the CP basin to the northwest, and from the Wahmonie Hills to the west. No groundwater inflows occur from the east or the south of Frenchman Flat because the water table in these areas is in the LCA (Figure 2-2). In addition, the long-term gradual decline of the water table in Frenchman Flat releases water from storage, which acts as an addition of water to the groundwater system. Groundwater outflow from the alluvium occurs primarily along the Rock Valley fault zone, but also along the eastern and southern perimeters of Frenchman Flat basin where the underlying volcanic rocks are thinner. In this conceptual model, groundwater flow in the alluvium is from the northern and western perimeters of the basin towards the southeast.

Groundwater models at their core are water-budget models. The water-budget model for the alluvial aquifer, and the upper portion of the Tertiary-aged volcanics, in Frenchman Flat can be expressed as:

$$
Q_{\text {Mass }}+Q_{C P}+Q_{W}+Q_{S}=Q_{L C A}
$$

where:

$Q_{L C A}=$ outflow to the LCA

$Q_{\text {Mass }}=$ inflow from recharge on Massachusetts Mountain

$Q_{C P}=$ inflow from the $\mathrm{CP}$ basin

$Q_{W}=$ inflow from the Wahmonie Hills

$Q_{S} \quad$ = inflow from change in storage due to a declining water table and drainage of the unsaturated zone 


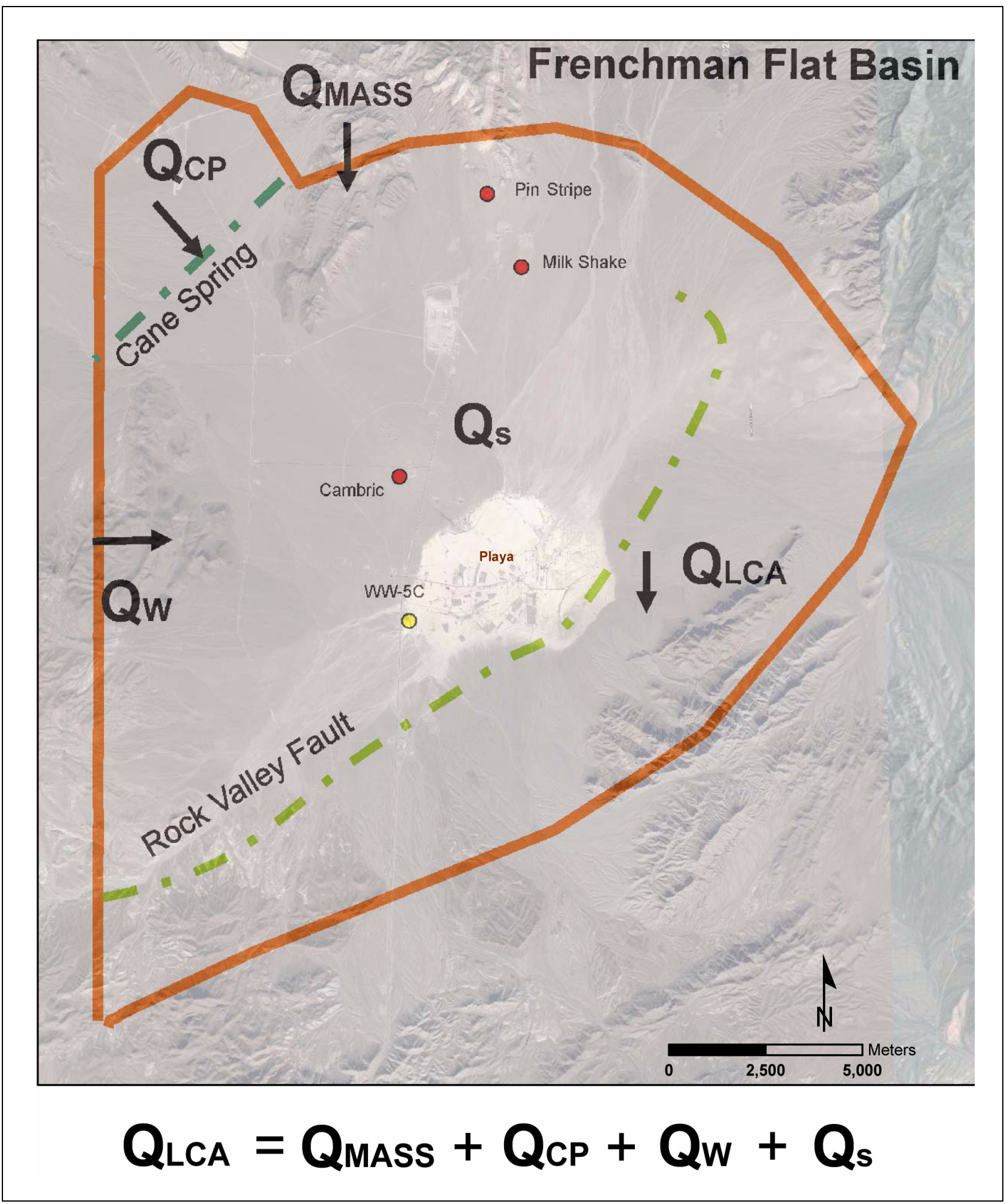

Figure 3-11

Conceptual Model of Groundwater Flow in Frenchman Flat 
The peer review team has the following observations regarding the water budget for the groundwater models developed as part of the Phase II studies:

- The water released from storage as the water table declines $\left(Q_{S}\right)$ is not considered, as water levels are assumed to be at a constant steady-state condition.

- The inflow from CP basin $\left(Q_{C P}\right)$ is implicitly calculated in the flow model based on constant head boundaries and hydraulic properties, but the peer review team finds that there is little if any data to define the magnitude of the flow.

- The inflow from recharge in Massachusetts Mountain $\left(Q_{\text {Mass }}\right)$ is only non-zero in the Northern Hydrologic Analysis model where the term is equal to the recharge that occurs on Massachusetts Mountain (NNES, 2010a, Figure 6-44). The peer review team is of the opinion that there is significant uncertainty as to magnitude of recharge on Massachusetts Mountain and whether or not potential recharge on Massachusetts Mountain flows into the alluvium into Frenchman Flat.

- The inflow term $\left(Q_{W}\right)$ comprises two parts: recharge on the Wahmonie Hills, and inflow from the constant head western boundary of the model area. The peer review team is of the opinion that there is little if any data to define the magnitude of this latter flow.

- The magnitude of the inflow terms are not discussed in any of the Phase II documents and are difficult to calculate with the flow code that was used for the modeling analyses.

The peer review team is of the opinion that the water balance of the volcanic rocks and alluvium overlying the Wahmonie confining unit should be explicitly considered and calculated in the models used for computing the contaminant boundaries. The reasonableness of the magnitude of these fluxes should be evaluated, and models in which these fluxes are unreasonable should be rejected. The magnitude and distribution of the boundary fluxes to a large degree determines the rate and direction of groundwater flow in the alluvium in Frenchman Flat. There are large uncertainties associated with these boundary fluxes that translate to uncertainties in calculated groundwater flow directions in the alluvium. The uncertainty in these boundary fluxes should be explicitly considered in the calculations of the contaminant boundaries. The peer review team is of the opinion that the magnitude of the inflow terms, with the exception of QS, in the Phase II models may be overestimated relative to actual flows because the modeling uncertainties were commonly addressed by choosing the options that tended to maximize flow rates. 


\subsection{Use of Models as Regulatory Decision tools}

The peer review team was charged with answering a series of specific questions regarding the modeling efforts for the Frenchman Flat CAU (Section 1.0). This section provides a general discussion on the use of mathematical models as regulatory decision tools to frame the peer review team's opinions on these review questions. The peer review team's answer to each question along with additional discussions is given in the subsequent three sections.

This section is based on a comprehensive exposition of the use of environmental models in regulatory decision making in a report published by the National Research Council (NRC) (2007). The report summarizes the basic steps in the model development process as definition of model purpose, specification of modeling context, conceptual model formulation, computational model development, model evaluation, and model use in regulatory context. While interested readers are referred to the original report for detailed information (NRC, 2007), the following paragraphs provide a synoptic review of the key points.

\subsection{Definition of Model Purpose}

It is imperative to have a clear goal for any model as it drives all the decisions in subsequent phases. A model is a simplification of reality and as such it is never complete. A model should never be expected to fully match the behavior of a real system; rather, it should be viewed as an "object" designed to fulfill the clearly expressed tasks (NRC, 2007, page 104). Thus, for the Frenchman Flat model, it is not important whether it can reproduce every detail of the observed flow and transport phenomena (it cannot). Much more relevant and critical is whether it fulfills the goal it was intended for as a tool to support regulatory decision making.

\subsection{Specification of Modeling Context}

After determining the purposes of the model, the modeler must develop specifications for the model context. This task involves addressing such issues as temporal and spatial scales of the model, 
intended model users and required expertise, type of input data and sources, availability of data to support model evaluation, desired outputs (deterministic or probabilistic), need for additional outputs to enhance model transparency and flexibility, required level of reliability, and applicable evaluation criteria to determine the model applicability. Thinking these issues through and dealing with them in a systematic and consistent manner can contribute significantly to the success of the modeling effort.

\subsection{Conceptual Model Formulation}

A conceptual model is a qualitative, and often graphical, description of a 3-D groundwater flow system depicting the general system structure and the relationships within the system that are known or hypothesized to be important. Formulation of a clear and effective conceptual model is key to successful model development and application. However, it is noteworthy that conceptual model formulation is not a "one-time deal." As the subsequent numerical model developed from the conceptual model is checked against the field measurements, it is likely that a significant mismatch will call for revisions to be made to the original conceptual model. Thus, conceptual model formulation is an iterative and adaptive process that reflects the interdependence of models and measurements.

An important consideration during conceptual model formulation is the principle of "model parsimony." As NRC (2007) points out: "Models used in the regulatory process should be no more complicated than is necessary to inform regulatory decisions. In the process of evaluating whether a model is suitable for its given application, there should be a critical evaluation of whether the model has been made unreasonably complicated. This evaluation should include how model developers and those that select a model for a particular application have addressed the trade-offs between the need for a given model application to be an accurate representation of the system of interest and the need for it to be reproducible, transparent, and useful for the regulatory decision at hand."

\subsection{Computational Model Development}

Computational model development is the stage where the previously formulated conceptual model - including the assumptions, processes, and input-output relationships - is replaced by mathematical terms and computer codes. This stage requires decisions about the appropriate model code, hardware platform, software infrastructure, parameter estimation, pre- and post-processing of 
model results, database management, and documentation of model history and revisions. A modular approach is preferred to computational model development because of its ability to easily add or remove parts of the model without affecting the others, thus creating models of different complexity.

\subsection{Model Evaluation, Testing and Revision}

In considering the process of model evaluation, testing and revision, NRC (2007) adopts the perspective that a model is a "tool" designed to fulfill a task - providing scientific and technical support in the regulatory decision-making process — not a "truth-generating machine." With this perspective, it is suggested that the following questions serve as the key considerations in model evaluation and application (NRC, 2007, page 108):

- Is the model based on generally accepted science and computational methods?

- Does it work; that is, does it fulfill its designated task or serve its intended purpose?

- Does its behavior approximate that observed in the system being modeled?

A crucial element in model evaluation and application is uncertainty analysis and related sensitivity analysis. Multiple approaches may be used to perform uncertainty and sensitivity analysis. While full-fledged probabilistic methods, such a full Bayesian analysis or Monte Carlo analysis, may be theoretically appealing and indeed necessary to quantity and communicate uncertainties under many circumstances, examining a small number of model scenarios in a deterministic manner may provide an adequate uncertainty analysis in other cases. The NRC (2007) also makes a critical distinction between the model uncertainty and parameter uncertainty. The former refers to the uncertainty in the model structure (alternative models) while the latter refers to the uncertainty in the model parameters. Model structure uncertainty is much more difficult to deal with and properly quantify than parameter uncertainty. However, model structure uncertainty can be a much bigger contributor to the overall uncertainty in a model than parameter uncertainty.

The NRC (2007) also recommends that the model developer strive for parsimony and transparency in the development and use of models. The former refers to the preference for the least complicated explanation for an observation, while the latter refers to the need for stakeholders and members of the public to comprehend the essential workings of the model and its outputs. The NRC (2007) further articulates that "parsimony does not justify simplicity for its own sake. It instead demands that a model capture all essential processes for the system under consideration-but no more." 


\subsection{Model Use in Regulatory Context}

In applying models to support an environmental regulatory issue, NRC (2007) stresses the need for model developers and regulators to evaluate how appropriate an existing model is for a specific setting and whether the assumptions and input data are relevant under the conditions of the application. In particular, it is important to understand the major assumptions and the range of applicability of a model because they define an application niche for a model. Moreover, it is important to have effective strategies for representing and communicating uncertainties. In particular, the modeler should be cautious about extrapolating far beyond conditions for which the model was constructed or calibrated or conditions for which the model outputs cannot be verified. In these circumstances, uncertainties about the form of a model and the parameters in the model might yield large uncertainties in model outputs. The NRC (2007, page 189) recommends that "when critical model parameters are estimated largely on the basis of matching model output to historical data, care must be taken to provide uncertainty estimates for the extrapolations, especially for models with many uncertain parameters." 


\subsection{ARe Modeling APPROACHES, Assumptions, AND RESULTS CONSISTENT WITH REGULATORY USE?}

The first question addressed by the peer review team is as follows:

Are the modeling approaches, assumptions, and model results for Frenchman Flat consistent with the use of modeling studies as a decision tool for resolution of environmental regulatory requirements?

The review team views this question in the context of whether the modeling approaches and assumptions employed by the project team and the model results obtained are overall consistent with the generally accepted scientific principles and recommended procedures in a regulatory framework. Detailed comments on the validity of specific approaches, assumptions and results are provided in other parts of this report. The question is addressed in the following three subsections.

\subsection{Modeling Approaches}

The various flow and transport models developed for the Frenchman Flat CAU can be summarized in Figure 5-1. The Frenchman Flat CAU flow and transport model is at the center of the Phase II model development efforts. The CAU-scale flow model simulated steady-state flow conditions. Its boundary conditions were constructed from and supported by two regional flow models primarily developed for the LCA flow system: the Phase I regional flow model (DOE/NV, 1997) and the U.S. Geological Survey (USGS) Death Valley Regional Ground-Water Flow System model (Belcher et al., 2004). Alternative HFMs and recharge distributions were defined to yield a total of 20 models, each of which was considered a plausible representation of the hydrogeologic conditions at Frenchman Flat.

A separate small scale model was developed of the area in the vicinity of the CAMBRIC test. This transient flow and transport model was used to simulate the long-term radionuclide migration experiment at RNM-2S and the multiple-well aquifer test. The permeabilities of the 


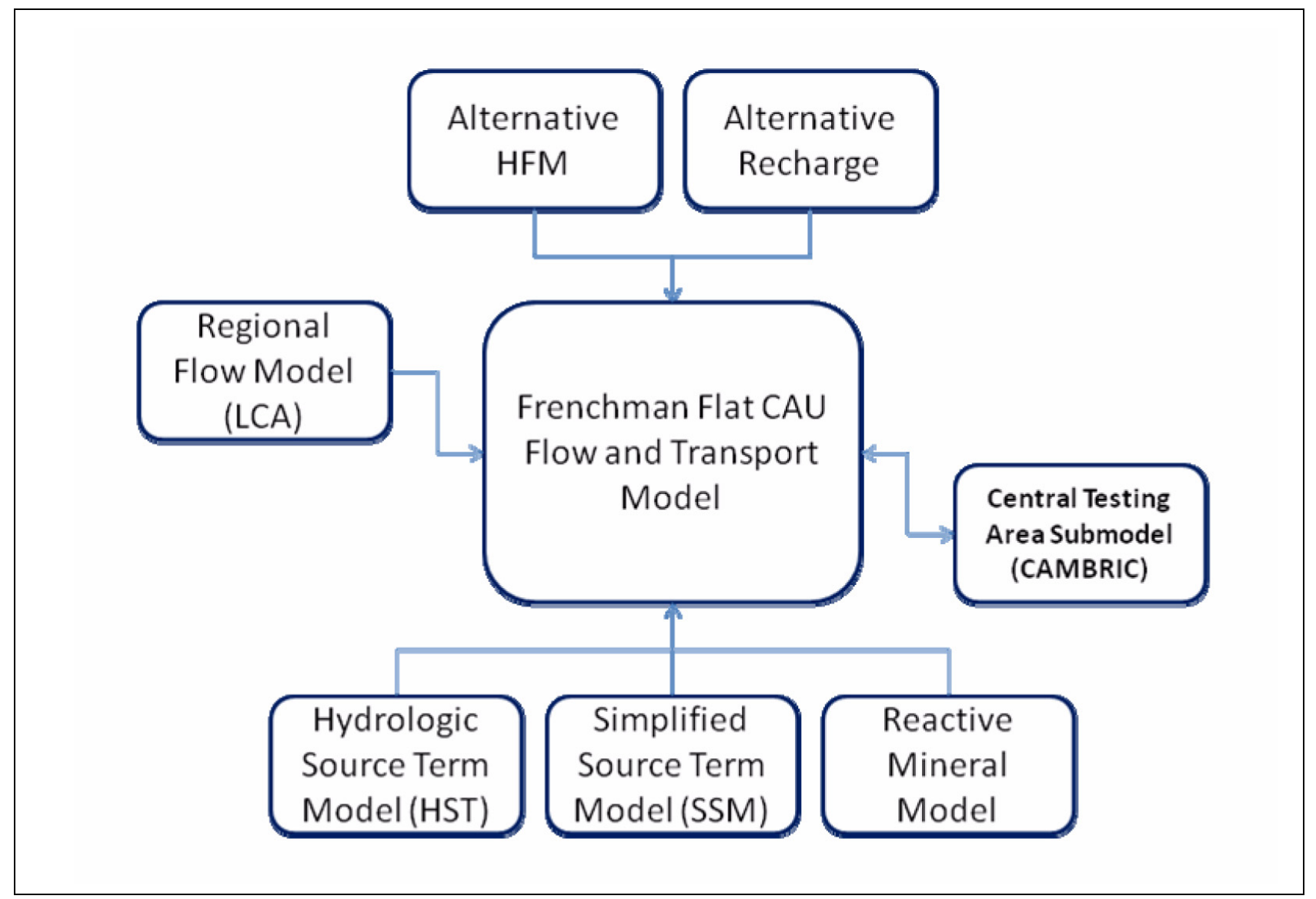

Figure 5-1

Relationship between Various Flow and Transport Models Developed for Frenchman Flat

hydrostratigraphic units estimated from the calibration of this model were used in a submodel of the Frenchman Flat CAU flow and transport model to calculate the contaminant boundaries for the CAMBRIC test and two other tests at the Central Testing Area and the radionuclide migration experiment. The boundary fluxes for the CAMBRIC model were interpolated from the CAU-scale model.

The hydrologic source term (HST) model was developed as part of detailed analyses to simulate radionuclide migration at the CAMBRIC site (Carle et al., 2007). It took advantage of more than 40 years worth of experimental data associated with the CAMBRIC test. The HST model simulated the radionuclide migration from the time the test was conducted in May 1965 to the present time. A sophisticated procedure was developed to approximate the release of radionuclides from the source area (including the explosion cavities), migration through the alluvium, and discharge into the 
pumping Well RNM-2S. The model was constrained reasonably well by the long-term water-quality data at Well RNM-2S, which was pumped from 1975 to 1991 at an average rate of about 600 gallons per minute. A version of the HST model, stripped of the complex near-cavity processes, became the basis for the Central Testing Area submodel.

The simplified source term model (SSM) was an attempt to reduce the complexity of the near-cavity processes that control the radionuclide source release while capturing and retaining their key characteristics. A one-dimensional transport model based on the GoldSim software (GoldSim, 2006) was used to conceptualize and simplify the source term for the CAMBRIC test, from which a simplified source term was derived that can be used for other tests based on simple input and output relationships. Because the SSM was derived from the CAMBRIC test (located in the saturated alluvium), additional source term conceptualization and approximation was attempted for the PIN STRIPE test (detonated in volcanic tuff) and the MILK SHAKE test (located in alluvium but above the water table). Detailed unsaturated flow and transport modeling was conducted to obtain the source terms that would be subsequently used in the CAU-scale model to delineate the contaminant boundaries for these tests.

The reactive mineral model was developed to characterize the mineralogy of the rocks in the vicinity of each nuclear test to quantify the presence and abundance of minerals known to have absorptive and reactive attributes important to radionuclide transport processes. From the HFM, each hydrostratigraphic unit was further subdivided into multiple reactive mineral categories (RMCs). Mechanistic sorption modeling was then carried out to determine the distribution coefficient $\left(\mathrm{K}_{\mathrm{d}}\right)$ values associated with different RMCs. The $\mathrm{K}_{\mathrm{d}}$ values determined this way were used in the CAU-scale transport model in contaminant boundary delineation.

The modeling approach adopted by the project team is based on generally accepted science and computational methods. The model development efforts have generally followed the basic procedures recommended by NRC (2007) and described in Section 4.0. The modeling objectives were stated as follows:

- To identify nature and extent of groundwater contamination resulting from radionuclides produced during nuclear weapons testing. 
- To simulate the flow and contaminant transport for 1,000 years to delineate contaminated groundwater.

- To quantify boundaries around each UGTA CAU within which water may be unsafe for domestic and municipal uses.

These objectives address narrowly defined, specific issues in a regulatory framework rather than seek the absolute truth about what will happen to radionuclide contaminants at Frenchman Flat 1,000 years from now, which is unattainable. The modeling strategies employed by the UGTA subproject have involved the following steps:

- Developing conceptual geological framework and alternate models.

- Developing hydrologic and radionuclide source terms.

- Developing regional flow models to provide constraints and boundary conditions for CAU-scale flow and transport models.

- Developing CAU-scale flow and transport models.

- Calibrating and revising CAU-scale flow and transport models using hydrologic and geochemical data.

- Conducting sensitivity analysis of key model input parameters, controlling processes, and source terms.

- Conducting uncertainty analysis of both model structures and model parameters.

- Delineating probabilistic contaminant boundaries for regulatory compliance.

- Determining intended use of the compliance boundaries for site closure negotiation and institutional controls.

These steps reflect the recommendations of NRC (2007) both in substance and in spirit. The review team concludes that the modeling approaches employed in the UGTA subproject are overall consistent with the use of models as a decision tool for resolution of environmental and regulatory requirements.

However, the peer review team also feels that the modeling team has perhaps over-relied on the use of sophisticated numerical modeling approaches at the expense of less complex and more transparent 
methods that may reveal significant insights into the problems at hand. For example, the peer review team believes it would be worthwhile and instructive to start from the first principles applying Darcy's Law and using the measured water level, hydraulic conductivity, and effective porosity data to estimate the approximate contaminant boundaries for each underground nuclear test. The semi-qualitative estimate made this way would provide a constraint and check on the outcome of sophisticated 3-D numerical models whose uncertainties may be difficult to quantify precisely.

\subsection{Model Assumptions}

A model is a simplification of reality. As such, many simplifying assumptions are inevitable to make it feasible to represent the highly complex field conditions at Frenchman Flat in a numerical model. While some assumptions that have been made and embedded in the various flow and transport models developed at Frenchman Flat are subject to questions, as discussed in more detail in Section 3.0, the peer review team is of the opinion that most of the model assumptions are reasonable, justifiable, and consistent with the use of models as a decision tool for resolution of environmental and regulatory requirements.

One issue of potential concern is the assumption of spatial invariance in the hydraulic conductivity and porosity values for each hydrostratigraphic unit. In general, the uncertainty analysis has only considered a limited range of spatially uniform hydraulic conductivity and porosity values, leaving open the possibility that the uncertainty in the spatial distribution of these key model input parameter has not been sufficiently explored. For example, what is the likelihood of connected preferential flow channels occurring in the alluvial aquifer? If such possibility cannot be readily eliminated, what is its impact on the delineation of contaminant boundaries?

Another model assumption that is subject to question is steady-state groundwater flow. From water-level data available (e.g., Wells UE-5 PW-1, UE-5 PW-2, and UE-5 PW-3), it appears that the water levels at Frenchman Flat are declining at a rate close to $1 \mathrm{~m} / 100 \mathrm{yr}$. If the flow system in the alluvial aquifer is transient as it appears to be, then the release of water from the aquifer storage could be a significant component of the water budget for the alluvial aquifer.

Finally, an assumption that deserves further scrutiny is that the total radioactive inventory for the Frenchman Flat CAU can be divided by 10 to obtain the source term for each individual test. 
While this assumption simplifies modeling tasks, it may substantially underestimate the strength of the radioactive source term for a particular test, thus underestimating the calculated contaminant boundary.

\subsection{Model Results}

The primary outcome of the UGTA modeling efforts is presented in terms of 1,000-year contaminant boundaries for radionuclides with a 95 percent confidence interval (i.e., anywhere beyond the delineated contaminant boundaries there is less than a 5 percent chance of exceeding the Safe Drinking Water Act standards [CFR, 2009] for beta emitters, alpha emitters, and uranium at any time over the next 1,000 years). The contaminant boundaries expressed in confidence interval have integrated most of the uncertainties in the geologic conceptual models and hydrologic parameters that can be readily quantified. This probabilistic representation of contamination risks is consistent with the use of a modeling tool to aid in the decision-making process, as articulated in NRC (2007). The calculated contaminant boundaries are shown on Figures 2-3 and 2-4.

As previously discussed, NRC (2007) recommends that the model developer strive for parsimony and transparency in the development and use of models. The principle of parsimony requires that a model capture all essential processes for the system under consideration, but no more. In the judgment of the peer review team, this goal has been achieved to some extent, but not completely. Recommendations for model improvements are given in Section 9.0.

The peer review team also feels that there is somewhat of a disconnect between data exploration and numerical modeling. Because of the complexities of the numerical models and ambiguities in the data, it is often difficult to evaluate whether the models' behaviors approximate those observed in the system being modeled. Under such circumstances, it is advisable to invest more time and effort exploring and discerning the real trends and implications in the existing data. Such information can be used to frame the numerical models. Conversely, the information gained from data interpretation and analysis serves as the targets and constraints for model calibration and confirmation.

In addition, the peer review team feels there may be a disconnect between local- and regional-scale studies. While much thinking and effort has gone into establishing the uncertainties in the regional-scale models with alternative geologic and hydrologic frameworks, the uncertainties in some 
local-scale geologic variabilities and hydrologic parameters may not have been examined in sufficient detail. The peer review team recommends the modeling team better elucidate the relationship between the uncertainties in the regional-scale flow models and those in the local-scale transport models. 


\subsection{Do Modeling Results Adequately Account FOR UNCERTAINTY?}

The second question addressed by the peer review team is as follows:

Do the modeling results adequately account for uncertainty in models of flow and transport in the Frenchman Flat hydrological setting?

a. Are the models of sufficient scale/resolution to adequately predict contaminant transport in the Frenchman Flat setting?

b. Have all key processes been included in the model?

c. Are the methods used to forecast contaminant boundaries from the transport modeling studies reasonable and appropriate?

d. Are the assessments of uncertainty technically sound and consistent with state-of-the-art approaches currently used in the hydrological sciences?

The first two sub-questions ( $a$ and $b$ ) would require significant additional work to determine in a rigorous manner. The brief period allowed for the work of the peer review team precludes an in-depth review of all analyses performed at Frenchman Flat. For example, it was not possible to review the actual input files for the model, nor to run the model independently. Given these caveats, it is the opinion of the peer review team that the models used at Frenchman Flat are very high resolution and that a detailed evaluation of subsurface processes was undertaken by the project staff. However, the peer review team was concerned that several processes were not adequately addressed. For example, while the models are of high resolution, they did not account for the possibility of preferred pathways in the alluvial aquifer except in one scenario in the total systems modeling discussed in Section 3.5 (NNES, 2010b, Appendix D). It is possible in the alluvial fans to have channels of high hydraulic conductivity that could allow contaminants to migrate further than under the scenario of a relatively uniform hydraulic conductivity value. The peer review team also recognizes that data are limited in 
defining potential preferred pathways; however, there are ways to scope this problem (e.g., looking at spacing of drainages in the adjacent ranges).

All models used in the evaluation assumed steady-state groundwater flow. An analysis of water-level data at Wells UE-5 PW-1, UE-5 PW-2, and UE-5 PW-3 indicate a consistent trend of declining water levels of approximately $1.2 \mathrm{~m} / 100 \mathrm{yr}$. It is possible that instead of being driven by a uniform annual recharge from CP basin and/or Massachusetts Mountain, groundwater has steadily been declining since the last major recharge event in the basin. It is likely, however, that the steady-state assumption is conservative from a regulatory standpoint because as water levels drop into the future, the horizontal gradients will likely become lower.

The last two sub-questions ( $c$ and d) focus on the general issue of whether the contaminant boundary calculations were reasonable, appropriate, and state-of-the-art. The peer review team interprets "state-of-the-art" to mean the most advanced techniques that can be practically applied to a groundwater flow and transport model of a real site (i.e., other techniques may be available as research tools that have not been applied in the real world).

With the possible exception of the Yucca Mountain Project, the uncertainty analysis applied to Frenchman Flat goes far beyond any other project known to the peer review team members. The current standard practice at groundwater contamination sites is to perform a discrete sensitivity analysis or bounding calculation to bracket the model predictions. Uncertainty analysis is sometimes performed at larger federal facilities (e.g., Hanford, Washington), but not nearly as detailed as the analyses performed at Frenchman Flat.

In the 1990s, the American Society for Testing and Materials (ASTM) was funded by the U.S. Environmental Protection Agency (EPA), USGS, and the U.S. Department of the Navy to develop standards for a wide range of environmental analyses, including groundwater modeling. At that time, the consensus of the scientific community was that a predictive sensitivity analysis was adequate for determining uncertainty (ASTM, 2008). Even that level of detail was subject to the professional judgment of the modeler.

At about the same time that ASTM was developing standards for groundwater sciences, the Waste Isolation Pilot Plant (WIPP) in New Mexico was undergoing a performance assessment 
(Helton, 1998) that was ultimately presented to EPA in support of a permit application. These analyses for WIPP are analogous to the uncertainty analysis performed for UGTA but were not as detailed. The WIPP uncertainty analysis performed 600 realizations using one HFM, compared to thousands of realizations on several different HFMs at Frenchman Flat. The analysis at WIPP was performed more than 10 years ago, so given the changes in technology the Frenchman Flat uncertainty analysis would seem to be appropriate for a radioactive waste site.

In the 1990s, the focus of uncertainty analysis was on parameter uncertainty as in the WIPP analysis. Since that time, it has also become apparent that models should address conceptual uncertainty, such as in the underlying geologic framework (e.g., Poeter and Anderson, 2005). Another new approach by Tonkin and Doherty (2009) suggested that when evaluating uncertainty, the models should also achieve a certain degree of calibration. The uncertainty analysis applied to the Frenchman Flat flow and transport models used all of these techniques. In the opinion of the peer review team, this constitutes a state-of-the-practice analysis of uncertainty.

One problem the peer review team identified is that the level of detail in the uncertainty analysis makes it very difficult to understand. There should be some effort expended in providing a summary of the details of the uncertainty analysis, possibly in a spreadsheet format, so that the assumptions and results can be communicated more effectively. The peer review team had considerably difficulty in understanding the range of parameter values that were investigated in the sensitivity analyses.

The NRC (2007) summarized their opinion on model uncertainty as follows:

"Hybrid analyses combining aspects of probabilistic and deterministic approaches might provide the best solution for quantifying uncertainties, given the finite resources available for any analysis. For example, a sensitivity analysis might be used to determine which model parameters are most likely to have the largest impacts on the conclusions, and then a probabilistic analysis could be used to quantify bounds on the conclusions due to uncertainties in those parameters."

The uncertainty analysis applied to Frenchman Flat followed these guidelines, especially during transport uncertainty analysis where some simplification was required to achieve results in a reasonable time frame. 
Even with all of the complex analyses performed at Frenchman Flat, the ultimate goal is to make some decisions with regard to the future of the site and how it will be managed. The NRC suggests the following:

"Effective uncertainty communication requires a high level of interaction with the relevant decision makers to ensure that they have the necessary information about the nature and sources of uncertainty and their consequences. Thus, performing uncertainty analysis for environmental regulatory activities requires extensive discussion between analysts and decision makers."

It was obvious from the discussions in Las Vegas at the beginning of the peer review that the project team has a good working relationship with the regulator. This is probably one of the most important aspects of the project. 


\section{0 are Modeling Results adequate To Move to NeXt Stage?}

The third question addressed by the peer review team is as follows:

Are the datasets and modeling results adequate for a transition to CAU monitoring studies - the next stage in the UGTA strategy for Frenchman Flat?

Current guidance from NRC and EPA states that environmental models should evolve with site understanding throughout the process of managing the site. This guidance replaces the unobtainable goal of model validation with a process of model evaluation that builds confidence in model applications through iterative testing of model strengths and limitations (NRC, 2007; EPA, 2009). The UGTA strategy consists of building confidence in the site characterization and modeling through iterative testing of alternative representations of uncertain model components; collecting monitoring data; and extending the model over the characterization, analysis, and site closure processes (FFACO, 1996; as amended March 2010). The peer review team finds that the UGTA strategy is consistent with NRC and EPA guidance on the use of models for decision support in a regulatory context.

The next stage of the UGTA strategy is the CADD/CAP stage, which requires an initial estimate of the compliance boundary and guidance for the initial monitoring program (FFACO, 1996; as amended March 2010). The UGTA strategy requires that the site characterization should have built sufficient confidence that the models can be constructed, parameters inferred, and results corroborated. As discussed in the preceding sections, the site is geologically complex; the hydraulic gradient is negligibly small; the exploration depth makes data expensive to acquire; and the need for weapons security has restricted knowledge of the contaminant sources. Despite these difficulties in site characterization, the peer review team notes that the subsurface investigations of Phase II have yielded a sophisticated understanding of geology and have led to an improved understanding of the hydrostratigraphy and a set of plausible alternative models. Although significant uncertainties remain 
regarding site characteristics, source terms, and process processes remain, these are addressed through conservative choices that tend to maximize the extent of the simulated plumes. The peer review team concludes that site characterization data and understanding are adequate for constructing models for use in estimating an initial contaminant boundary and developing a monitoring design. The peer review team further notes that as site management progresses to the CADD/CAP stage, it is possible that additional data will lead to the evolution of site understanding and refinements of the initial contaminant boundary. This evolution is consistent with the UGTA strategy (FFACO, 1996; as amended March 2010) and with NRC and EPA guidance (NRC, 2007; EPA, 2009).

The present peer review team notes that the Phase II study analyses represent a complete reworking of the Phase I analyses, with an improved modeling method that incorporates the new observations, revised boundary conditions, recharge distributions, and alternative hydrostratigraphic models. The Phase II modeling approach also has been updated to include a state-of-the-practice Monte Carlo simulation within the uncertainty of the insensitive parameters, and the calibration has been constrained using the transport velocities inferred from geochemical data. However, despite the improved site characterization and advances in modeling of the Phase II analyses, the conclusions of the Phase I studies have not been radically altered; flow in the Frenchman Flat basin is generally to the southeast and is slow. The peer review team concludes that the project team has explored a wide range of variations in assumptions, methods, and data, which builds sufficient confidence in the models to proceed to the CADD/CAP stage. 


\subsection{Static Analyses}

The groundwater models used to calculate the contaminant boundaries assume uniform groundwater conditions at the site for the next 1,000 years. The peer review team understands that the selection of the 1,000-year time interval for regulatory compliance implicitly assumed static conditions and that that assumption dates back at least to the 1980s or 1990s. The 1,000-year compliance period at Frenchman Flat is in marked contrast to the 1-million-year regulatory framework that was required for Yucca Mountain.

However, new data and scientific understanding call into question the assumption of static conditions in the groundwater system for the next 1,000 years in Frenchman Flat. Potential impacts due to climate change and/or disruption by earthquake faulting of the two major controlling fault zones (Cane Spring and Rock Valley) in the flow system are not addressed in the report.

While static conditions may have been one of the starting assumptions for this project, one of the project principles presented to the peer review team was that as new knowledge accumulated, models would be revisited and possibly revised. Climate change could impact recharge and water levels both in the alluvial aquifer as well as in the regional carbonate aquifer at depth and possibly in different ways. Fracturing induced by earthquake faulting could introduce new potential pathways for groundwater flow or offset alluvial unit that could create barriers in the system. Some combination of the two effects could potentially perturb the flow system beyond the parameter space explored. It would seem a full exploration of uncertainty should include some brainstorming around low probability/potentially high-impact scenarios of which recent events (e.g., 9-11, Hurricane Katrina, and the BP oil spill/eruption) are conspicuous examples.

\subsection{Climate Change}

Past rationale for ignoring climate change over a 1,000-year time interval was based on an understanding of late Quaternary climate change cycles (super pluvial to arid with time periods of 
approximately 100,000 years.) However, in the last decade, accumulating data and scientific consensus (reports of the Intergovernmental Panel on Climate Change) indicate strong anthropogenic impacts on the global climate system with the potential for unprecedented disruptions and extremely rapid (on the scale of decades) "changes of state" of the climate system.

Numerous research groups have studied the regional impacts of climate change on the American Southwest. In the Rocky Mountain-Great Basin region of the southwestern United States (of which NNSS is a part), at least some models project that total precipitation for the region will increase by 50 to 100 percent (USGCRP, 2009b) ${ }^{1}$. Other projections generally indicate a more arid climate system throughout the southwest (USGCRP, 2009a). If precipitation does change significantly over the 1,000-year regulatory period, it would impact recharge rates both to the alluvial and the deeper regional aquifer. The magnitude of the impact on these two very different scale aquifers may be quite different.

While the peer review team suspects that climate change does not pose a problem in terms of impacting the groundwater flow models, the team is of the opinion that it is incumbent on the study team to at least do some scoping of this issue.

\subsection{Earthquake Faulting}

Throughout the Basin and Range province, ample evidence exists that the young normal faults provide major conduits for fluid flow. Most of this evidence comes from the numerous natural geothermal systems throughout the region that are located along basin-bounding fault zones and that provide rapid ascent of naturally heated waters from several kilometer depths to the surface. Studies of present-day state of stress and 3-D fracture distribution at depth were conducted in two wells in Yucca Mountain, using hydraulic fracturing and a borehole televiewer survey (Stock et al., 1985). Barton et al. (1995) analyzed a microthermal log run in one of the Yucca Mountain wells to identify which of the measured fracture planes were hydraulically conductive. The results of this microthermal analysis were combined with similar studies of the relationship of 3-D fracture distribution and stress state at depth from borehole studies in a variety of tectonic settings around the world. The results consistently indicate that the hydraulically conductive fractures at depth are those

1. (http://www.usgcrp.gov/usgcrp/nacc/education/rockies-greatbasin/rockiesandgreatbasin-edu-2.htm\#Future) 
oriented as "critically stressed faults" (i.e., those fractures optimally oriented for failure in the present-day stress regime) (Barton et al., 1995).

Fault permeability for the geothermal systems in the Basin and Range can be interpreted as related to a series of critically stressed faults with small (microearthquake-scale) movements. Microseismicity is, in fact, required to counteract the natural tendency for geochemical sealing of the fractures as the mineral-rich geothermal waters pass through the fractures and heal them. Microseismicity is also a ubiquitous property of natural geothermal areas (Eberhart-Phillips and Oppenheimer, 1984; Feng and Lees, 1998; Ward, 1972).

Stock et al. (1985) determined a normal faulting stress regime at depth (maximum principal stress vertical) with an $\mathrm{N} \sim 65^{\circ} \mathrm{W}$ least horizontal stress direction, consistent with seismicity and other active tectonics studies in the region. This $\mathrm{N} 65^{\circ} \mathrm{W}$ least horizontal stress direction is roughly perpendicular to the main Rock Valley fault zone and the north-northeast-trending normal faults fanning out into Frenchman Flat from it. The ongoing seismicity in and around the Rock Valley fault zone potentially is acting to create fracture permeability along that fault.

The Phase II project team also noted the critical role of faults as potential pathways for groundwater flow in Yucca Flat just to the north of Frenchman Flat (NNES, 2010a, p.3-9):

"A groundwater trough coinciding with the Yucca Flat fault suggests that groundwater in Yucca Flat drains preferentially through this fault toward CP basin and Frenchman Flat (Winograd and Thordarson, 1975; Laczniak et al., 1996). More recently, hydraulic data from an aquifer test in the LCA in Yucca Flat demonstrate a rapid hydraulic response at a monitoring well connected by a fault to the pumping well approximately $10 \mathrm{~km}$ away (SNJV, 2005).”

While active faults can act as conduits for flow, they may also act as barriers, particularly in alluvium. While positive head differences in geothermal areas drive hot, deep waters to the surface along basin-bounding faults, a negative head difference could also drive fluids down such a fault.

As shown in Figure 8-1, only three Mid- to Late-Quaternary-aged and younger fault zones exist within the NNSS. Two of those three young fault zones (Wahmonie and Rock Valley) occur in the vicinity of Frenchman Flat. The Rock Valley fault zone forms the southeast margin of Frenchman Flat and is the only fault in the NNSS with established Holocene-aged faulting (USGS, 2010). The 


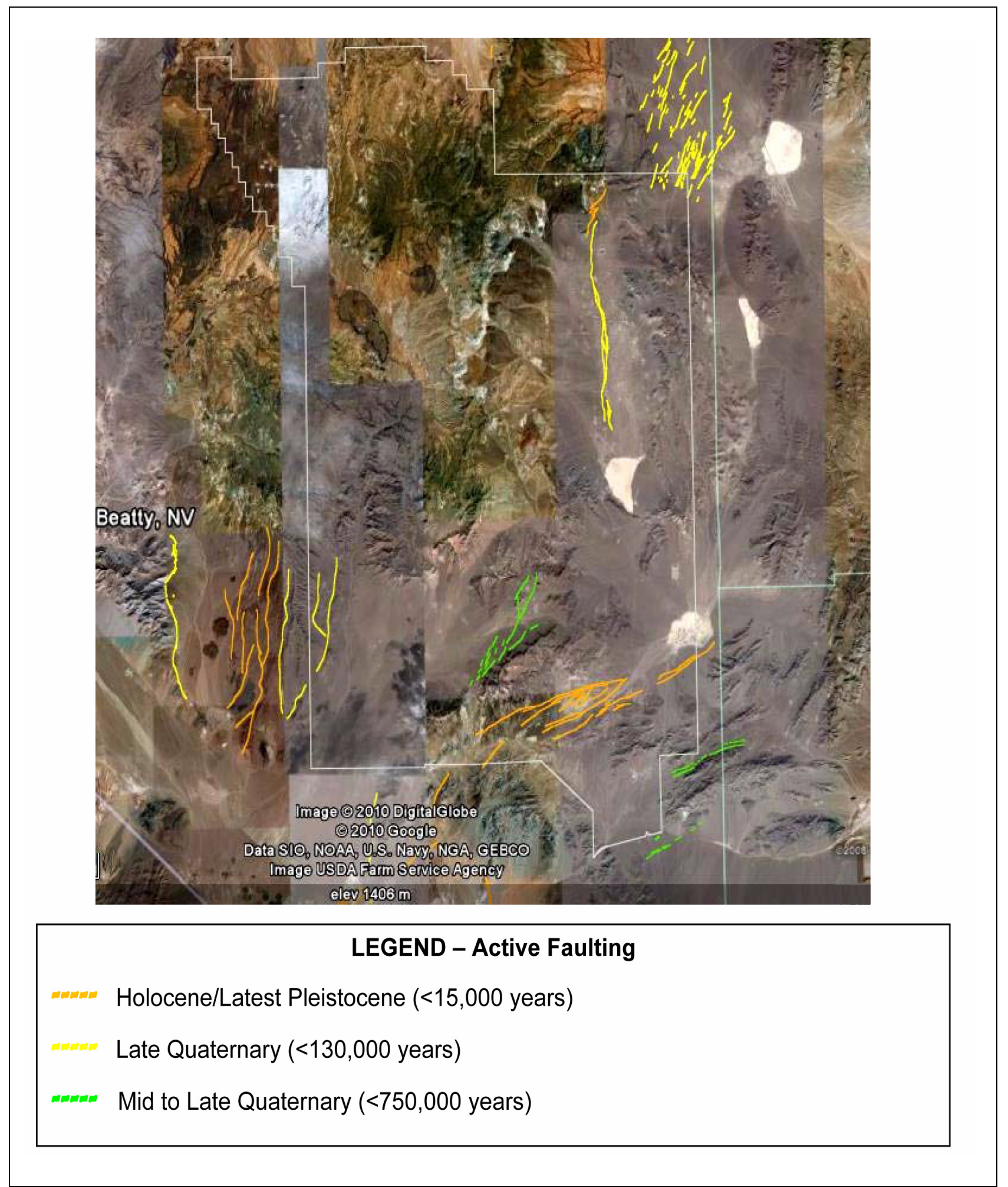

Figure 8-1

Late Quaternary Fault Map of the NNSS

Note: Faults are from the Quaternary Fault and Fold Database of the United States (USGS, 2010), and the NNSS is shown by a thin white line. 
Wahmonie fault is located only 3 to $4 \mathrm{~km}$ northwest of the Early Quaternary-age $(<1.6$ million year) Cane Spring fault that forms the northwest margin of Frenchman Flat (Figure 8-1).

The most up-to-date analysis of the seismicity and earthquake potential of the Frenchman Flat region was conducted as part of the Performance Assessment for the Area 5 RWMS, specifically in Addendum 2 (BN and Neptune, 2006). That report references a 1998 performance assessment that concluded that seismic activity was not a significant concern for the Area 5 RWMS within Frenchman Flat (Shott et al., 1998). The conclusion was based on the understanding that the return period for large (magnitude 5.8 or larger) earthquakes exceeded 10,000 years, and there was no evidence of recent faulting directly near the site (although late Holocene faulting was identified on the Rock Valley fault system $12 \mathrm{~km}$ south of the Area 5 RWMS).

In the next year, 1999, an earthquake sequence occurred in Frenchman Flat, with a magnitude 4.7 mainshock and a magnitude 4.2 foreshock. The events were 5 to $10 \mathrm{~km}$ deep with normal faulting focal mechanisms. This swarm was followed in 2002 by the magnitude 5.6 Little Skull Mountain earthquake in the southwesternmost part of the NNSS, approximately $20 \mathrm{~km}$ west of Frenchman Flat. The occurrence of these moderate events suggests a substantially higher seismicity rate than the initially assumed 10,000-year return period for magnitude 5.8 or larger earthquakes throughout the region concluded by Shott et al. (1998).

A paleoseismic investigation of the long Rock Valley fault zone in the alluvium of Frenchman Flat yielded a Quaternary/Holocene slip rate of 0.002 to 0.05 millimeters per year and a recurrence interval of 5,000 to 10,000 years, with a good deal of uncertainty (Coe et al., 1996). Studies associated with Yucca Mountain concluded that the Rock Valley fault zone could generate earthquakes of magnitude 7 or larger (O’Leary, 1996); this is based on a total potential fault length of about $50 \mathrm{~km}$.

The standard way to assess earthquake likelihood is the "so-called" Gutenberg-Richter law that expresses the power law relationship between the magnitude and total number of earthquakes in a given region and time period of at least that magnitude. It is typically expressed in a plot of the cumulative rate of occurrence of earthquake activity as a function of magnitude.

A Gutenberg-Richter plot for the NNSS region (Figure 8-2) was provided to the peer review team by Professor Ken Smith of the University of Nevada at Reno, head of seismic network operations for the 


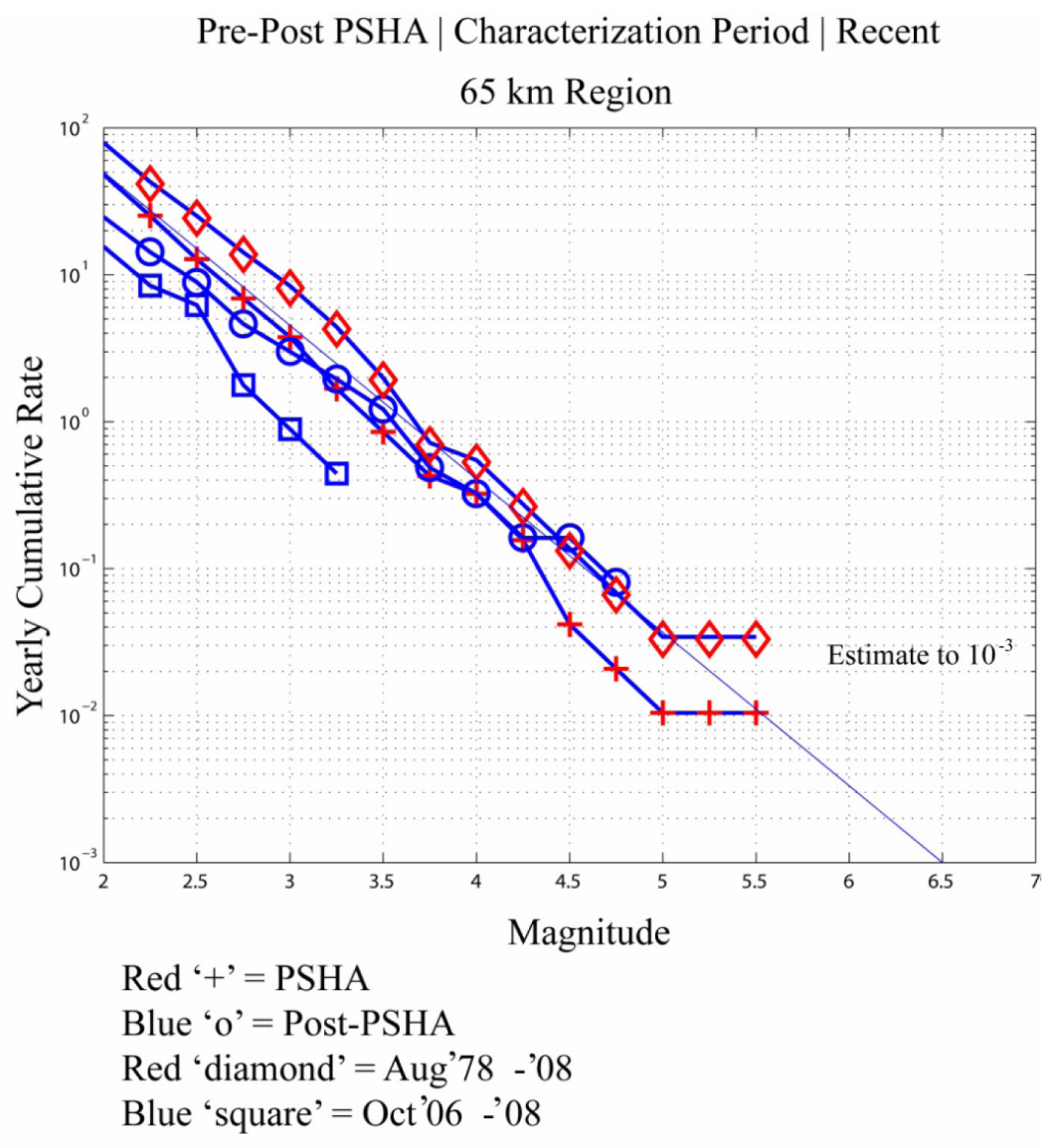

Figure 8-2

Gutenberg-Richter Plot of the Observed Rate of Earthquake Occurrence in the NNSS Region ${ }^{10}$

10. Data from four separate seismicity catalogs covering four different time periods are plotted. The first three catalogs listed are the most robust, with the Aug ' 78 - '08 catalog (red diamonds) representing the most complete instrumental coverage over the entire magnitude range sampled. Plot and extrapolation to higher magnitudes made for the 2009 University of Nevada, Reno, Yucca Mountain report and PC Test Plan, provided by Ken Smith, University of Nevada, Reno (Smith, 2010). Smith's hand-fit Gutenberg-Richter law indicates the occurrence of a magnitude 6.0 earthquake about once every 750 years, and a magnitude 6.5 earthquake once every 1,000 years.

Details on individual catalogs: The Probabilistic Seismic Hazard Analysis catalog (PSHA) was compiled for Yucca Mountain analysis and covers historic earthquakes (earliest in this region about 1916) through seismicity recorded up until August 31, 1996. The Post-PSHA catalog includes instrumental recordings from September 1, 1996 through December 31, 2008. The August '78 -'08 catalog is a composite of instrumental recordings from both the PSHA and Post-PSHA; this 30-year period is the formal Yucca Mountain Site Characterization Period and includes the notable seismic activity in the region in the late 1990s and early 2000s. The Oct '06 -'08 catalog represents the time period under Sandia Management. 
Southern Great Basin Seismic Network (Smith, 2010). The plot includes the rate of instrumentally recorded earthquakes through the end of 2008 as well as the occurrence of significant historic earthquakes in the vicinity of the NNSS. The Gutenberg-Richter relationship shown on the plot indicates that a magnitude 6 earthquake would be expected every 750 years and a magnitude 6.5 earthquake every 1,000 years in a region within $65 \mathrm{~km}$ of the NNSS.

The Rock Valley fault system is the only Holocene-aged fault zone identified in the NNSS (Figure 8-1). As noted previously, active microseismicity along the Rock Valley fault, including a magnitude 4.7 earthquake in 1999, indicates this fault zone is still active. Therefore, it seems likely that a moderate to large event in the 1,000-year regulatory time frame in the NNSS region might occur on the Rock Valley, or potentially on the Quaternary-aged Cane Spring fault.

Fracturing related to an earthquake rupture along either the Cane Spring or the Rock Valley fault zone could change permeability, particularly where the fault transects hard rocks. For example, such earthquake-induced fracturing along the Rock Valley fault could enhance the permeabilities of the volcanic confining units along this fault and provide potential enhanced pathways for groundwater flow into the LCA, particularly in areas where the confining units are interpreted to be very thin (approximately $100 \mathrm{~m}$ or less; e.g., along fault 33 just north of A-A' or along fault 21 just southeast of D-D'). Alternately, enhanced fracture permeability as a result of an earthquake along the Cane Spring fault system could modify the hydraulic connection between the CP basin and Frenchman Flat. The review team believes some scoping of the potential impact of such events should be part of the project team's analysis. 


\subsection{Recommendations}

The peer review team has unanimously agreed on a number of recommendations for future data collection and modeling evaluations in the Frenchman Flat CAU. These recommendations are described in the following sections.

\subsection{Recommendations on Monitoring in Next Stage}

The FFACO states that in the CADD/CAP stage, a monitoring design strategy will be implemented to "test model output and contaminant boundary forecasts through additional drill-hole exploration and focused testing and sampling” (FFACO, 1996; as amended March 2010).

It is the opinion of the peer review team that additional monitoring well installations and sampling will provide the most information useful for developing confidence in the calculated contaminant boundaries if the sampling results indicate a detect for a radiological contaminant. When designing a program for additional drill-hole exploration and sampling, it is essential that the design be based on the approximate 50-year contaminant boundaries and not the 1,000-year contaminant boundary, as the contaminated volume of groundwater represented by these boundaries represents the groundwater that is likely to be contaminated today.

Contaminant migration from all test locations in Frenchman Flat over the past 40 years has been quite limited because of the slow groundwater velocities in Frenchman Flat near the water table. Even if contaminant velocities for the most mobile of contaminants are on the order of $3 \mathrm{~m} / \mathrm{yr}$, radiological contamination is expected to occur within only approximately $120 \mathrm{~m}$ of the test locations today.

In designing a test program, it must also be recognized that the direction of groundwater flow in the immediate vicinity of the test locations is highly uncertain. Therefore, the probability is low that a nearby monitoring well will penetrate a zone with radiological contamination. 
The project team has proposed additional borings downgradient of the PIN STRIPE and MILK SHAKE test locations to develop better data to quantify the permeability, effective porosity, and continuity of the fractured volcanic units in the vicinity of these test locations. The peer review team has no objections to this proposal, as this information will potentially allow better estimates to be made of probable extent of contaminant migration in the fractured volcanic units.

The peer review team also supports the plan to use ground magnetic or low-level aeromagnetic surveys to delineate the subsurface extent of basalt flows in the alluvium in the Northern Testing Area. This will be potentially valuable in defining the eastward extent of the basalt unit, and also possibly the eastern extent of the east-west trending band of volcanic aquifer units, at least one of which is strongly magnetized.

\subsection{Recommendations on Water-Level Monitoring}

The peer review team is of the opinion that a groundwater monitoring program should be implemented to monitor water levels in key wells on a regular basis. The objectives of this monitoring are to determine long-term trends in water levels and to determine directions of groundwater flow. This monitoring program would be coordinated with the long-term quarterly monitoring of the pilot wells at the Area 5 RWMS. It is only because of the frequent monitoring of the pilot wells over more than a decade that reliable groundwater flow directions could be interpreted in such a low-flow-rate environment.

\subsection{Recommendations on Model Development}

The peer review team has identified several issues that should be addressed in the next phase of groundwater model revisions:

- Evaluating and using water-level gradients from the three pilot wells associated with the Area 5 RWMS in model calibration.

- Re-evaluating the use of geochemical age-dating data to constrain model calibrations.

- Developing water budgets for the alluvial and upper volcanic aquifer systems in Frenchman Flat. 
- Considering modeling approaches in which calculated groundwater flow directions near the water table are not predetermined by model boundary conditions and areas of recharge, all of which are very uncertain.

- Evaluating local-scale variations in hydraulic conductivity on the calculated contaminant boundaries, particularly within the alluvium.

- Evaluating the effects of non-steady-state flow conditions on calculated contaminant boundaries, including the effects of long-term declines in water levels; climatic change; and disruption of groundwater system by earthquake faulting of the two major controlling fault zones (Cane Spring and Rock Valley) in the flow system.

- Considering the use of less-complex modeling approaches.

- Evaluating large change in water levels between Wells WW-5C and WW-5B and developing a conceptual model to explain these water-level changes.

\subsection{Recommendations on Model Complexity}

Each member of the peer review team has been struck by the disparity between the number of subsurface data points (e.g., wells and their associated physical property data, water levels, and contaminant concentration measurements) and the complexity of the model calculations.

Considering the nature of the groundwater system at the NNSS, the types of contaminants involved, and the long-term nature of the potential contaminant plumes, the database seems unusually sparse (except at the CAMBRIC test location, where contaminant migration was observed during a 16-year migration experiment). On the other hand, the groundwater models created to predict future impacts are among the most complex the peer review team has ever seen. Even after about 10 weeks of study, team members do not fully understand all model calculations and the ramifications of model assumptions. It is inconceivable to peer review team members that any group of reviewers could ever fully appreciate the details of the modeling effort, given the large number of publications with thousands of pages of analyses generated by the Phase II team over the past 11 years, and the inability of the peer review team to make even one independent model simulation.

The peer review team has been asked to render an opinion as to whether the modeling is consistent with the state-of-the-practice. The team has not, however, been asked to address the suitability of the underlying data to inform the models and, ultimately, the regulatory decisions. The team feels 
compelled to offer an opinion on this topic in the hope that future modeling and data collection activities at the NNSS will be more compatible.

The NRC (2007), which has been cited numerous times in this report, summarizes the peer review team's concern on this issue:

"Models used in the regulatory process should be no more complicated than is necessary to inform regulatory decisions. In the process of evaluating whether a model is suitable for its given application, there should be a critical evaluation of whether the model has been made unreasonably complicated. This evaluation should include how model developers and those that select a model for a particular application have addressed the trade-offs between the need for a given model application to be an accurate representation of the system of interest and the need for it to be reproducible, transparent, and useful for the regulatory decision at hand."

Peer review team members have spent considerable time attempting to reconcile the actual field data with the model simulations. Because the Frenchman Flat basin has relatively little water-level and hydraulic property data, it was easier to evaluate than the modeling itself. The peer review team's views on the site data can be summarized as follows:

- Groundwater flow directions are difficult to infer from existing water-level data. However, the data do indicate that gradients are very flat in most areas.

- The only areas where precise groundwater flow directions can be computed with some confidence are at Wells UE-5 PW-1, UE-5 PW-2, and UE-5 PW-3. Groundwater velocities computed from these wells are consistent with model calculations, but the flow directions are not consistent with the models.

- The alluvial aquifer has few aquifer tests, but the limited data indicate the aquifer is only moderately permeable.

- The permeability and effective porosity of the fractured volcanic aquifers in the vicinity of PIN STRIPE and MILK SHAKE tests are poorly constrained.

- Groundwater ages are difficult to interpret. However, all age data show that the NNSS groundwater is thousands of years old.

- The geology is well understood.

In summary, the data indicate that groundwater is flowing very slowly but could be moving in directions ranging from east to southwest. The available data paint a very unclear picture of aquifer 
conditions at the NNSS, and yet quite elaborate and complex groundwater models have been built to make predictions of future contaminant boundaries. The data and the models do not seem to be of comparable detail.

In looking at the contaminant boundaries for the tests in alluvium, the peer review team believes that similar results could have been obtained using simpler modeling techniques. The NRC (2009) reached a similar conclusion when evaluating the complex groundwater modeling performed at Camp Lejeune, writing: "The committee recommends that simpler models be used instead of complex groundwater models. In particular, the use of conceptual models based on hydrogeologic characterization studies coupled with mass-balance calculations or analytic models should be given serious consideration ..."

Using very complex models creates the illusion of a precise answer and precludes a thorough review of the analysis. The 95 percent confidence limits also imply that the levels of uncertainty are well understood and characterized. In reality, the 95 percent confidence limits are a very detailed sensitivity analysis where only some of the potential uncertainties can ever be well known given the data limitations.

In the end, the models are used to make predictions that must then be tested through additional drilling programs in the monitoring phase. Using simpler models and analysis techniques would allow more time and budget for collecting better field data to confirm or refute these evaluations. 


\subsection{DOCUMENTS REVIEWED AND OTHER REFERENCES}

ASTM, see American Society for Testing and Materials.

American Society for Testing and Materials. 1994 (reapproved 2008). Standard Guide for

Conducting a Sensitivity Analysis for a Ground-Water Flow Model Application, ASTM D5611 94(2008). Philadelphia, PA.

BN, see Bechtel Nevada.

BN and Neptune, see Bechtel Nevada and Neptune and Company, Inc.

Barton, C.A., M.D. Zoback, and D. Moos. 1995. "Fluid Flow along Potentially Active Faults in Crystalline Rocks.” In Geology, Vol. 23, pp. 683-686.

Bechtel Nevada. 2005a. A Hydrostratigraphic Framework Model and Alternatives for the Groundwater Flow and Contaminant Transport Model of Corrective Action Unit 98: Frenchman Flat, Clark, Lincoln, and Nye Counties, Nevada, DOE/NV/11718--1064. Prepared for the U.S. Department of Energy, National Nuclear Security Administration Nevada Site Office. Las Vegas, NV.

Bechtel Nevada. 2005b. Completion Report for Well Cluster ER-5-3, DOE/NV/11718--1093. Prepared for the U.S. Department of Energy, National Nuclear Security Administration Nevada Site Office. Las Vegas, NV.

Bechtel Nevada. 2005c. Completion Report for Well Cluster ER-5-4, DOE/NV/11718--998. Prepared for the U.S. Department of Energy, National Nuclear Security Administration Nevada Site Office. Las Vegas, NV.

Bechtel Nevada. 2005d. "Northwest-Southeast Model Profile (D-D') at Well ER-5-4\#2." Las Vegas, NV.

Bechtel Nevada and Neptune and Company, Inc. 2006. Addendum 2 to the Performance Assessment for the Area 5 Radioactive Waste Management Site at the Nevada Test Site: Updated of Performance Assessment Methods and Results, DOE/NV/11718--176-ADD2. 
Belcher, W.R., J.B. Blainey, F.A. D’Agnese, C.C. Faunt, M.C. Hill, R.J. Laczniak, G.M. O’Brien, C.J. Potter, H.M. Putnam, C.A. San Juan, and D.S. Sweetkind. 2004. Death Valley Regional Ground-Water Flow System, Nevada and California - Hydrogeologic Framework and Transient Ground-Water Flow Model, Scientific Investigations Report 2004-5205. Reston, VA: U.S. Geological Survey.

Bowen, S.M., D.L. Finnegan, J.L. Thompson, C.M. Miller, P.L. Baca, L.F. Olivas, C.G. Geoffrion, D.K. Smith, W. Goishi, B.K. Esser, J.W. Meadows, N. Namboodiri, and J.F. Wild. 2001. Nevada Test Site Radionuclide Inventory, 1951-1992, LA-13859-MS. p. 18. Los Alamos, NM: Los Alamos National Laboratory.

Bright, D.J., S.A. Watkins, and B.A. Lisle. 2001. Analysis of Water Levels in the Frenchman Flat Area, Nevada Test Site, Water-Resources Investigations Report 00-4272. Denver, CO:

U.S. Geological Survey.

CFR, see Code of Federal Regulations.

Carle, S.F., R.M. Maxwell, G.A. Pawloski, D.E. Shumaker, A.F.B. Tompson, and M. Zavarin. 2007. Evaluation of the Transient Hydrologic Source Term for the Cambric Underground Nuclear Test at Frenchman Flat, Nevada Test Site, UCRL-TR-226916. Livermore, CA: Lawrence Livermore National Laboratory.

Castro, M.C., and P. Goblet. 2005. "Calculation of Ground Water Ages-A Comparative Analysis." In Ground Water, Vol. 43(3), pp. 368-380.

Code of Federal Regulations. 2009. Title 40 CFR Part 141, "National Primary Drinking Water Regulations." Washington, DC: U.S. Government Printing Office.

Coe, J.A., J.C. Yount, and D.W. O’Leary. 1996. "Preliminary Results of Paleoseismic Investigations of the Rock Valley Fault System, Nevada Test Site." In Seismotectonic Framework and Characterization of Faulting at Yucca Mountain, Nevada (J.W. Whitney [ed.]), Technical Report to the U.S. Department of Energy. Denver, CO: U.S. Geological Survey.

DOE/NV, see U.S. Department of Energy, Nevada Operations Office.

EPA, see U.S. Environmental Protection Agency.

Eberhart-Phillips, D., and D. Oppenheimer. 1984. "Induced Seismicity in the Geysers Geothermal Field, California." In Journal of Geophysics Research, Vol. 89, pp. 1191-1208.

Engesgaard, P., and J. Molson. 1998. "Direct Simulation of Ground Water Age in the Rabis Creek Aquifer, Denmark." In Ground Water, Vol. 36(4), pp. 577-582. 
FFACO, see Federal Facility Agreement and Consent Order.

Federal Facility Agreement and Consent Order. 1996 (as amended March 2010). Agreed to by the State of Nevada; U.S. Department of Energy, Environmental Management; U.S. Department of Defense; and U.S. Department of Energy, Legacy Management.

Feng, Q., and J.M. Lees. 1998. "Microseismicity, Stress, and Fracture in the Coso Geothermal Field, California." In Tectonophysics, Vol. 289, pp. 221-238.

GoldSim, see GoldSim Technology Group, LLC.

GoldSim Technology Group, LLC. 2006. User's Guide: GoldSim Graphical Simulation Environment, Version 9.5. Issaquah, WA.

Grauch, V.J.S., D.A. Sawyer, C.J. Fridrich, and M.R. Hudson. 1999. Geophysical Framework of the Southwestern Nevada Volcanic Field and Hydrogeologic Implications, Professional Paper 1608. Denver, CO: U.S. Geological Survey.

Helton, J.C. 1998. "Uncertainty and Sensitivity Analysis in Performance Assessment for the Waste Isolation Pilot Plant.” In Computer Physics Communications, Vol. 117, pp. 156-180.

Hershey, R.L., O. Dahan, S.C. Calhoun, and R. Jacobson. 2001. Geochemically Calibrated Discrete-State Cell Model of the Frenchman Flat Hydrographic Area.

Hershey, R.L., J.M. Thomas, T.P. Rose, J.B. Paces, I.M. Farnham, and F.C. Benedict, Jr. 2005. Evaluation of Groundwater Movement in the Frenchman Flat CAU Using Geochemical and Isotopic Analysis, DOE/NV/13609-36; Publication No. 45207. Prepared for the U.S. Department of Energy, National Nuclear Security Administration Nevada Site Office. Las Vegas, NV:

Desert Research Institute.

IT, see IT Corporation.

IT Corporation. 1999. External Peer Review Group Report on Frenchman Flat Data Analysis and Modeling Task, Underground Test Area Project, Rev. No. 0, ITLV/13052--077. Las Vegas, NV.

Laczniak, R.J., J. Cole, D.A. Sawyer, and D.A. Trudeau. 1996. Summary of Hydrogeologic Controls on Ground-Water Flow at the Nevada Test Site, Nye County, Nevada, Water Resources Investigations Report 96-4109. Carson City, NV: U.S. Geological Survey.

Los Alamos National Laboratory. 2001. Errata for Nevada Test Site Radionuclide Inventory, Bowen et al., LA-13859-MS. September.

Moore, J.E. 1962. Selected Logs and Drilling Records of Wells and Test Holes Drilled at the Nevada Test Site Prior to 1960, USGS-OFR-82-765 TEI-804. 54 p. Denver, CO: U.S. Geological Survey. 
NNES, see Navarro Nevada Environmental Services, LLC.

NRC, see National Research Council.

National Research Council. 2007. Models in Environmental Regulatory Decision Making. Committee on Models in the Regulatory Decision Process. 287 p. Washington, DC: National Academy Press.

National Research Council. 2009. Contaminated Water Supplies at Camp Lejeune: Assessing Potential Health Effect. 338 p. Washington, DC: National Academy Press.

Navarro Nevada Environmental Services, LLC. 2010a. Phase II Documentation Overview of Corrective Action Unit 98: Frenchman Flat, Nevada Test Site, Nye County, Nevada, Rev. 0, N-I/28091--007. Las Vegas, NV.

Navarro Nevada Environmental Services, LLC. 2010b. Phase II Transport Model of Corrective Action Unit 98: Frenchman Flat, Nevada Test Site, Nye County, Nevada, N-I/28091--004, S-N/99205--122. Las Vegas, NV.

Nimz, G.J., and J.L. Thompson. 1992. Underground Radionuclide Migration at the Nevada Test Site, DOE/NV-346. Las Vegas, NV: Reynolds Electrical \& Engineering Co., Inc.

Nygren, U., H. Ramebäck, and C. Nilsson. 2007. "Age Determination of Plutonium Using Inductively Coupled Plasma Mass Spectrometry." In Journal of Radioanalytical and Nuclear Chemistry, Vol. 272(1), 45-51.

O’Leary, D.W. 1996. “Tectontic Significance of the Rock Valley Fault Zone, Nevada Test Site.” In Seismotectonic Framework and Characterization of Faulting at Yucca Mountain, Nevada (J.W. Whitney [ed.]), Technical Report to the U.S. Department of Energy. Denver, CO: U.S. Geological Survey.

Poeter, E., and D. Anderson. 2005. "Multimodel Ranking and Inference in Ground Water Modeling." In Ground Water, Vol. 43, No. 4, pp. 597-605.

Parekh, P.P., T.M. Semkow, M.A. Torres, D.K. Haines, J.M. Cooper, P.M. Rosenberg, and M.E. Kitto. 2006. "Radioactivity in Trinitite Six Decades Later." In Journal of Environmental Radioactivity, Vol. 85, pp. 103-120.

SNJV, see Stoller-Navarro Joint Venture.

Shott, G. J., V. Yucel, M.J. Sully, L.E. Barker, S.E. Rawlinson, and B.A. Moore. 2000. Performance Assessment for the Area 3 Radioactive Waste Management Site at the Nevada Test Site, Nye County, Nevada, Rev. 2.1, DOE/NV--176-REV 2.1. Las Vegas, NV: Bechtel Nevada. 
Smith, K. 2010. Personal communication to M.L. Zoback containing Gutenberg-Richter plot of the observed rate of earthquake occurrence in the NTS Region, 24 May. Reno, NV: University of Nevada at Reno.

Smith, D.K., D.L. Finnegan, and S.M. Bowen. 2003. “An Inventory of Long-Lived Radionuclides Residual from Underground Nuclear Testing at the Nevada Test Site, 1951-1992." In Journal of Environmental Radioactivity, Vol. 67, pp. 35-51.

Stock, J.M., J.H. Healy, S.H. Hickman, and M.D. Zoback. 1985. "Hydrafracturing Stress Measurements at Yucca Mountain, Nevada and Relationship to the Regional Stress Field." In Journal of Geophysical Research, Vol. 90, pp. 8691-8706.

Stoller-Navarro Joint Venture. 2004a. Integrated Analysis Report for Single- and Multiple-Well Aquifer Testing at Frenchman Flat Well Cluster RNM-2s, Nevada Test Site, Nevada, S-N/99205--029. Las Vegas, NV.

Stoller-Navarro Joint Venture. 2004b. Interpretation of Hydraulic Test and Multiple-Well Aquifer Test Data at Frenchman Flat Well Cluster ER-5-3, S-N/99205--028. Las Vegas, NV.

Stoller-Navarro Joint Venture. 2004c. Phase II Hydrologic Data for the Groundwater Flow and Contaminant Transport Model of Corrective Action Unit 98: Frenchman Flat, Nye County, Nevada, S-N/99205-032. Las Vegas, NV.

Stoller-Navarro Joint Venture. 2005. Analysis of Hydraulic Responses from the ER-6-1 Multiple-Well Aquifer Test, Yucca Flat FY 2004 Testing Program, Nevada Test Site, Nye County, Nevada, Rev. 0, S-N/99205--051. Las Vegas, NV.

Stoller-Navarro Joint Venture. 2006. Phase II Groundwater Flow Model of Corrective Action Unit 98: Frenchman Flat, Nevada Test Site, Nye County, Nevada, S-N/99205-074, Rev. 0. Las Vegas, NV.

Tompson, A.F.B., C.J. Bruton, and G.A. Pawloski. 1999. Evaluation of the Hydrologic Source Term from the Underground Nuclear Tests in Frenchman Flat and the Nevada Test Site: The

CAMBRIC Test, UCRL-ID-132300. Livermore, CA: Lawrence Livermore National Laboratory.

Tonkin, M., and J. Doherty. 2009. “Calibration-Constrained Monte-Carlo Analysis of Highly Parameterized Models Using Subspace Methods.” In Water Resources Research, Vol. 45.

USGCRP, see United States Global Change Research Program.

USGS, see U.S. Geological Survey.

United States Global Change Research Program. 2009a. Global Climate Change Impacts in the United States. Available online at http://www.globalchange.gov/publications/reports/scientific-assessments/us-impacts. 
United States Global Change Research Program. 2009b. "Possible Future Climates.” In US National Assessment of the Potential Consequences of Climate Variability and Change Educational Resources Regional Paper: Rocky Mountain/Great Basin Region. Available online at http://www.usgcrp.gov/usgcrp/nacc/education/rockies-greatbasin/rockiesandgreatbasin-edu-2.htm\#Future.

U.S. Department of Energy, Nevada Operations Office. 1997. Regional Groundwater Flow and Tritium Transport Modeling and Risk Assessment of the Underground Test Area, Nevada Test Site, Nevada, DOE/NV--477. Las Vegas, NV.

U.S. Environmental Protection Agency. 2009. Guidance on the Development, Evaluation, and Application of Environmental Models, EPA/100/K-09/003. Washington, DC.

U.S. Geological Survey. 2010. Quaternary Fault and Fold Database of the United States. Available online at http://earthquake.usgs.gov/hazards/qfaults/.

Ward, P.L. 1972. "Microearthquakes: Possible Prospecting Tool and Potential Hazard in Geothermal Resources." In Geothermics, Vol. 1, pp. 3-12.

Winograd, I.J., and W. Thordarson. 1975. Hydrogeologic and Hydrochemical Framework, South Central Great Basin, Nevada-California, with Special Reference to the Nevada Test Site, Professional Paper 712-C. Denver, CO: U.S. Geological Survey.

Workman, J.B., C.M. Menges, W.R. Page, E.M. Taylor, E.B. Ekren, P.D. Rowley, G.L. Dixon, R.A. Thompson, and L.A. Wright. 2002. Geologic Map of the Death Valley Ground-Water Model Area, Nevada and California, U.S. Geologic Survey Misc. Field Studies Map MF 2381-A, scale 1:250,000. 
Appendix A

Bibliographic Information on Peer Review Team Members 


\section{A.1.0 Bibliographic INFORMATION on PeER ReVIEW TEAM MEMBERS}

Dr. Mary Lou Zoback is a geophysicist and seismologist who currently serves as Vice President for Earthquake Risk Applications at Risk Management Solutions in Newark, California. Before joining the company in 2006, she held a number of technical and management positions during a 28-year career with the USGS. In addition to her role as a senior scientist at USGS, she served as Chief Scientist of the Earthquake Hazards Team and Northern California Regional Coordinator for the Earthquake Hazard Program. She has served on numerous national committees and panels on topics ranging from defining the next generation of Earth observations from space, storage of high-level radioactive waste, facilitating interdisciplinary research, and science education. She is a member of the U.S. National Academy of Sciences, past President of the Geological Society of America, and currently a member of the Carnegie Foundation Board of Trustees and the Board of Directors of the Seismological Society of America. She chairs Advisory Committees for the Southern California Earthquake Center, the American Geologic Institute's Government Affairs Program, and the San Francisco's Department of Building Inspection's CAPSS (Citizens Action Plan for Seismic Safety) Program.

Dr. Chunmiao Zheng is professor of hydrogeology in the Department of Geological Sciences at the University of Alabama. He is also a visiting professor and founding director of the Center for Water Research at Peking University, China. The primary areas of his research are contaminant transport, groundwater management, and hydrologic modeling. Zheng is developer of the MT3D/MT3DMS contaminant transport models used in more than 100 countries, and is lead author of the textbook Applied Contaminant Transport Modeling published by Wiley in 1995 and 2002 and translated into Chinese in 2009. Zheng is recipient of the 1998 John Hem Excellence in Science and Engineering Award from the National Ground Water Association and a fellow of the Geological Society of America. In 2009, he received the Birdsall-Dreiss Distinguished Lecturer award from the Geological Society of America, which took him to 70 universities and research institutions worldwide. Zheng has served on numerous journal editorial boards and grant review panels. Currently, he is a member of the Standing Committee on Hydrologic Science of the National Research Council, a member of a National Academies panel to identify the major challenges and future opportunities in the field of hydrologic sciences, and President of the International Commission on Groundwater of the International Association of Hydrologic Sciences. Zheng holds a Ph.D. in hydrogeology with a minor in civil engineering from the University of Wisconsin-Madison.

Dr. Douglas D. Walker is a hydrologist with the Illinois State Water Survey, and a registered Professional Hydrologist. He earned a B.S. in watershed science (1983), an M.S. in civil engineering (1986), and a Ph.D. in agricultural engineering (1994), all from Colorado State University. He is the 
author or co-author of more than 60 publications and has more than 25 years experience conducting groundwater studies and evaluating waste repositories in Europe, Asia, and the United States. He is an Associate Editor of the journal Ground Water, and has been a member of the ASCE-EWRI committee on Ground Water Quality and the American Geophysical Union Groundwater Technical Committee. He has been awarded an AAAS Science and Technology Diplomacy Fellowship for 2010-2011.

James Rumbaugh is a hydrogeologist and groundwater modeler who has more than 25 years of experience in application of groundwater models and in development of groundwater modeling software tools. He is the co-author of the Groundwater Vistas software and is President of Environmental Simulations, Inc., a company that specializes in groundwater modeling. Jim is an active member of the ASTM, where he is a past Chairman of ASTM Subcommittee D18.21 on Groundwater and Vadose Zone Investigations. Subcommittee D18.21 was funded by EPA to develop standards for groundwater modeling practice. Jim was honored by the National Ground Water Association (NGWA) with the 1999 John Hem Excellence in Science and Engineering Award, which is given to those who have made a significant, recent scientific or engineering contribution to the understanding of groundwater. Jim teaches groundwater modeling seminars throughout the United States, Europe, Australia, and New Zealand. He has applied groundwater models to environmental problems throughout the United States, Canada, Europe, Australia, New Zealand, and Japan. His focus in recent years has been water-resource investigations in the western United States and Florida.

Dr. Ken Czerwinski has been actively engaged in radiochemistry research since 1987 . He is currently the Director of the Radiochemistry Ph.D. program at the University of Nevada, Las Vegas. His academic interests center on the chemistry of radioelements with an emphasis on the speciation and coordination of actinides and technetium compounds. His research areas include radioelement compound synthesis and characterization, separations of radioelements, nuclear forensics, and environmental radiochemistry.

Dr. Charles Andrews is President of S.S. Papadopulos \& Associates, Inc., a water-resource consulting firm based in Bethesda, Maryland. He has more than 30 years of experience in the development and use of groundwater models. 
Appendix B

Agenda for April 6-9, 2010, Meeting in Las Vegas

(5 Pages) 


\title{
The U.S. Department of Energy \\ Welcomes You To...
}

\author{
FRENCHMAN FLAT PEER REVIEW
}

April 6-9, 2010 - Las Vegas, NV

A G E N D A - April 6, 2010

\begin{tabular}{|c|c|c|}
\hline TIME & TOPIC & PRESENTER \\
\hline 0800-0830 & $\begin{array}{l}\text { Introductions / Agenda Review / } \\
\text { Meeting Norms } \\
\text { Introductory Remarks }\end{array}$ & $\begin{array}{l}\text { Carla Sanda, Facilitator } \\
\text { Consensus By Design } \\
\text { Stephen A. Mellington } \\
\text { National Nuclear Security Administration } \\
\text { Tim Murphy } \\
\text { Nevada Division of Environmental Protection } \\
\text { (NDEP) }\end{array}$ \\
\hline 0830-0915 & $\begin{array}{l}\text { Introduction to EM and UGTA / } \\
\text { Regulatory Perspectives }\end{array}$ & $\begin{array}{l}\text { Rob Boehlecke, US Department of Energy } \\
\text { Bill Wilborn, US Department of Energy } \\
\text { Chris Andres, NDEP } \\
\text { Bruce Crowe, NNES }\end{array}$ \\
\hline 0915-0945 & Frenchman Flat Overview & Greg Ruskauff, NNES \\
\hline 0945-1000 & B REAK & \\
\hline $1000-1100$ & $\begin{array}{l}\text { Frenchman Flat Underground } \\
\text { Nuclear Testing }\end{array}$ & $\begin{array}{l}\text { Andy Tompson } \\
\text { Lawrence Livermore National Laboratory } \\
\text { (LLNL) }\end{array}$ \\
\hline $1100-1200$ & $\begin{array}{l}\text { Geologic Setting / } \\
\text { Hydrostratigraphic Description / } \\
\text { Hydrostratigraphic Framework }\end{array}$ & $\begin{array}{l}\text { Sig Drellack and Lance Prothro, } \\
\text { National Securities Technologies (NSTec) }\end{array}$ \\
\hline $1200-1315$ & LUNCH & \\
\hline $1315-1415$ & Geologic Setting - cont'd & Sig Drellack and Lance Prothro (NSTec) \\
\hline $1415-1430$ & B REAK & \\
\hline $1430-1530$ & Hydrogeologic Conceptual Model & $\begin{array}{l}\text { Ed Kwicklis, Los Alamos National Lab (LANL) } \\
\text { Greg Ruskauff, NNES }\end{array}$ \\
\hline $1530-1545$ & B REAK & \\
\hline $1545-1645$ & $\begin{array}{l}\text { Hydrologic Conceptual Model - } \\
\text { continued }\end{array}$ & \\
\hline $1645-1700$ & Wrap-Up / Preview Day Two & Carla Sanda, Facilitator \\
\hline
\end{tabular}


FRENCHMAN FLAT PEER REVIEW FIELD TRIP

April 7, 2010 - Las Vegas, NV

I T I N E R A R Y

\begin{tabular}{|c|c|c|}
\hline TIME & STOP & TOPIC \\
\hline $0715-0730$ & & Board bus at Hampton Inn; depart for Nevada Test Site \\
\hline 0845 & 1 & $\begin{array}{l}\text { US Geological Survey Core Library } \\
\text { - Orientation } \\
\text { - View / discuss core samples }\end{array}$ \\
\hline 0930 & 2 & $\begin{array}{l}\text { Frenchman Flat overlook } \\
\text { - General discussion; view observation bleachers used during } \\
\text { above-ground testing }\end{array}$ \\
\hline 0945 & 3 & $\begin{array}{l}\text { Frenchman Playa } \\
\qquad \quad \text { View / discuss relics of historic above-ground testing }\end{array}$ \\
\hline 1015 & 4 & $\begin{array}{l}\text { Central Test Area } \\
\text { - Underground Test Area (UGTA) Well ER-5-4 }\end{array}$ \\
\hline 1045 & 5 & $\begin{array}{l}\text { CAMBRIC Test (U-5E) } \\
\text { - Well RNM\#2S and CAMBRIC Ditch }\end{array}$ \\
\hline 1115 & 6 & Well UE-5n \\
\hline 1145 & 7 & CAMBRIC Ditch discharge point on to Frenchman Playa \\
\hline & & L U N C H \\
\hline 1300 & 8 & Wishbone (U-5a) surface collapse crater \\
\hline 1330 & 9 & $\begin{array}{l}\text { Northern Test Area } \\
\qquad \quad \text { UGTA Well ER-5-3 }\end{array}$ \\
\hline 1400 & 10 & Pinstripe Test (U-11b) and volcanic units in the hills to the north \\
\hline 1530 & 11 & $\begin{array}{l}\text { Southern Massachusetts Mountain } \\
\text { - Wahmonie lava flow; nearby outcrop; structure in northern } \\
\text { Frenchman Flat }\end{array}$ \\
\hline 1630 & 12 & $\begin{array}{l}\text { CP Hogback } \\
\quad \text { Yucca Flat; CP Basin; Frenchman Flat overlook }\end{array}$ \\
\hline $1700-1830$ & & Travel from Nevada Test Site to Hampton Inn \\
\hline
\end{tabular}




\section{The U.S. Department of Energy}

Welcomes You To...

FRENCHMAN FLAT PEER REVIEW

April 6-9, 2010 - Las Vegas, NV

A G E N D A - April 8, 2010

\begin{tabular}{|c|c|c|}
\hline TIME & TOPIC & PRESENTER \\
\hline 0800-0815 & $\begin{array}{l}\text { Welcome / Agenda Review / } \\
\text { Tour Follow-Up Questions }\end{array}$ & Carla Sanda, Facilitator \\
\hline 0815-0930 & Corrective Action Unit (CAU) Flow Model & $\begin{array}{l}\text { Nicole DeNovio, NNES } \\
\text { Ed Kwicklis,LANL } \\
\text { Greg Ruskauff, NNES }\end{array}$ \\
\hline 0930-0945 & B REAK & \\
\hline 0945-1100 & $\begin{array}{l}\text { Corrective Action Unit (CAU) Flow Model - } \\
\text { continued }\end{array}$ & \\
\hline $1100-1115$ & B REAK & \\
\hline $1115-1200$ & Unclassified Radiological Source Term & $\begin{array}{l}\text { Andy Tompson, LLNL } \\
\text { Mavrik Zavarin, LLNL }\end{array}$ \\
\hline $1200-1315$ & $\mathrm{LUNCH}$ & \\
\hline $1315-1445$ & CAMBRIC Hydrologic Source Term & Andy Tompson, LLNL \\
\hline $1445-1500$ & B REAK & \\
\hline $1500-1645$ & CAMBRIC Hydrologic Source Term - continued & Andy Tompson, LLNL \\
\hline $1645-1700$ & Wrap-Up / Discussion & Carla Sanda, Facilitator \\
\hline
\end{tabular}




\section{The U.S. Department of Energy}

\section{Welcomes You To...}

\section{FRENCHMAN FLAT PEER REVIEW}

April 6-9, 2010 - Las Vegas, NV

A G E N D A - April 9, 2010

\begin{tabular}{|c|c|c|}
\hline TIME & TOPIC & PRESENTER \\
\hline 0800-0805 & Agenda Review / Questions & Carla Sanda, Facilitator \\
\hline $0805-1000$ & Central Testing Area Model & Ed Kwicklis, LANL \\
\hline $1000-1015$ & BREAK & \\
\hline $1015-1115$ & Model Evaluation & $\begin{array}{l}\text { Nicole DeNovio, NNES } \\
\text { Ed Kwicklis, LANL } \\
\text { Greg Ruskauff, NNES }\end{array}$ \\
\hline $1115-1130$ & B REAK & \\
\hline $1130-1230$ & CAU Source Term Models & $\begin{array}{l}\text { Peter Martian, NNES } \\
\text { Greg Ruskauff, NNES }\end{array}$ \\
\hline $1230-1315$ & L U N CH & \\
\hline $1315-1415$ & CAU Source Term Models - continued & \\
\hline $1415-1430$ & B REAK & \\
\hline $1430-1530$ & Transport Model & $\begin{array}{l}\text { Nicole DeNovio, NNES } \\
\text { Ed Kwicklis, LANL } \\
\text { Greg Ruskauff, NNES }\end{array}$ \\
\hline $1530-1545$ & BREAK & \\
\hline $1545-1600$ & Monitoring Concepts & Sam Marutzky, NNES \\
\hline $1600-1615$ & Summary & $\begin{array}{l}\text { Bruce Crowe, NNES } \\
\text { Greg Ruskauff, NNES }\end{array}$ \\
\hline $1615-1700$ & Path Forward & Carla Sanda, Facilitator \\
\hline
\end{tabular}




\section{The U.S. Department of Energy}

\section{Welcomes You To...}

FRENCHMAN FLAT PEER REVIEW

April 6-9, 2010 - Las Vegas, NV

PRESENTERS(P) / ATTENDEES(A)

\section{AFFILIATION}

Nevada Division of Environmental Protection

National Nuclear Security Administration (NNSA) /

Nevada Site Office (NSO)

Navarro Nevada Environmental Services (NNES)

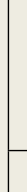

Lawrence Livermore National Laboratory (LLNL)

\begin{tabular}{|l}
\hline Los Alamos National Laboratory (LANL) \\
\hline National Securities Technologies (NSTec) \\
\hline Desert Research Institute (DRI) \\
\hline US Geological Survey \\
\hline
\end{tabular}

Tim Murphy (P) Chris Andres ( $P$ )

Stephen A. Mellington ( $P$ ) Rob Boehlecke $(P)$ Bill Wilborn $(P)$

Dave Taylor (A) Sam Marutzky $(P)$ Bruce Crowe (P) Greg Ruskauff (P) Nicole DeNovio $(P)$ Peter Martian (P) Joe Johnston (A) Andy Tompson (P) Mavrik Zavarin (P) Walt McNab (A) Gayle Pawloski (A) Ed Kwicklis (P) Naomi Becker (A)

Sig Drellack (P) Lance Prothro $(P)$ Ken Ortego (A) Chuck Russell $(A)$ Bonnie Thompson (A) 


\section{DISTRIBUTION}

\section{$\underline{\text { Copies }}$}

W.R. Wilborn

Environmental Restoration Project

6 hard copies w/electronic media

U.S. Department of Energy

National Nuclear Security Administration

Nevada Site Office

P.O. Box 98518, M/S 505

Las Vegas, NV 89193-8518

K.C. Thompson

Environmental Restoration Project

U.S. Department of Energy

National Nuclear Security Administration

Nevada Site Office

P.O. Box 98518, M/S 505

Las Vegas, NV 89193-8518

Bimal Mukhopadhyay

Environmental Restoration Project

U.S. Department of Energy

National Nuclear Security Administration

Nevada Site Office

P.O. Box 98518, M/S 505

Las Vegas, NV 89193-8518

Bruce Crowe

Navarro-Intera, LLC

P.O. Box 98952, MS 505

Las Vegas, NV 89193-8518

U.S. Department of Energy

Office of Scientific and Technical Information

1 electronic media

P.O. Box 62

Oak Ridge, TN 37831-0062

U.S. Department of Energy

1 electronic media

1 electronic media

National Nuclear Security Administration

Nevada Site Office

Technical Library

P.O. Box $98518, \mathrm{M} / \mathrm{S} 505$

Las Vegas, NV 89193-8518

1 electronic media

1 electronic media 


\section{$\underline{\text { Copies }}$}

Celeste Sandoval

1 electronic media

Nye County

Nuclear Waste Repository Project Office

1210 E. Basin Road, Suite \#6

Pahrump, NV 89060

Naomi Becker

1 electronic media

Los Alamos National Laboratory

Hydrology, Geochemistry, and Geology Group, EES-6

Earth and Environmental Sciences Division

Bikini Atoll Rd., SM30, MS T003

Los Alamos, NM 87545

Sam Marutzky

Navarro-Intera, LLC

P.O. Box 98952, NSF 167

Las Vegas, NV 89193-8518

Walt McNab

Lawrence Livermore National Laboratory

1 electronic media

7000 East Avenue, L-530

Livermore, CA 94550-9909

Ken Ortego

1 electronic media

National Security Technologies, LLC

P.O. Box 98521, M/S NLV 082

Las Vegas, NV 89193-8521

Chuck E. Russell

1 electronic media

Desert Research Institute

755 E. Flamingo

Las Vegas, NV 89119

Bonnie Thompson

1 hard copy w/electronic media

U.S. Geological Survey

Water Resources Division

160 North Stephanie Street

Henderson, NV 89074

Ed Kwicklis

Los Alamos National Laboratory

1 electronic media

Hydrology, Geochemistry, and Geology Group, EES-6

Earth and Environmental Sciences Division

SM-30 Bikini Atoll Rd., MS T003

Lo Alamos, NM 87545

1 electronic media 


\section{$\underline{\text { Copies }}$}

Gayle Pawloski

Lawrence Livermore National Laboratory

7000 East Avenue, L-231

Livermore, CA 94550-9900

Greg Ruskauff

Navarro-Intera , LLC

P.O. Box 98952, NSF 167

Las Vegas, NV 89193-8518

Nicole DeNovio

Golder Associates Inc.

18300 NE Union Hill Road, Suite 200

Redmond, Washington 98052

Southern Nevada Public Reading Facility

c/o Nuclear Testing Archive

P.O. Box 98521, M/S NLV 400

Las Vegas, NV 89193-8521

Northern Nevada Public Reading Facility c/o Nevada State Library \& Archives

100 N Stewart Street

Carson City, NV 89701-4285

Environmental Management Records

U.S. Department of Energy

National Nuclear Security Administration

Nevada Site Office

P.O. Box $98518, \mathrm{M} / \mathrm{S} 505$

Las Vegas, NV 89193-8518

NNSA/NSO, Read File

U.S. Department of Energy

National Nuclear Security Administration

Nevada Site Office

P.O. Box 98518, NSF 161

Las Vegas, NV 89193-8518

Navarro-Intera, LLC

Central Files

P.O. Box 98952, NSF 156

Las Vegas, NV 89193-8518
1 electronic media

1 electronic media

1 electronic media

2 electronic media

1 electronic media

1 hard copy w/electronic media

1 electronic media

1 hard copy w/electronic media 